THE ROLE OF CANADIAN NATIONAL PRINT MEDIA IN FOSTERING POSITIVE PUBLIC OPINION TOWARDS THE LEGISLATION OF SAME-SEX MARRIAGE IN CANADA

by

Amanda Piche

Master of Arts, Ryerson University and York University, 2014

Bachelor of Education, Laurentian University, 2012

Bachelor of Arts, Laurentian University, 2011

A dissertation

presented to Ryerson University and York University

in partial fulfillment of the

requirements for the degree of

Doctor of Philosophy

in the program of

Communication and Culture

Toronto, Ontario, Canada, 2020

(C) Amanda Piche, 2020 


\section{AUTHOR'S DECLARATION FOR ELECTRONIC SUBMISSION OF A DISSERTATION}

I hereby declare that I am the sole author of this dissertation. This is a true copy of the dissertation, including any required final revisions, as accepted by my examiners.

I authorize Ryerson University to lend this dissertation to other institutions or individuals for the purpose of scholarly research.

I further authorize Ryerson University to reproduce this dissertation by photocopying or by other means, in total or in part, at the request of other institutions or individuals for the purpose of scholarly research.

I understand that my dissertation may be made electronically available to the public. 


\title{
THE ROLE OF CANADIAN NATIONAL PRINT MEDIA IN FOSTERING POSITIVE PUBLIC OPINION TOWARDS THE LEGISLATION OF SAME-SEX MARRIAGE IN CANADA
}

\author{
Doctor of Philosophy, 2020 \\ Amanda Piche \\ Communication and Culture \\ Ryerson University and York University
}

\begin{abstract}
Since the Charter of Rights and Freedoms emerged in 1982, Canadian national print news was central to the complex networks in the establishment of same-sex marriage in 2005. Newspapers framed marriage equality as a human rights' issue, within conventions for balance and objectivity. However, LGBTQrelated issues have not consistently been approached this way by the media, which have traditionally created and regulated boundaries of gender and sexuality (Rubin 2007). This dissertation explores why Canadian mainstream press oscillated between anti-queer and pro-LGBTQ approaches in a post-Charter Canada and its effect on public opinion.

I show how news reporting is symbiotically implicated in Canadian public perspectives through public sphere theory (Habermas 1989; Fraser 1992). Frame analysis demonstrates how the issue was ideologically positioned in print (Goffman, 1974; Entman 1993; McCombs 2004; Scheufele 1999, 2000). A content analysis of over 2,000 national newspaper articles published between 1982 and 2005 reveal the frames used in stories about marriage equality. Semi-structured interviews with journalists and activists contextualize the analysis. Responses determine how media frames may have implicated understanding and support of the issue, and why and how certain frames were decided by journalists.

This work informs the history of LGBTQ rights in Canada by exploring how the national news industry contributed to the framing of marriage equality. Analyses of news coverage of marriage equality remains largely US-centric (Brewer 2002 \& 2003; Tadlock, et. al, 2007; Liebler et al., 2009; Li and Liu, 2010; Pan et al. 2010). Research on framing marriage equality in Canada focuses on litigants (Smith 2007), courts (Matthews 2005), and newspapers in 2003 and 2004 (Bannerman 2012). Despite several studies concerning the politics of sexual diversity in Canada (Hogg 2006; Kinsman 1996; Kinsman and Gentile 2010; Pettinicchio 2010; Rayside 2008; M. Smith 2008, 2012), marriage equality has not been studied extensively.
\end{abstract}




\section{Acknowledgements}

I cannot begin to express my thanks to my supervisor, Art Blake, for his profound belief in my work and his unrelenting support throughout the entirety of my doctoral studies. I also wish to thank the other members of my committee, Paul Moore and Anne MacLennan, for their thoughtful and constructive feedback during each stage of the dissertation process. I am deeply indebted to all members of my committee for sharing their expertise and time with me. Thanks to their guidance, I've grown as a scholar, becoming more confident in my abilities and voice. I'd like to thank both past and present Program Directors (Paul Moore, Jeremy Shtern) and Program Administrators (Jo Ann Mackie, Sarah Edmonds) of the Communication and Culture program for their support and assistance.

I gratefuly acknowledge the support I received from the Social Sciences and Humanities Research Council of Canada and the Edward S. Rogers Sr. Graduate School Fellowship. This research would not have been possible without their support.

Many thanks to the staff and volunteers at the The ArQuives - Canada's LGBTQ2+ archives who worked diligently to help me access some of the primary source material that was integral to this dissertation.

I would like to extend my sincere thanks to the participants who shared their time and insights with me. This dissertation could not exist without their voices, and I am so grateful for their involvement and trust in me.

Finally, I must thank my family and friends for their encouragement and patience throughout the past several years. Their unfaltering belief in me has fuelled me throughout my studies! A special thank you to my Shih Tzu, Keeper, for providing me with an endless supply of comfort as he watched me write much of this dissertation! 


\section{Dedication}

I dedicate my dissertation to my parents Mary Anne and Norm Piche, and my best friends, Cindy Wong and Amanda Lalonde. 


\section{Table of Contents}

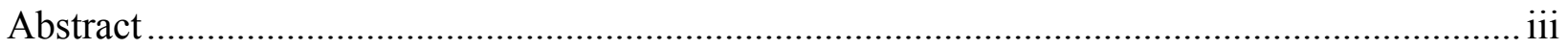

Acknowledgements ........................................................................................................... iv

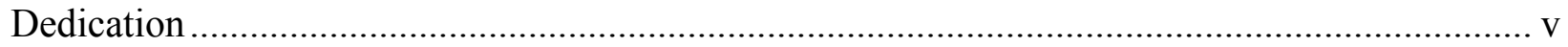

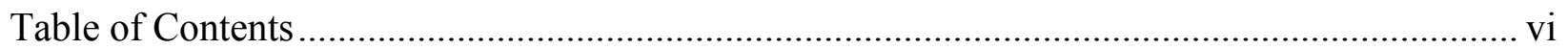

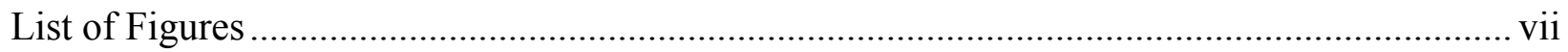

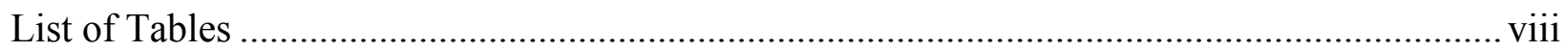

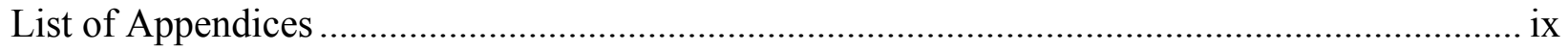

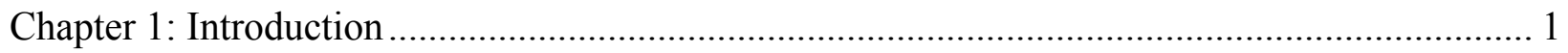

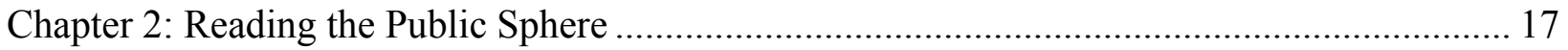

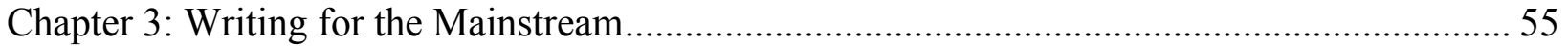

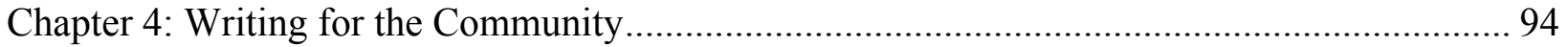

Chapter 5: Conclusions, Discussion, and Suggestions for Future Research............................... 129

Appendix A: Marriage Equality in Canada Timeline …………............................................... 139

Appendix B: Dissertation Coding Schedule and Coding Protocol ............................................. 141

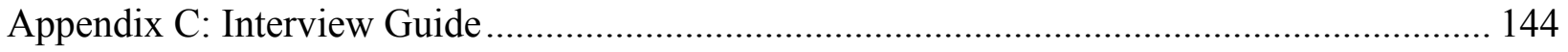

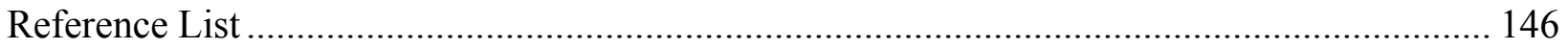




\section{List of Figures}

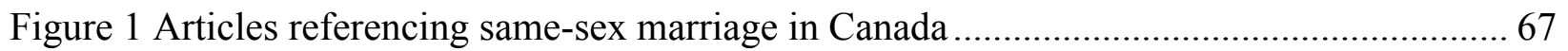

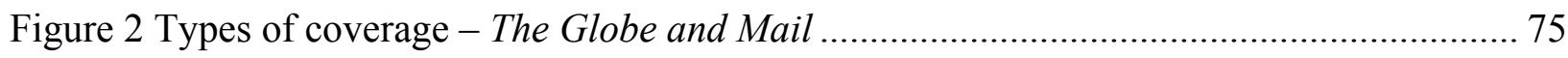

Figure 3 Types of coverage - National Post …………………............................................. 75 


\section{List of Tables}

Table 1 Framing type differences between The Globe and Mail and the National Post ............. 76

Table 2 Presence of framing type by article type ................................................................. 78 


\section{List of Appendices}

Appendix A: Marriage Equality in Canada Timeline

Appendix B: Dissertation Coding Schedule and Coding Protocol

Appendix C: Interview Guide 


\section{Chapter 1: Introduction}

Mounted in the Canadian Museum for Human Rights in Winnipeg, Manitoba is Chris Vogel and Rich North's wedding certificate. The couple exchanged vows on February $11^{\text {th }}$, 1974, during their wedding ceremony at the Unitarian Universalist Church of Winnipeg. The proclamation of the banns - a Christian tradition of publishing or giving public notice of people's intent to marry - was used by the church as a means to circumvent the Canadian marriage laws that restricted marriage to heterosexual couples. Their efforts to wed were initially denied in late1973, when the couple were refused a marriage license by the province; however, they were made aware by the clergyman who would eventually marry them of an alternative. Vogel and North's was the first same-sex marriage ceremony performed in the province of Manitoba and the second in Canada; Michel Girouard and Réjean Tremblay, a Montreal-based couple, were married in 1972. Like Vogel and North, Girouard and Tremblay utilized marriage as a political act meant to confront homosexual oppression. Under Quebec's Civil Code, an entertainment lawyer was able to draw up a contract for a legal partnership that both merged their business careers and bonded them together in a mutually supportive partnership. Despite being unable to find a priest or minister to officiate their marriage-like ceremony and being refused a blessing of their union by the Roman Catholic Church, they pushed on; the ceremony, attended by both guests and the media, was held at popular gay club Chez ZouZou. ${ }^{1}$

Despite agreeing with the voices of many within the gay liberation movement at the time that marriage was an unequal relationship that reinforced traditional gender roles and patriarchal attitudes, Vogel and North were motivated to marry in an effort to fight the prejudice and

\footnotetext{
${ }^{1}$ See: Elise Chenier, "Liberating Marriage: Gay Liberation and Same-Sex Marriage in Early 1970s Canada," in We StilL Demand! Redefining Resistance in Sex and Gender Struggles, eds. Patrizia Gentile et al. (Vancouver: UBC Press, 2017), 33-36; Unknown, "News of the Gay," The Body Politic, March/April 1972, 9; CP, "Homosexual Pair Become Partners in Public, Private," The Globe and Mail, February 28, 1972, 9.
} 
discrimination against homosexuals that existed in the nation. ${ }^{2}$ Aware of the implications that marriage restrictions had on the psyche and morale of homosexuals, Vogel and North wanted their marriage to suggest to others that it was possible to have a publicly recognized relationship, in the process equalizing homosexual and heterosexual relationships. ${ }^{3}$ Knowing their wedding ceremony would capture the attention of the media, the couple knew they would have a platform to educate the public on the realities of homosexual relationships - that gay people fall in love and engage in long-term, stable relationships the same way heterosexual couples do. ${ }^{4}$ They also recognized they would be setting a precedent of legal importance.

Although Vogel and North were in receipt of a wedding certificate and applied for their marriage to be registered, the registrar refused to do so. The couple took the public servant to court, with the trial taking place in October 1974; ultimately, the judgment relied on dictionary definitions of marriage to uphold that marriage could only take place between a man and a woman. North states that, given that their legal fight took place prior to the existence of the Canadian Charter of Rights and Freedoms, there was no legal foundation for supporting the marriage, and thus, no legal recourse to respond to this. ${ }^{5}$ Subsequently, that ended their battle for a time.

In 2004, when the province of Manitoba was ordered to begin issuing marriage licenses to same-sex couples, Vogel and North saw no need to remarry, for they considered themselves married for thirty years ${ }^{6}$; however, their marriage was never registered with the vital statistics

\footnotetext{
${ }^{2}$ Barbara Frum, "Gay Winnipeg Couple Marries," As It Happens, February 21, 1974, https://www.cbc.ca/archives/entry/gay-winnipeg-couple-marries.

${ }^{3}$ Ibid.

${ }^{4}$ Ibid.

5 Nancy Nicol, "Interview with Chris Vogel and Richard North (2004), as they discuss their marriage in 1974," The ArQuives, accessed November 18'2018, https://vimeo.com/193923100.

${ }^{6}$ CBC News, "Same-sex Winnipeg couple won't quit fight to have 1974 marriage recognized," $C B C$, February 15, 2018, https://www.cbc.ca/news/canada/manitoba/same-sex-winnipeg-couple-won-t-quit-fight-tohave-1974-marriage-recognized-1.4537406.
} 
bureau in Manitoba. The couple decided that the province should retroactively recognize their union in an effort to demonstrate their support for their marriage; the couple took their complaint to the Manitoba Human Rights Commission in December 2015. ${ }^{7}$ Adjudicator Robert Dawson revealed his decision in January 2018, noting that despite the evolution in marriage laws in the nation, as human rights adjudicator, he had no right to overturn the judge's decision from 1974; he did, however, urge the couple to take further action. ${ }^{8}$ Motivated to continue their fight for symbolic and legal reasons rather than get married under current laws, Vogel and North applied for judicial review, which was filed with the Court of Queen's Bench in Winnipeg on February $14^{\text {th }}, 2018$, with their return to the courts beginning March $6^{\text {th }}, 2018 .^{9}$

This was certainly not the last attempt to utilize the proclamation of the banns in order to challenge the existing institutionalization of marriage in Canada; indeed, an attempt made nearly thirty years after Vogel and North's efforts had a powerful effect on the fight for marriage equality in the nation. On January 14, 2001, Reverend Brent Hawkes performed two same-sex marriages - those of Kevin Bourassa and Joe Varnell and Anne and Elaine Vautour - at the Metropolitan Community Church of Toronto through the proclamation of banns of marriage; over 1000 people attended the service, including 70 media outlets. The subsequent refusal by Bob Runciman, Solicitor General and Registrar of Ontario, to accept the records of their marriage prompted the initiation of a court case; on January 19, 2001 MCC Toronto received official notice of the refusal, and swiftly filed legal action in Divisional Court. The following

\footnotetext{
${ }^{7}$ CBC News, "Chris Vogel, Richard North fight for Manitoba to recognize 41-year same-sex marriage," $C B C$, February 18, 2018, https://www.cbc.ca/news/canada/manitoba/chris-vogel-richard-north-fight-for-manitobato-recognize-41-year-same-sex-marriage-1.2961152.

${ }^{8}$ Elisha Dacey, "Failing to register 1974 same-sex marriage not discriminatory: Manitoba human rights adjudicator," $C B C$, January 10, 2018, https://www.cbc.ca/news/canada/manitoba/failing-register-1974-same-sexmarriage-not-discriminatory-1.4480879.

${ }^{9}$ CBC News, "Same-sex Winnipeg couple won't quit fight to have 1974 marriage recognized," $C B C$, February 15, 2018, https://www.cbc.ca/news/canada/manitoba/same-sex-winnipeg-couple-won-t-quit-fight-tohave-1974-marriage-recognized-1.4537406.
} 
month, the Divisional Court of Ontario joined the MCC Toronto case with a civil case representing seven couples denied marriage licenses by the City of Toronto (including Hedy Halpern and Colleen Rogers, and Michael Leshner and Michael Stark) that was launched the previous Spring. The Divisional Court heard their case - Halpern v. Canada - in November 2001, with the Ontario Superior Court of Justice handing down a landmark decision on July 12 , 2002 in favour of the right to conduct and register same-sex marriages; the Ontario Superior Court ruled that the federal definition of marriage as a union between one man and one woman was a violation of equality rights under the Charter of Rights and Freedoms. Over two weeks later, the Minister of Justice and Attorney General of Canada announced that the Government of Canada would seek leave to appeal the July $12^{\text {th }}$ ruling; ultimately, on June 10,2003 , the Ontario Court of Appeal upheld the Superior Court Decision in favour of same-sex marriages, effective immediately. A week later, Prime Minister Jean Chretien announced that the federal government would work to legalize same-sex marriages in the nation.

These narratives offer a point of departure to begin introducing the aims of this dissertation. First, they indicate that the bid for marriage equality has a long-standing place in the history of LGBTQ activism in Canada; gay men and lesbians have fought passionately for the right to marry, holding strong that their relationships deserved legal legitimacy. That said, one cannot overlook the impact of the 1982 Charter of Rights and Freedoms, the powerful legal tool used by activists to drive this legitimization. Indeed, according to sexuality studies scholar David Rayside, the advancement of LGBTQ rights in the nation "... has a great deal to do with the leverage provided by the Charter of Rights and Freedoms and by the preparedness of the judiciary to apply it to lesbian/gay claims." ${ }^{10}$ Since 1982, the Charter assisted with several queer-

\footnotetext{
10 David Rayside. Queer Inclusions, Continental Divisions: Public Recognition of Sexual Diversity in Canada and the United States (Toronto: University of Toronto Press, 2008), 92-93.
} 
related legal causes, including Egan and Nesbit v. Canada (1995), Vriend v. Alberta (1998), M.

v. H. (1999), and Little Sisters Book and Art Emporium v Canada (2000), before becoming a catalyst for the institutionalization of same-sex marriage in Canada. The outcomes of Hendricks v. Quebec (2002), Barbeau v. British Columbia (2003), and the aforementioned Halpern v.

Canada (2003) held that the exclusion of same-sex couples from the definition of marriage was a breach of Charter rights, and led to the drafting of the Civil Marriage Act in 2003, which became law on July $20^{\text {th }}, 2005$.

Second, these cases are indicative of activists' attempts to harness the visibility that media attention could afford them to raise awareness and potentially effect societal change. Certainly, the legalization of same-sex marriage in Canada represented the culmination of decades of same-sex marriage advocacy as well as provincial and national judicial decisions made in an effort to address the unconstitutionality of then-current legal doctrines. National and regional newspapers and other mass media reported on each event, updating the Canadian public sphere on recent developments and opinions. According to Bill Kovach and Tom Rosenstiel, journalism's value to any culture lies in its provision of “...independent, reliable, accurate, and comprehensive information that citizens require in order to make sense of the world around them." 11 The quality of democracy in any culture is dependent on the public having access to information, internalizing it, and applying it to their acts of citizenship. ${ }^{12}$ Knowledge of current affairs is a major contributor to the formation of public opinion - "...the collective consensus about political and civic matters reached by groups within larger communities". ${ }^{13}$ The formation

\footnotetext{
${ }^{11}$ Bill Kovach and Tom Rosenstiel, The Elements of Journalism: What Newspeople Should Know and the Public Should Expect (New York: Three Rivers Press, 2014), 4.

${ }^{12}$ Kovach and Rosenstiel, 9.

${ }^{13}$ Maxwell McCombs et al, The News and Public Opinion: Media Effects on Civic Life (Cambridge: Polity Press, 2011), 2.
} 
and change of public opinion depends on communication - neither a public nor an opinion could exist without it. ${ }^{14}$ News not only contributes to a citizen's political knowledge, but wields the potential of influencing feelings towards political issues directly or indirectly; exposure to an issue or perspective may directly lead to a new level of awareness by an individual audience member, and reflection about the ideas raised by the news item may indirectly result in in-person deliberation. $^{15}$

In light of this, as this dissertation demonstrates, since the Charter came into being, Canadian national print news - in continual relation to alternative news outlets — played a central role in the complex networks contributing to the emergence of same-sex marriage as law, as policy, and as cultural norm. Within a diversity of political, social, cultural, and religious voices, news reports from The Globe and Mail and the National Post framed the legalization of samesex marriage neutrally, within journalistic conventions for balance and objectivity; both publications presented traditional and equal rights frames in their opinion pieces to varying degrees, thereby exposing their readers to both sides of the debate. Through this, news opened a discursive space for many Canadians to consider supporting legal and legislated same-sex marriage. Crucially, however, in a post-Charter Canada, media have not consistently approached LGBTQ-related issues in this way - arguably the result of institutional homophobia. ${ }^{16}$ The news media have traditionally played a role in creating and regulating the boundaries of gender and sexual identities, usually privileging heterosexuality. ${ }^{17}$ As Peter Knegt notes, while mainstream Canadian media - more so since the twenty-first century than in early years of organizing - have

\footnotetext{
${ }^{14}$ McCombs et al., 3 .

${ }^{15}$ McCombs et al., 2-7.

${ }^{16}$ Gary Kinsman, The Regulation of Desire: Homo and Hetero Sexualities (Montréal: Black Rose Books, 1996), 34,

${ }^{17}$ Gayle S. Rubin, “Thinking Sex: Notes for a Radical Theory of the Politics of Sexuality,” in Culture, Society, and Sexuality: A Reader, (London: Routledge, 2007), 143-178.
} 
been friends of the queer community, newspapers and magazines "...have censored queer groups, been a platform for anti-gay organizations and have facilitated both heterosexist norms and homophobic hysteria through their editorial policies. ${ }^{18}$ Fortunately, Canadian queer media notably The Body Politic and its replacement, Xtra! - have not only served to combat the ideologies perpetrated by mainstream media, but have had a role in socially and politically organizing the community. ${ }^{19}$

My dissertation aims to determine how and why Canadian mainstream press oscillated between anti-queer and pro-LGBTQ approaches to news items in a post-Charter Canada. This involves addressing several questions: what roles have newspapers and mass media news in Canada played in the construction of a seemingly "liberal" public sphere? How did reporting by national print news affect public opinion between 1982 and 2005 toward the issue of same-sex marriage legalization? How did the alternative press respond? What is the role of heteronormativity in making the issue of marriage an "acceptable" LGBTQ demand? How might North American media practices explain why Canadian national print news covered issues in the manner that they did? What effect did media concentration in Canada have on how national print news outlets handled LGBTQ issues?

This dissertation completes a comprehensive study of Canadian national print news media frames, tracing the legalization of same-sex marriage in 2005 back to the year 1982, when equality rights advocacy gained momentum with the Charter of Rights and Freedoms. The proposed research contributes to the narrative of the development of marriage equality in Canada and the broader history of LGBTQ rights in the nation by exploring an absent chapter: how the Canadian news industry contributed to the framing of marriage equality within the specific

\footnotetext{
${ }^{18}$ Peter Knegt, About Canada: Homosexual Rights (Halifax: Fernwood Pub.,2011), 65

${ }^{19}$ Knegt, 70.
} 
context of the post-Charter Canadian public sphere. This is significant, for it reveals the role Canadian news media had in public debate and public policy formation concerning same-sex marriage. It is worthwhile to investigate how the media covered same-sex marriage and the relationship between this coverage and the social factors that helped shape it. Histories and analyses of news coverage of the legalization of same-sex marriage remain largely focused on the United States. While egalitarianism frames were implemented in US media, moralistic frames ${ }^{20}$ were prevalent in shaping the course of the debate (Brewer, $2002 \& 2003$; Tadlock, Gordon, and Popp, 2007; Liebler, Schwartz, and Harper, 2009; Li and Liu, 2010; Pan et al. 2010). Research concerning how this issue has been framed in Canada exists, focusing on litigants (Smith 2007), courts and legislatures (Matthews 2005), and Canadian newspapers (Bannerman 2012). Bannerman's study demonstrated that Canadian newspapers' sole frame in print news coverage between 2003 and 2004 was, in Bannerman's words, "tolerance". The politics of sexual diversity has been well researched for Canada (Hogg 2006; Kinsman 1996; Kinsman and Gentile 2010; Pettinicchio 2010; Rayside 2008; M. Smith 2008, 2012) and in Canadian historical contexts (Adams 1997; Chenier 2003, 2008; Maynard 1992; T. Warner 2002; Gentile, Kinsman, and Rankin, 2016), but the specific issue of marriage equality has not been studied extensively. This research can also be read in relation to critical analyses of controversies in the marriage debates in LGBTQ communities within North America (Griffin 2007; Stryker 2008; Muñoz 2009; Berlant 2011; Duggan 2011, 2012). Collectively, their work highlights the consequences of same-sex marriage - that is, rather than challenge heterosexist institutions and values, promotes inclusion in them and maintains their dominance, maintains the assumption that all queer people want to be part of the dominant, mainstream, heterosexual culture, and rewards

\footnotetext{
${ }^{20}$ Issues framed in terms of traditional moral values emphasize that legally granting same-sex marriages conflicts with long-standing social and religious institutions of marriage and family.
} 
those who do so. It also perpetuates a standard for what is an appropriate queer relationship, leaving the polyamorous and other non-normative relationship structures to the sidelines.

The dissertation makes use of two theoretical perspectives: the public sphere and framing. First, I will show how news reporting is symbiotically implicated in Canadian public perspectives by the notion of the public as a social space created through the circulation of discourse, perceived as rational, objective and authoritative. Second, I will reflect upon how the issue was ideologically positioned in print through framing analysis, which involves the selection and promotion of aspects of reality and experience to advance a specific viewpoint. According to Pippa Norris et al., “...understanding mass communications through the concept of framing has become increasingly common, whether in the fields of social psychology, public opinion, or media studies". ${ }^{21}$ Notably, Entman, Matthes, and Pellicano state that, “...communicators, most importantly reporters and news editors in mainstream national news media, normally engage in framing without intending to push any particular policy or political goal...,22 As will be demonstrated throughout this dissertation, I will recount the history of marriage equality in Canada in relation to predominant political and media theory of the time.

As part of my original contribution, I have conducted a quantitative content analysis on the issue as reported in national newspapers The Globe and Mail and the National Post. The reason for selecting these specific publications is twofold: not only did The Globe and Mail and the National Post specifically target a national market - thus having a high circulation across the country and being useful for the purposes of this study - but they were readily accessible via single-repository searchable archives. Content analysis is viable for "analyzing and mapping key

\footnotetext{
${ }^{21}$ Pippa Norris et al. "Introduction," in Framing Terrorism: The News Media, the Government and the Public, (New York: Routledge, 2003), 10.

${ }^{22}$ Robert M. Entman, et al. "Nature, Sources, and Effects of News Framing," in The Handbook of Journalism Studies, (New York: Routledge, 2009), 176.
} 
characteristics of large bodies of text, and lends itself well to the systematic charting of longterm changes and trends in media coverage. ${ }^{, 23}$ To accrue an accurate reading, a non-random, purposive sample was conducted on 1162 articles from The Globe and Mail and 971 articles from the National Post, regardless of what genre the text is and where it was placed in the newspaper. Articles were located via the ProQuest Historical Newspapers: Globe and Mail and Canadian Newsstream databases using the keywords 'same-sex marriage'. I chose this search term given that 'same-sex marriage' was terminology commonly used in both public discussions and academic study of marriage equality. ${ }^{24}$ Following the comprehensive content analysis of the census of national newspapers, I collected a non-random, purposive sample of two major Canadian LGBTQ print media (The Body Politic and Xtra!) for a timeline of 134 key stories between 1982 and 2005. The Body Politic articles were located via the Canadian Museum of Human Rights' digitized collection on Archive.org, while Xtra! articles were located at both The ArQuives in Toronto, Ontario (formerly the Canadian Lesbian and Gay Archives) and on Xtra's online repository (Dailyxtra.com).

News articles were chosen as the unit of analysis for they are easily accessible content that distributed frames of interest to the proposed study during the appropriate time period. In addition, according to C. Edwin Baker, newspapers perform various roles within a democracy, from alerting partisan groups when their interests are at stake, to helping to balance conflicting

\footnotetext{
${ }^{23}$ Anders Hansen and David Machin, Media and Communication Research Methods (London, UK: Palgrave Macmillan, 2013), 123.

${ }^{24}$ During the time period under investigation, the Canadian Press had scant press policies about gays and lesbians. Furthermore, there was no mention as to whether 'same-sex marriage', 'gay marriage' or 'marriage equality' were appropriate terminology to describe lesbian and gay weddings. Speaking to her experience as a former editor of The Canadian Press Stylebook in the 2000s, Patti Tasko revealed that the lack of specific style guidance offered flexibility for reporters to be able to make editorial decisions appropriate to the story on the ground. However, in response to developments in marriage equality in Canada, Tasko added information about terms for gay and lesbian partners (i.e. 'husband' and 'wife') in the $14^{\text {th }}$ edition, published in 2006. See: Tamara Baluja, "By the Stylebook: Gay Grammar and Describing Same-Sex Marriages," accessed January $23^{\text {rd }}, 2020$, https://j-source.ca/article/by-thestylebook-gay-grammar-and-describing-same-sex-marriages/.
} 
interests by having different voices be heard, and to creating a site for reflection. ${ }^{25}$ Given this, one can examine what roles Canadian newspapers played and investigate further why this was the case. What's more, Li and Liu state that "media coverage of issues of same-sex marriage sets the public agenda, as news coverage of issues of national importance often lead to further discussion on television and the Internet, and affects people's judgment on the issues and decisions in elections" ${ }^{26}$; as such, it is crucial to articulate, in this case, what might have been contributed and why this was the case.

The categories I have defined for analysis are relevant to the theoretical framework and my research objectives, and include: date of publication, newspaper, article type, and framing type (i.e. equal rights frame, traditional values frame, both, neutral). Furthermore, per Anders Hansen and David Machin, once categories "have been chosen and defined, they need to be set out in a codable form on a coding schedule"27 - essentially, a list of variables to be coded for each unit of analysis. A content coding schedule is presented in Appendix B. Furthermore, a coding analysis protocol used to articulate to coders what variables are to be coded and what their values are has been created; such a protocol provides definitions of variables and their values and allows for the results to be replicable. ${ }^{28}$ The coding analysis protocol for this research project can be found in Appendix B. The content analysis was conducted using Excel.

As a means to contextualize revelations from the content analysis and enhance the validity of my findings, I have conducted semi-structured interviews with journalists who wrote stories included in The Globe and Mail and the National Post, as well as Canadian gay activists

\footnotetext{
${ }^{25}$ C. Edwin Baker, Media, Markets, and Democracy (Cambridge, MA: Cambridge University Press), 129-192.

${ }^{26}$ Xigen Li and Xudong Liu, "Framing and Coverage of Same-Sex Marriage in US Newspapers," The Howard Journal of Communications 21, no. 1 (2010): 72-73.

${ }^{27}$ Hansen and Machin, 107.

${ }^{28}$ Hansen and Machin, 108.
} 
who were active during the late-twentieth and early twenty-first centuries. As such, the interviewees were selected from a non-random, purposive sample. Snowball sampling was used to help acquire additional participants to mitigate researcher bias. Questions were designed to determine the following: how media frames may have implicated understanding of the issue and level of support, and why and how certain frames were decided and implemented by journalists. During semi-structured interviews, prompts (i.e. news articles) were utilized to encourage discussion.

The dissertation is organized thematically into three chapters; this is done in order to best identify and explain the phenomena that had a part to play in shaping media representation of marriage equality and, consequentially, potentially affecting public opinion. Each chapter is organized to provide an overview of secondary histories before examining primary methodological documents. This is done because I am not making the presumption that the press documents or records history; rather, I am operating under the presumption that the newspaper is one of many factors that contributes to historical understanding. The second chapter serves as a foundational one, outlining the theoretical and historical background needed to make sense of the events under investigation. It begins by unpacking the theoretical concept of the public sphere, explaining how the circulation of ideas through print, and their subsequent consumption, internalization, and discussion enables individuals to ideologically position themselves as they wish; however, considering the role of framing in media asks us to consider the ways in which the public sphere is subject to influence by media framing. Indeed, taken together, both concepts allow for a deeper reflection of how Canadian national print news could affect citizens' opinion on marriage equality. Furthermore, in order to best determine if Canada abided by North American print media practices in reporting on marriage equality, it is imperative to assert what 
these practices are; this also involves considering the role of media consolidation on affecting the content produced. Finally, the chapter ends by establishing how, historically, LGBTQ people in Canada were treated by the national mainstream press; through this, historical trends in representation can be brought to the surface, thus not only evidencing a shift in representation, but allowing one to explain why such a shift has occurred.

The third chapter builds upon the foundation established in the previous chapter to explore not only what goes into producing journalism for the mainstream, but also what specifically the Canadian national print news published about marriage equality in a post-Charter nation. It begins by describing standards of journalism and the process of constructing news stories, including explaining the role of editors and journalists. It moves on to first assert how and when the marriage equality story appeared in the Canadian mainstream press before analyzing the results of the content analysis, thereby revealing the dominant frames exhibited by each publication. Accounts from journalists who wrote some of the published articles included in the sample contextualize these results; they offer insight into the construction of articles about same-sex marriage and their take on why representation shifted over time. Taken together, this chapter establishes the degree to which marriage equality was covered by national print publications in Canada, how this subject matter was treated and why it was treated as it was, and whether or not it is in alignment with known journalistic standards. This information enables one to analyze what content was actually disseminated to readers of Canadian national print newspapers, and how this might have affected their opinion on legalizing same-sex marriage.

If the third chapter focuses on the task of writing about marriage equality for the mainstream, then the fourth and final chapter investigates if mainstream coverage about the legalization of same-sex marriage in Canada accurately reflected the perspectives of the 
Canadian LGBTQ community. Doing so effectively requires that the history of the gay liberation movement in the nation, along with the rise of its gay press, be surveyed. Through this, I can determine where the issue of marriage equality fit into this history, and the circumstances surrounding its presence; this enables me to untangle the two diverging perspectives on marriage equality that emerged during this time - assimilationist and liberationist - and consider its effects on the movement at large. This is significant task for two reasons. First, given the dominance of assimilationist ideology in the gay activism of the late twentieth and early twentyfirst centuries, one can theorize the role heteronormativity had in making marriage equality a more palatable LGBTQ issue for the Canadian mainstream. Second, by considering the existence of this ideological split within the Canadian queer community, one can look to the community's own press to see the extent to which it made the differing perspectives visible; I can then look to the results of the previous chapter to consider whether or not this issue was taken up at all. On that note, the insights from the interviews with Canadian gay activists shed some additional light on how the voices of the community were reflected within the mainstream press; they offer their perspectives on why the framing was taken up in the way that it was and meditate upon their involvement in the production of mainstream stories on marriage equality.

The value of this research is multifaceted. On one level, it reminds us to be mindful of the influence that the news media has on one's ability to participate authentically in our civic duties. As a resource for information about current events and a distributor of opinion, the media informs the public on matters deemed important; the public uses this information to shape their own political beliefs, which may come to dictate their political actions. The means with which this information is packaged may influence how the public internalizes this information, thus having a role in manipulating perception and outcomes of political and social issues. So long as 
there is a news media, this remains a concern; indeed, in the era of social media, this matter is exacerbated, with fake news appearing on the screens of online denizens and being created and circulated at speeds difficult to stop. That said, this dissertation advances that one means with which we can better understand how social, cultural, and political change occurred is to evaluate how an issue was represented in news media, and to then assess the subsequent impact this might have had on public support for an issue and ultimately, the fate of societal progress.

In addition, the content of this dissertation contributes to the narrative of the development of marriage equality in Canada and the broader history of LGBTQ rights in the nation by exploring an absent chapter: how the Canadian news industry contributed to the framing of marriage equality within the specific context of the post-Charter Canadian public sphere. This is significant, for it is revealing of the role Canadian news media had in public debate and public policy formation concerning same-sex marriage; indeed, it is worthwhile to investigate how the media covered same-sex marriage and the relationship between this coverage and the social factors that helped shape the it.

This work also prompts reflection on the conditions that may allow for support of marriage equality to flourish in other parts of the world (note that, at the time of writing, samesex marriage is legalized in 30 countries). There is a unique opportunity here to compare the results from this dissertation to progress made in other parts of the world. It also encourages one to think carefully about the circumstances that dictate which social issues are viewed as worthwhile to inform an audience of, and what implication this has on fostering public opinion. With regard to the LGBTQ community, as this work demonstrates, the appeal to heteronormativity that the fight for marriage equality had is argued as having a large role in influencing its newsworthiness for the mainstream; how might the maintenance of the status quo 
affect the treatment of other issues facing the LGBTQ community in Canada, such as the blood ban for men who have had sex with men, HIV criminalization, and the deportation of LGBTQ refugees $?^{29}$

${ }^{29}$ Erica Lenti et al., “All the ways Canada is still screwing over LGBTQ2 people,” Xtra, June 28, 2019, https://www.dailyxtra.com/all-the-ways-canada-is-still-screwing-over-lgbtq2-people-158779. 


\section{Chapter 2: Reading the Public Sphere}

\section{Intro: Jim Egan}

When Toronto-based businessman Jim Egan first took to his old Underwood typewriter in 1949 to compose letters directed at North American mainstream publications, he aimed to critique their representations of homosexuality; Egan was reacting to the derogatory tropes that pervaded such media coverage, which were reflective of the moral panic that drove post-Second World War ideology. ${ }^{30}$ Egan, an openly gay Canadian, grew increasingly frustrated with the outrageousness of the content; from explorations of homosexuality as a curable biological abnormality to repeated discussion of the perceived association the figure of the homosexual and that of the sexual predator ${ }^{31}$, he observed that the mainstream press was apt to reinforce current societal ideologies. ${ }^{32}$ While Egan recognized that these representations abided by societal norms, he was resentful that they were always one-sided and lurid, and never attempted to offer an alternative perspective ${ }^{33}$; as Egan explains: "There were never any articles published from the gay point of view, which in my mind equaled a conspiracy of silence on the true nature of homosexuality. ${ }^{34}$ In an attempt to remedy this, Egan began to write letters of complaint to the editors of mainstream publications between 1949 and 1951; despite his best efforts to "...let them know that there was at least one person out there who was not going to sit by and let them get away with what [he] considered to be gross inaccuracies and libels, ${ }^{, 35}$ they remained

\footnotetext{
${ }^{30}$ Kathryn Campbell, “'Deviance, Inversion and Unnatural Love:' Lesbians in Canadian Media, 1950-1970,” Atlantis 23, no. 1 (1998): 129.

${ }^{31}$ Egan highlights the following two mainstream articles, published soon after the release of Kinsey's work, as exemplifying this trend: Allen Churchill, "What is a Homosexual?," Argosy, August 1949, 28-29, 97 and Ralph H. Major Junior, "New Moral Menace to Our Youth," Coronet, September 1950, 101-108.

32 Jim Egan, Challenging the Conspiracy of Silence: My Life as a Canadian Gay Activist Edited by Donald W. McLeod (Toronto: Canadian Lesbian and Gay Archives, 1998), 43-44.

${ }^{33}$ Egan, Challenging the Conspiracy of Silence: My Life as a Canadian Gay Activist, 44.

${ }^{34}$ Egan, Challenging the Conspiracy of Silence: My Life as a Canadian Gay Activist, 43.

${ }^{35}$ Egan, Challenging the Conspiracy of Silence: My Life as a Canadian Gay Activist, 44.
} 
unpublished, thus prohibiting Egan's voice from entering the larger public conversation about sexuality he had aimed to take part in.

It was in 1950 that Egan directed his attention toward Canadian tabloids, such as Flash, Hush, Justice Weekly, True News Times, and Police Patrol, whose commentary was more abusive and lewd than that of the mainstream press; realizing there were no known attempts to respond to these articles, Egan took it upon himself to make a point of how unjust and inaccurate these pieces were by writing letters to the editors. ${ }^{36}$ With Flash publishing Egan's response to their reporters’ exposé on Toronto’s ‘dangerous’ steam baths in May 1950, Egan threw himself into his letter writing. ${ }^{37}$ Egan was not limited to letters of complaint; his collection of writings grew to include three series on the subject of homosexuality, first for True News Times (1951) and later two series for Justice Weekly (1953-54). These series - which were pitched by Eganafforded him the opportunity to examine in sufficient depth the actualities of homosexual life with the aim of bringing about a better understanding of the subject to the general public; topics included: the history of homosexuality, the nascent U.S. homophile movement, the Kinsey Report, gay bars, McCarthyism, the media, medical and psychiatric theories about the causes of and cures for homosexuality, and the Criminal Code. Egan's perspectives were informed by thorough research, ${ }^{38}$ which provided the factuality needed to convince individuals of his claims. Crucially, the editors publishing Egan's work did not share his goals; Egan believed that editors included his writings as a means to stir up controversy - not because they were sympathetic towards gay people or their rights. ${ }^{39}$ By the time he decided to stop his writing campaign and

\footnotetext{
${ }^{36}$ Jim Loves Jack: The James Egan Story. Produced by David Adkin Productions, in association with Vision TV and the Knowledge Network. 53 minutes. 1995. DVD.

${ }^{37}$ Egan, Challenging the Conspiracy of Silence: My Life as a Canadian Gay Activist, 45.

${ }^{38}$ Egan, Challenging the Conspiracy of Silence: My Life as a Canadian Gay Activist, 51.

${ }^{39}$ Egan, Challenging the Conspiracy of Silence: My Life as a Canadian Gay Activist, 45.
} 
move on to other endeavors in 1964, Egan had published a total of eighty-nine pieces - thirty of which appeared in mainstream publications, and fifty-nine in tabloids.

For nearly two decades, Egan took advantage of the limited dialogical nature of tabloid journalism ${ }^{40}$ to challenge the content editors allowed to appear in the tabloid's pages, and, in doing so, spoke against prevailing societal ideologies; all this was done in an effort to challenge readers' thinking. Egan was aware of the power that publicizing his words through print could have, as they could create awareness amongst readers about the realities of being gay; through this education, readers might reconsider their stance on homosexuality and contribute to societal change through their subsequent beliefs and behaviours. By expressing his opinion through print, potentially instigating discussion of a societal issue, and hopefully shifting public opinion to be more understanding of the realities of gay life, Egan's efforts embodies both the capacity for print media to affect publicness and to bring into reality a social space with which to deliberate societal concerns and arrive at consensus (that is, a public sphere).

\section{Media and Publicness}

As reference to relevant literature in this section will demonstrate, communication media can encourage organization, information exchange, meaning production, and deliberation; individuals can utilize these processes to acknowledge and address societal causes. For the purposes of this dissertation, this theoretical framework may be applied to the investigation of the advancement of past societies, showing how a society's use of communication media may have informed subsequent societal transformations. We may begin with the work of James Carey, who, in the 1980s, argued that contemporary studies of communication were largely concerned with the capacity for information to be transformed - a 'transmission view of

\footnotetext{
${ }^{40}$ In other words, as a member of the audience, Egan was able to speak to the editors and other readers through the submission of letters, with the opportunity for them to be publicized.
} 
communication' - that saw communication simply as a process of simply transmitting and distributing messages. ${ }^{41}$ For Carey, the impact of communications is not limited to the mere transmission of information - a ritual view of communications should be considered. A ritual view involves viewing communications as a symbolic process, one in which "reality is produced, maintained, repaired, and transformed" ${ }^{\mathrm{N}}$; the creation, awareness, and use of symbolic forms are all elements inherent to communication, and conjure known reality. ${ }^{43}$ According to Carey, individuals have a large role in creating, sustaining, and altering this reality; the world, in his view, is produced by symbolic works created by people. ${ }^{44}$ This reality is not only created by people, but must be maintained by them; reality must be continually repaired in order to adapt to new challenges to current representations. ${ }^{45}$ When adaptation is no longer feasible, an existing representation of reality can be cast away, allowing for a new reality to come into being. ${ }^{46}$ Our creation, expression, and conveyance of information and beliefs towards the world around us is performed through symbols. ${ }^{47}$ Given this, a ritual view of communications reveals that reality is a social construct developed, produced, and maintained by people; as communication media disseminates specific ideologies, they may be consumed, internalized, upheld or adapted by audiences; as a result, they become bound to particular communities and shared experiences. Notably, reality constructed through media is not static, and can alter to reflect societal shifts that may take place. Ultimately, the ritual view of communication sees communication as an act that allows for and supports societal transformation.

\footnotetext{
${ }^{41}$ James Carey, Communication as Culture: Essays on Media and Society (Boston: Unwin Hyman, 1989), 15.

${ }^{42}$ Carey, 23.

${ }^{43}$ Carey, 25.

${ }^{44}$ Carey, 30.

${ }^{45}$ Ibid.

${ }^{46}$ Ibid.

${ }^{47}$ Ibid
} 
Carey's ritual view of communication stresses the role of communication in the creation of reality - in constructing a symbolic reality we share, uphold, and even adapt societal beliefs. This sets the stage for us to consider how publicness might emerge out of this reality-building. John B. Thompson speaks to what he calls 'the transformation of visibility' that has occurred as a result of communication media. Thompson identifies print as the instigator of the reconstitution of public and private life ${ }^{48}$; indeed, Thompson argues that publicness is mediated through communication processes. As Thompson explains, the development of the media has established new forms of publicness which operate differently than the traditional publicness of co-presence; media extends our availability, meaning that the "publicness of individuals, actions or events is no longer linked to the sharing of a common locale. ${ }^{, 49}$ With this in mind, the media have encouraged the emergence of new forms of 'mediated publicness', a phenomenon that Thompson sees as playing a significant role in our modern world. ${ }^{50}$ For Thompson, co-presence remains significant - public meetings, mass demonstrations, and political debates are key to advancing societal causes; however, pervasive mass media is the cause for new forms of publicness that are extending, transforming, and displacing that of the traditional form of publicness. ${ }^{51}$ In describing this renewed sense of publicness, Thompson advances the following: the transcendence by print of a shared locale with which to experience a public act meant the printing of events could acquire publicness; a reading public not localized in space and time was defined by the notion that members of it participated in the same publicness; to make something public was no longer limited to in-person conversations, and grew to be dependent on the

\footnotetext{
${ }^{48}$ John B. Thompson, The Media and Modernity: A Social Theory of the Media (Stanford, California: Stanford University Press, 1995), 125.

${ }^{49}$ Thompson, 125-126.

${ }^{50}$ Ibid.

${ }^{51}$ Ibid.
} 
creation and distribution of text, and; individuals could learn about the world around them through the act of reading, which removed individuals from the actual event but still enabled them to learn about it. ${ }^{52}$ Given this in relation to Carey's ideas, the reality that is constructed through communication media - a reality that includes the development of social bonding - is made possible through the appearance of a new form of publicness.

Benedict Anderson also speaks to the potential of print to promote social cohesiveness. In an effort to "offer some tentative suggestions for a more satisfactory interpretation of the 'anomaly' of nationalism," ${ }^{, 53}$ Anderson suggests that a nation:

is an imagined political community... it is imagined because the members of even the smallest nation will never know most of their fellow members, or even hear them, yet in the minds of each lives the image of their communion...In fact, all communities larger than primordial villages of face-to-face contact (and perhaps even these) are imagined. Communities are to be distinguished, not by their falsity/genuineness, but by the style in which they are imagined. ${ }^{54}$

To exemplify this notion, Anderson notes that, in eighteenth-century Europe, imagined communities came into existence through the newspaper and the novel, as these media were thought to provoke within readers a sense of national belonging. ${ }^{55}$ Anderson argues that the act of reading a national newspaper inspires individuals to be conscious of their belonging to a national community, the capacity for others to belong to that same national community, and the existence of alternative nations within the same spatiotemporal realm. ${ }^{56}$ Similarly, nationalist content conjures feelings of an imagined community as individuals are thought to grasp references made to national customs and ideologies inherent in a particular text, thereby feeling

\footnotetext{
52 Thompson, 126-127.

${ }^{53}$ Benedict Anderson, Imagined Communities: Reflections on the Origin and Spread of Nationalism (New York: Verso, 2006), 4.

54 Anderson, 6.

${ }^{55}$ Anderson, 25-35.

${ }^{56}$ Anderson, 26.
} 
bonded to the text, as well as to their fellow citizens. ${ }^{57}$ Print encourages readers to imagine themselves as one of a collective, thereby serving as a unifying instrument, and can thus be seen as a means with which social consciousness can be created.

\section{Public Sphere Theory}

This relationship between media and publicness creates an environment that is hospitable to citizens' democratic participation - the phenomenon of the public sphere is indicative of this. The public sphere is a concept that helps to make sense of how modern liberal democratic societies function, and the role of citizens in this; it does so by describing the means by which citizens arrive at consensus on societal concerns. ${ }^{58}$ As Alan McKee writes, "This makes it useful for understanding how political communication works in [democratic countries]; for thinking about how wider social and cultural issues are addressed; and for trying to make sense of how agreement about what it is acceptable in a culture is reached." ${ }^{\text {"5 }}$ Jürgen Habermas, the German philosopher and sociologist who aroused renewed interest in matters of the public sphere when his work on the subject was translated into English in the 1980s, defines the public sphere as: "a domain of our social life where such a thing as public opinion can be formed [where] citizens...deal with matters of general interest without being subject to coercion...[to] express and publicize their views. ${ }^{, 60}$ Notably, the public sphere is a metaphorical term used to describe the virtual social space where people interact; ${ }^{61}$ that said, it is within this space that

\footnotetext{
${ }^{57}$ Anderson 7, 30-32.

${ }_{58}^{58}$ Alan McKee, The Public Sphere: An Introduction (New York, NY: Cambridge University Press, 2005), 6.

${ }^{59}$ Ibid.

${ }^{60}$ Jürgen Habermas, 'The Public Sphere', in Robert E. Goodin and Phillip Petit (eds) Contemporary Political Philosophy: An Anthology (Oxford: Blackwell Publishers 1997): 105.

${ }^{61}$ John Hartley, The Politics of Pictures: The Creation of the Public in the Age of Popular Media (New York: Routledge, 1992): 1.
} 
“...information, ideas and debate can circulate in society, and where political opinion can be formed. ${ }^{.62}$ As Mckee explains:

It's where each of us finds out what's happening in our community, and what social, cultural, and political issues are facing us. It's where we engage with these issues and add our voices to discussions about them, playing out part in the process of a society reaching a consensus or compromise about what we think about issues, and what should be done about them. ${ }^{63}$

In other words, the public sphere is "the central arena for societal communication"64; in largescale societies, mass media is the foundation that supports and sustains communication in the public sphere. ${ }^{65}$ As Habermas states: "when the public is large this kind of communication requires certain means of dissemination and influence; today, newspapers and periodicals, radio and television are the media of the public sphere."

That said, the public sphere is a notion that finds itself entrenched in the history of Western political philosophy; it begins with the emergence of modernity in the seventeenth century - "a historical period that began in Western Europe with a series of profound socialstructural and intellectual transformations in the seventeenth century and achieved its maturity as a cultural project with the growth of the Enlightenment and later with the development of industrial society. Modernity is associated with order, certainty, harmony, pure art, absolute truth. ${ }^{, 67}$ Enlightenment values were established as a means to organize society, in theory ensuring that all citizens were equal, treated fairly, free, and had comfort. ${ }^{68}$ Societies at the time were shifting from a feudal and hierarchical structure, and in order to maintain equality, social

\footnotetext{
${ }^{62}$ Peter Dahlgren, Television and the Public Sphere (Thousand Oaks, Calif.: Sage Publications, 1995): ix.

${ }^{63}$ McKee, 5 .

${ }^{64}$ Hartmut Wessler and Rainer Freudenthaler, "Public Sphere," last modified January 11, 2018, https://www.oxfordbibliographies.com/view/document/obo-9780199756841/obo-97801997568410030.xml\#firstMatch.

${ }^{65} \mathrm{Ibid}$.

${ }^{66}$ Habermas, 1997, 105.

${ }^{67}$ Madan Sarup, Identity, Culture and the Postmodern World (Edinburgh: Edinburgh University Press, 1996): 5.

${ }^{68}$ Mckee, 7 .
} 
organizations had to be restructured; with a sense of equality embraced, citizens were thought to be able to have input into political decisions made - something impossible in the existing political structure of absolutist monarchy. ${ }^{69}$ Given this, ways in which to exchange information and ideas had to be established by citizens in order to reach consensus about what they wanted done and to communicate this information to those members of the society in power; the formation of public venues and publications were the byproduct of this. ${ }^{70}$ Consequently, the will of the people was formed and expressed in the emerging political public sphere; those governing could no longer appeal to divine right to justify their legitimacy, but were meant to attend to the concerns of their citizens. $^{71}$

The idea of the public sphere has developed over time since its origins in the eighteenth century; several thinkers have provided commentary on the public sphere's role in democratic societies; the concept has - and continues to be - highly contested, with there being a lack of agreement in terms of how the public sphere may be workable. For instance, amidst the emergence of the Enlightenment era, Immanuel Kant stressed the capacity to publicly reason allowed for both personal autonomy as well as political legitimacy ${ }^{72}$; in contrast, G.W.F. Hegel expressed concern over unorganized public opinion and citizens' irrationality ${ }^{73}$, while John Stuart Mill feared the mass majority would hold sway without debate ${ }^{74}$. As another example, the shift to mass society in the twentieth century saw similar optimism and pessimism regarding

\footnotetext{
${ }^{69}$ Jürgen Habermas, The Structural Transformation of the Public Sphere: An Inquiry into a Category of Bourgeois Society, trans. Thomas Burger (Cambridge, Mass.: MIT Press, 1989), 26.

${ }^{70}$ McKee, 7-8.

${ }^{71}$ Iostein Gripsrud et al., "Editors Introduction," in The Idea of the Public Sphere: A Reader, eds. Iostein Gripsrud et al. (Lanham, Maryland: Lexington Books, 2010), xiii.

${ }^{72}$ Immanuel Kant, "An answer to the question: What is enlightenment?" in Practical Philosophy, trans. and ed. Mary J. Gregor (New York: Cambridge University Press, 1996), p. 11-22.

${ }^{73}$ Georg Wilhelm Friedrich Hegel, Philosophy of Right, trans. S.W. Dyde (Amherst, New York: Prometheus Books, 1996), p. 204-208.

74 John Stuart Mill, "Of the Liberty of Thought and Discussion," On Liberty, ed. Edward Alexander (Peterborough, Ont.: Broadview Press, 1999), 58-100.
} 
democracy and public opinion, best represented by the debates between Walter Lippmann and John Dewey. Lippmann was concerned that the complexity of contemporary society was too much for citizens to comprehend, and as a result, they were not capable of making useful contributions to democracy; as a result, experts should be in charge of evaluating information and offering it to decision-makers. ${ }^{75}$ In contrast, Dewey staunchly advocated for the public deliberation as inherent to democracy, and advanced the public sphere as a realm in which ordinary people learned to become competent citizens by collectively sharing knowledge and ideas and exploring all sides of an argument. ${ }^{76}$ Contemporary research on the public sphere sprung from developments in public sphere research emerging in the latter part of the $20^{\text {th }}$ century, beginning with Hannah Arendt's The Human Condition. Here, Arendt explores the operation of the public and private spheres in Ancient Greece, emphasizing that the former was a realm of politics, actions, and excellence - a space to be seen and heard by other men through public activities, such as democratic assemblies, courts, theatre, and battlefields - while the latter was a space of deprivation from public attention. ${ }^{77}$ Habermas' The Structural Transformation of the Public Sphere - originally published in German in 1962, but translated into English over thirty decades later - became a major catalyst for the resurgence of debates over the public sphere. ${ }^{78}$ It is beyond the scope of this work to delve deeper into the examination of the full body

\footnotetext{
${ }^{75}$ Walter Lippmann, Public Opinion (Toronto: Free Press Paperbacks, 1997), 399.

${ }^{76}$ John Dewey, The Public and its Problems (Athens, Ohio: Swallow Press/Ohio University Press, 1991), $192-217$.

${ }^{77}$ Hannah Arendt, The Human Condition, $2^{\text {nd }}$ ed. (Chicago: University of Chicago Press, 1998), 28-58.

${ }^{78}$ See, for instance: James Curran "Rethinking the media as a public sphere", in Communication and Citizenship: Journalism and the Public Sphere in the New Media Age, Peter Dahlgren and Colin Sparks (eds) (New York: Routledge, 1991): 27-57; Calhoun, Craig J., ed. Habermas and the Public sphere (Cambridge, Mass.: MIT Press, 1992); Sonia Livingstone and Peter Lunt, "The mass media, democracy and the public sphere," in Talk on Television: Audience Participation and Public Debate (London: Routledge, 1994): 9-35; Peter Dahlgren, Television and the Public Sphere (Thousand Oaks, Calif.: Sage Publications, 1995); Mike Hill and Warren Montag, eds., Masses, Classes, and the Public Sphere (New York, N.Y.: Verso, 2000); Nick Crossley and John Michael Roberts, eds., After Habermas: New Perspectives on the Public Sphere (Malden, MA: Blackwell Publishing, 2004. Alan MacKee, The Public Sphere: An Introduction (New York, NY: Cambridge University Press, 2005); Sonia Livingstone, "On the Relations Between Audiences and Publics," in Audiences and Publics: When Cultural Engagement Matters for the Public Sphere, Sonia Livingstone ed. (Portland, Or.: Intellect, 2005): 17-42.
} 
of literature; as such, to further introduce the public sphere and address how it serves as a framework for the current research, I will explore three specific works. These theories of the public sphere best represent the context of the production of journalism between 1982 and 2005, and the context in which journalists and gay activists were working.

Habermas's The Structural Transformation of the Public Sphere - originally published in German in 1962, but translated into English over thirty decades later - became a major catalyst for the resurgence of debates over the public sphere. Through a historical exploration of the origins of a bourgeois public sphere in seventeenth and eighteenth-century European social institutions and political philosophy, Habermas develops a normative model of the public sphere ${ }^{79}$; per his writing, the public sphere, as it functioned at this time, depended on this use of reason in rational-critical debate as a means to check domination by the state while also forwarding its interests; such debate occurred in the circles of the bourgeois reading public, who were reacting to contemporary literature, and in salons and coffee houses, and took place independent of public authority. From the literary public sphere sprang the political public sphere at the turn of the eighteenth century in Britain; Habermas writes, "forces endeavoring to influence the decisions of state authority appealed to the critical public in order to legitimate demands before this new forum." ${ }^{90}$ This was abetted by elimination of censorship, which "marked a new stage in the development of the public sphere. It made the influx of rationalcritical arguments into the press possible and allowed the latter to evolve into an instrument with whose aid political decisions could be brought before the new forum of the public." ${ }^{81}$ The public sphere was inclusive only property owners and head of households. The public sphere becomes

\footnotetext{
${ }^{79}$ Richard Butsch, "Introduction: How Are Media Public Spheres?" in Media and Public Spheres, ed. Richard Butsch (New York, NY: Palgrave MacMillan, 2007), 2.

${ }^{80}$ Habermas, The Structural Transformation of the Public Sphere, 57.

${ }^{81}$ Habermas, The Structural Transformation of the Public Sphere, 58.
} 
re-feudalized, according to Habermas, as the rise of advertising, marking, and public relations in the twentieth century were purported to manipulate and manufacture consensus and minimize critical thinking; Habermas claims we have returned to a time where those in charge - the state, political parties - venture before the public seeking their support, rather than be the subject of critical debate. However, while one may garner from Habermas' work the notion that publicness may be ushered into being through print, Habermas's model is heavily discriminatory, excluding voices alternative to the bourgeois from participation in the public realm; it is the bourgeois who congregate as a public, and through the publication and internalization of material created for their interests, propagate the public sphere.

Daniel C. Brouwer observes that, in an attempt to remedy this, the theoretical concept of the counterpublic has been deployed by scholars to advance the following notions: that individuals participate in multiple publics; inherent in publics is the potential to not only address their own members, but other publics as well, with the opportunity to exert pressure on other publics, regardless of their status (i.e. dominant or subordinate); and that resource disparities among social actors exist. ${ }^{82}$ An early attempt to challenge Habermas's singular bourgeois public sphere came in the form of Oskar Negt and Alexander Kluge's Public Sphere and Experience: Toward an Analysis of the Bourgeois and Proletarian Public Sphere (1972); this text saw the first mention of counterpublic (Gegenöffenlichkeit in German) in print, a conceptual model meant to question the bracketing inherent in Habermas' conceptual framework. ${ }^{83}$ This conceptual tool was used to "posit the proletarian public sphere as a counterpublic." 84 According

\footnotetext{
${ }^{82}$ Daniel C. Brouwer, "Communication as Counterpublic," in Communication As...Perspectives on Theory, eds. Gregory J. Shepherd, Jeffrey St. John, and Ted Striphas (Thousand Oaks, Calif.: Sage Publications, 2006), 198-201.

${ }^{83}$ Miriam Hansen, introduction to Public Sphere and Experience: Toward an Analysis of the Bourgeois and Proletarian Public Sphere, Oskar Negt and Alexander Kluge (Minneapolis: University of Minnesota Press, 1993, xxvii.

${ }^{84}$ Brouwer, 196.
} 
to Christian Fuchs, the development of the proletarian counterpublic was served in part by the creation and presence of left-wing media: "Negt and Kluge are interested in left-wing media: the control of the intellectual means of production and the actual production of counter-ideas by the political left." ${ }^{85}$ Negt and Kluge's counterpublic placed emphasis on the following: "human experience; its dependence on perceptions of oppositionality; and its relational, provisional, and, thus, shifting constitution." ${ }^{, 86}$ The duo argue that Habermas's positive presentation of the classical bourgeois public sphere reflects the bourgeoisie's belief that the borders between the public and the private, between economy/work and the sphere of intimacy, between politics and art must be respected, divisions that the labour movement had also reproduced in its organizational structures and work. Against this, they proposed a "counter public sphere," which they called the 'proletarian public sphere' based on communication and learning in extreme situations of social and political struggle where they argue, the real connections between work, family life, and leisure activities are exposed and reflected upon.

Nancy Fraser demonstrates how certain groups were excluded from the public sphere on the basis of gender, property, and race, and argues that Habermas failed to examine other, competing public spheres. Fraser's distinction between strong and weak publics has been very influential. In the latter, deliberative practice consists of opinion making only, while the discourse in the former encompasses opinion formation and decision making. Fraser's intervention also marks the opening up of the theory of the public sphere to the challenges on an era of diversity, globalization, and digitization. Fraser begins this work by asserting the importance of critical theory to the assessment of democracy in late capitalist societies; for Fraser, Habermas's conceptualization of the bourgeois public sphere wields tremendous potential

\footnotetext{
${ }^{85}$ Christian Fuchs, Foundations of Critical Media and Information Studies (New York: Routledge, 2011), 305.

${ }^{86}$ Brouwer, 196.
} 
to positively inform critical theory, as well as "to democratic political practice." 87 Indeed, Fraser assumes that "no attempt to understand the limits of actually existing late capitalist democracy can succeed without in some way or another making use of it ${ }^{\prime 88}$ Despite this, Fraser perceives the bourgeois public sphere model Habermas imagines as troublesome; Habermas does not devise a post-bourgeois public sphere, nor does he take issue with the problematic suppositions inherent in his theory. Given this, Fraser asserts her main argument - that Habermas's work does not develop a notion of the public sphere that can effectively inform critical theory.

In advancing this argument, Fraser points to the revisionist histories produced by Joan Landes, Mary Ryan, and Geoff Eley as producing evidence that speak to the contrary. Cumulatively, these scholars identify those gender and class exclusions perpetrated by the rise of the 'official' bourgeois public sphere in order to maintain its dominance, as well as the existence of counterpublics that challenged the public sphere and engaged in varying forms of political activity and public address; Habermas does not consider these counterpublics in his treatment of the public sphere. This revisionist history prompts Fraser to question the validity of Habermas's notion of the public sphere, leading her to claim the idea of the bourgeois public sphere was "a masculinist ideological notion that functioned to legitimate an emergent form of class rule" ${ }^{\natural 9}$. For Fraser, this revisionist history encourages the critical analysis and re-evaluation of Habermas's conception of the public sphere; such a history illuminates four concerning assumptions implicit in Habermas's bourgeois public sphere, and through a critique of each, Fraser is able to postulate a post-bourgeois public sphere that can be appropriately deployed by critical theory.

\footnotetext{
${ }^{87}$ Nancy Fraser, "Rethinking the Public Sphere: A Contribution to the Critique of Actually Existing Democracy," in Habermas and the Public Sphere, ed. Craig Calhoun (Cambridge, Mass.: MIT Press, 1989), 57.

${ }^{88}$ Ibid.

${ }^{89}$ Fraser, 62.
} 
The first assumption made is that political democracy can be practiced through exclusionary measures; while the public sphere was to be a space in which differences were set aside, inequality was simply bracketed. Fraser counters that only with the elimination of social inequality can participatory parity be fostered. The second assumption insinuates that democracy is threatened by the existence and operation of multiple completing publics; as Fraser reveals, a single public sphere encourages an environment in which only selected voices and concerns are addressed. In contrast, subaltern counterpublics are vital arenas for the marginalized to mobilize, ascertain their identities, concerns, and opinions, and engage with the public sphere, thus fueling democratic participation. The third assumption puts forth that concerns related to private issues have no place for deliberation in the public sphere, which must only concern itself with publicoriented topics. This is concerning, as such issues are deemed personal and domestic are excluded from discussion, prompting for them to be de-legitimized and allowing for them to remain unaddressed. In response, Fraser illustrates the importance of having a public sphere that is receptive not only to the political, but subject matter that is intimate. Finally, the fourth assumption suggests that for a democratic public sphere to function, civil society and the state must remain separate. In practice, such an occurrence encourages weak publics that can merely deliberate and form opinion, not directly influence decision-making processes or policy creation; to allow otherwise, Habermas implies, would prompt for the public to become the state, thereby removing an entity that could uphold accountability. Fraser envisions a revision of the relationship between weak publics and strong publics (i.e. "publics whose discourse encompasses both opinion-formation and decision-making"90) in which both are inextricable from democratic processes.

\footnotetext{
${ }^{90}$ Fraser, 75.
} 
By the time Fraser has reached her conclusion, she has demonstrated that the bourgeois public sphere "is not adequate for the critique of the limits of actually existing democracy in late capitalist societies" ${ }^{\prime 1}$; in arguing against four assumptions of the bourgeois conception of the public sphere, Fraser theorizes "some corresponding elements of a new, post-bourgeois conception" ${ }^{92}$. Through this, Fraser advances an alteration of Habermas's public sphere theory that makes it more applicable to investigations of modern democracy.

Michael Warner's Publics and Counterpublics is valuable in that it challenges how the social sciences have come to understand publics and counterpublics - entities that engage with the public sphere. In his view, the study of publics and counterpublics conceive them as being existing, fixed, empirical entities ${ }^{93}$. In contrast, Warner proposes that we consider publics and counterpublics as animated, dynamic, and multifaceted $;{ }^{94}$ indeed, publics are not already fixed spaces, but are the result of processes, practices, and interactions. In this text, Warner provides a taxonomy of the different styles of reflexive behavior that characterizes publics; as Warner stresses, the behaviours that come to inform publics are generated by discursive practices ${ }^{95}$. Warner stresses that, in order for any public to come into formation, that public must: be selforganized; constitute a relation amongst strangers; involve public speech that is personal and impersonal; be fostered via attention; be a social space fostered through ongoing dissemination of content; act in accordance to the historical circumstances in which they emerge; and contributes to the construction of the world around us. To briefly expand on some of these points, a public is constituted as a space of discourse organized by discourse and is done so

\footnotetext{
${ }^{91}$ Fraser, 77.

${ }^{92}$ Ibid.

${ }^{93}$ Michael Warner, Publics and Counterpublics (New York: Zone Books, 2002), 15.

${ }^{94}$ Ibid.

${ }^{95}$ Warner, 67.
} 
independent of institutions ${ }^{96}$. As a relation among strangers, a public must use its discourse to address "...people who are identified primarily through their participation in the discourse and who therefore cannot be known in advance" $"$. Featuring address that is personal and impersonal, publics features speech that is addressed to targeted individuals and strangers, in the processing giving social relevance to private thought and life ${ }^{98}$. For a public to be a social space created by the reflexive circulation of discourse refers to the fact that a public must be "... understood to be an ongoing space of encounter for discourse" with publics being created through a succession of texts often in response to one another, not simply one text $\mathrm{t}^{99}$. Furthermore, circulation of content helps in world-building; as Warner notes: "writing to a public helps to make a world insofar as the object of address is brought into being partly by postulating and characterizing it" ${ }^{100}$ The punctuality of the circulation of a public's discourse is key to informing the pace at which this public functions. ${ }^{101}$ Indeed, Warner's work demonstrates that discourse is foundational to the constitution of publics, serving as the impetus for them to independently and reflexively define, revise, and articulate their goals to the both themselves masses on an ongoing basis, thus being able to engage with broader public spheres with clearly defined concerns, plans of action, and goals.

The notion of the public sphere enriches our understanding of the potential for individuals to have a direct hand in developing and articulating a public will and influencing political decision-making. Involvement in the public sphere is a potent means with which citizens may come to influence governmental action in the modern era through the production of

\footnotetext{
${ }^{96}$ Warner, 68.

${ }^{97}$ Warner, 74.

${ }^{98}$ Warner, 76.

${ }^{99}$ Warner, 90.

${ }^{100}$ Warner, 64.

${ }^{101}$ Warner, 95.
} 
public opinion; this public opinion is formed so long as a public has the opportunity to participate in rational discussion through media that encourage discourse, which has been facilitated through mediated forms of communication since the eighteenth century. This is due to the fact that access to tools of discourse enables individuals with the opportunity to mobilize and organize likeminded people, to define their concerns and develop an opinion, to engage in continuous dialogue that see these concerns shift overtime, and ultimately voice their opinion and converse with other publics about them in an attempt to instigate societal change. While the conceptualization of the bourgeois public sphere demonstrates severe exclusions to democratic participation, it is apparent that it is in fact possible for marginalized groups to find power in utilizing media to engage with authorities on issues of importance to them through engagement in their own counterpublics, thus leveling the democratic playing field and ensuring that a wealth of issues is being presented towards decision makers. Alan Mckee states that the public sphere is a useful concept "...for researchers who believe that ordinary citizens play a role in the creation and distribution of how society works"; ${ }^{102}$ that said, this work will show how news reporting is symbiotically implicated in Canadian public perspectives by the notion of the public as a social space created through the circulation of discourse, perceived as rational, objective and authoritative.

\section{Framing Theory}

In the large-scale societies that have developed since the turn of the twentieth century, mass media have become fundamental in the sustenance of communication in the public sphere. The previous section has highlighted the democratic potential inherent in the public sphere itself, as it allows citizens to play a role in the articulation of public will and influence governmental

\footnotetext{
${ }^{102}$ McKee, 10.
} 
action; that said, it is necessary to take a step back and reflect upon the creation of media content that has such a significant impact on opinion formation - the very opinion formation that might lead to acts of citizenship. How might the presentation of an issue through the media implicate perception about that very issue? What effect might this have on the authenticity of public opinion that is generated?

Framing is a concept that provides the theoretical tools to further contemplate the media's role in political life. Its origins can be traced to sociologist Erving Goffman, who, in the mid1970s, developed framing as an interpersonal theory to make sense of how individuals rely on expectations to make sense of their everyday social experiences; ${ }^{103}$ since then, framing has been taken up by media scholars who seek to investigate how issues are constructed, discourse is structured, and meanings are developed. ${ }^{104}$ Despite decades of framing research in the social sciences and humanities, there remains theoretical and empirical vagueness; as evidence of this, Robert M. Entman (1993), Dietram A. Scheufele (1999), and Dennis Chong and James N. Druckman (2007) have each offered their own attempts to provide cohesive models. Despite such variance in the application of framing concepts, according to Scheufele, the one element that draws them together is that framing has to be defined and operationalized on the basis of social constructivism. ${ }^{105}$ That said, it is not the purpose of this dissertation to resolve any theoretical ambiguities surrounding framing, nor to make an inventory of the research literature regarding it, but to instead identify the most frequently cited and useful definitions that can be

\footnotetext{
${ }^{103}$ See: Erving Goffman, Frame Analysis: An Essay on the Organization of Experience (Cambridge, Mass.: Harvard University Press, 1974).

${ }^{104}$ Stephen D. Reese, "Prologue - Framing Public Life: A Bridging Model for Media Research," in Framing Public Life: Perspectives on Media and Our Understanding of the Social World, Stephen D. Reese, Oscar H. Gandy, Jr., August E. Grant, eds. (Mahwah, N.J.: Lawrence Erlbaum Associates, 2001): 7-31.

${ }^{105}$ Dietram A. Scheufele, "Framing as a Theory of Media Effects," Journal of Communication 49, no. 1 (1999): 105
} 
utilized to understand this phenomenon and how it may be used to theorize opinion formation. ${ }^{106}$ In one of the most common citations, Entman explains: "To frame is to select some aspects of a perceived reality and make them more salient in a communicating text, in such a way as to promote a particular problem definition, causal interpretation, moral evaluation, and/or treatment recommendation." 107 Reese offers the following working definition that takes into account the framing tradition: "Frames are organizing principles that are socially shared and persistent over time, that work symbiocally to meaningfully structure the social world." ${ }^{\prime 108}$ The thread weaving the framing tradition together is the notion that communication organizes reality, provides meaning, and advances particular interpretations; Chong and Druckman's explanation of the premise of framing theory encapsulates this, while emphasizing the potential impact on opinion formation: "an issue can be viewed from a variety of perspectives and be construed as having implications for multiple values or considerations. Framing refers to the process by which people develop a particular conceptualization of an issue or reorient their thinking about an issue."109 Given the ambiguity of framing studies, it comes as no surprise that framing research has followed a bifurcated path, with either sociological and psychological conceptions of framing being adopted. According to Vincent Price, Lilach Nir, and Joseph N. Cappella, framing research with a sociological bent views frames as emerging from social and cooperative practices, while a

\footnotetext{
${ }^{106}$ See, for instance: David Morley, "Industrial conflict and the mass media," The Sociological Review 24, no. 2 (1976): 245-268; Todd Gitlin, The Whole World is Watching: Mass Media in the Making \& Unmaking of the New Left (Berkeley : University of California Press, 1980); William A. Gamson and Andre Modigliani, "Media Discourse and Public Opinion on Nuclear Power: A Constructionist Approach," American Journal of Sociology 95, no. 1 (1989): 1-37; Shanto Iyengar, Is Anyone Responsible?: How Television Frames Political Issues (Chicago: University of Chicago Press, 1991).

${ }^{107}$ Robert M. Entman, "Framing: Toward clarification of a fractured paradigm." Journal of Communication 43, no. 4 (1993): 52.

${ }^{108}$ Reese, 11 .

${ }^{109}$ Dennis Chong and James N. Druckman, "Framing Theory," Annual Review of Political. Science 10 (2007): 104.
} 
more psychological approach examines cognitive response to media messages. ${ }^{110}$ A sociological conception of framing is applied to the production of news discourse and conversations amongst focus-group participants, and is concerned with examining various media frames as they are applied to particular issues; ${ }^{111}$ a psychological conception of framing focuses on individual patterns of information processing and opinion formation, and is experimental, examining how individual cognitions and attitudes are affected by frames. ${ }^{112}$ Given that this research is concerned with how journalists working for Canadian national print news framed the issue of same-sex marriage and is thus concerned with the process involved in the construction of these frames, this work will adapt a sociological approach to framing.

As a form of research informed by social constructivism, a constructionist model is deployed in framing research; in such an approach, "media audiences are viewed as active in interpreting and discussing public events, but they rely on the mass media to provide common frames of reference that guide interpretation and discussion." ${ }^{\prime 13}$ This makes sense, especially when we consider that "frames evolve out of collective efforts to make sense of problems, and they help people 'locate, perceive, identify, and label' their experience." "114 Price et al. remind us that, "In the political world, multiple frames emerge naturally in the course of public debate.

\footnotetext{
${ }^{110}$ Vincent Price, Lilach Nir, and Joseph N. Cappella, "Framing Public Discussion of Gay Civil Unions," Public Opinion Quarterly 69, no. 2 (2005): 181.

${ }^{111}$ See, for instance: Gaye Tuchman, Making News: a Study in the Construction of Reality (New York: Free Press, 1978); Todd Gitlin, The Whole World is Watching: Mass Media in the Making \& Unmaking of the New Left (Berkeley : University of California Press, 1980; William A. Gamson and Andre Modigliani, "Media Discourse and Public Opinion on Nuclear Power: A Constructionist Approach,” American Journal of Sociology 95, no. 1 (1989): 137; Zhongdang Pan and Gerald M. Kosicki, "Framing Analysis: An Approach to News Discourse," Political Communication 10, no. 1 (1993): 55-75.

${ }^{112}$ See, for instance: Shanto Iyengar, "Television news and citizens' explanations of national affairs," American Political Science Review 81, no. 3 (1987): 815-831; Paul R. Brewer, "Framing, value words, and citizens' explanations of their issue opinions," Political Communication 19, no. 3 (2002): 303-316; Thomas E. Nelson, Rosalee A. Clawson, and Zoe M. Oxley, "Media framing of a civil liberties conflict and its effect on tolerance," American Political Science Review 91, no. 3 (1997): 567-583.

${ }^{113}$ Price et al., 180 .

${ }^{114}$ Goffman, 21.
} 
People on different sides of an issue understand it differently, focus on different aspects of the problem, and actively promote their perspective in arguing for favoured courses of action.”115 Amidst this, as advanced in the work of William A. Gamson, citizens make use of their experiences and interpersonal discussions, not just frames, to negotiate socially the meaning of political issues. Relating this to framing studies, William A. Gamson and Andre Modigliani put forth that, within a constructionist model of framing, "media discourse and public opinion are treated as two parallel systems of constructing meaning"; ${ }^{116}$ in other words, the cultural and the cognitive work alongside each other to inform public discourse. As the scholars go on to illustrate, public discourse over any issue encompasses the cultural (i.e. an array of interpretive packages of metaphors, catchphrases, visual images, and moral appeals presented by the media in its coverage) and the cognitive (i.e. meanings negotiated by citizens as they interact with the press and engage with their fellow citizens). ${ }^{117}$ Together, these make up the 'issue culture' surrounding matters of public debate, and the overall process is considered a 'symbolic contest' over competing interpretations. ${ }^{118}$ In the end, as Price et al. note: "Frames enjoy success or failure depending on resonances with popular thinking, active elite sponsorship, and media practices that might favour some frames over others. Frames develop in a dialectic fashion, as contesting parties articulate counter-frames to meet their opponents' preferred interpretations. Some of these find fertile ground in public discussion and thinking, while others do not."119 While the previous section has highlighted the degree to which audience agency plays a role in giving power to a frame, it is worthwhile to consider how frames themselves may work to

\footnotetext{
${ }^{115}$ Price et al., 181.

${ }^{116}$ Gamson and Modigliani, 1.

117 Gamson and Modigliani, 2.

118 Ibid.

${ }^{119}$ Price et al., 182.
} 
take hold of one's thinking in the first place. According to Chong and Druckman, within the realm of political science and communications, much focus has been on framing effects - that is, how frames in the communications of elites (i.e. politicians, interest groups, the media) influence citizens' frames and attitudes. ${ }^{120}$ Framing — the specific concept and term used to present choice or decision options - has been found to exert powerful effects on judgment and choice. ${ }^{121}$ Given the potential effect frames have on audience members' attitudes and behaviours, it is significant that attention be paid to them and that we reflect on their impact. Chong and Druckman provide some insight into both the mediational processes and the moderators that contribute to how framing effects work. Speaking to mediational processes, a mix of factors - including the strength and repetition of the frame (i.e. it is a concept familiar to an individual and is easily retrievable from memory), the competitive environment (i.e. it is a frame that is available, accessible, and applicable, and is viewed as relevant compared to other available ones), and individual motivations (i.e. if one is motivated, they will consciously evaluate competing considerations that either come to mind or are suggested by a frame, or people will be motivated to engage in a conscious evaluation when they are exposed to opposing consideration) contribute to the ultimate framing effect. ${ }^{122}$ With regard to moderators, individual predispositions, such as values, have been demonstrated as having a framing effect in several studies. ${ }^{123}$ Chong and Druckman put forth that, amongst individual predispositions, those that are strong reduce framing effects by increasing resistance to any information that does not confirm

\footnotetext{
${ }^{120}$ Chong and Druckman, 109.

${ }^{121}$ Iyengar, 1991.

${ }^{122}$ Chong and Druckman, 111.

${ }^{123}$ See, for instance: Paul R. Brewer, "Value words and lizard brains: Do citizens deliberate about appeals to their core values?," Political Psychology 22, no. 1 (2001): 45-64; David C. Barker, "Values, frames, and persuasion in presidential nomination campaigns," Political Behavior 27, no. 4 (2005): 375-394; Fuyuan Shen and Heidi Hatfield Edwards, "Economic individualism, humanitarianism, and welfare reform: A value-based account of framing effects," Journal of Communication 55, no. 4 (2005): 795-809.
} 
ones' preconceived beliefs; ${ }^{124}$ interestingly, even those who hold tight to their values are still susceptible to frames on issues that they have yet to determine a stance on. ${ }^{125}$ Another individual-level moderator is knowledge; Chong and Druckman argue that knowledge enhances framing effects given that the considerations being emphasized by that frame will be more comprehendible to an individual $^{126}$. Furthermore, other moderators that are external to one's self can aid in strengthening the applicability of a frame - here, the form of presentation, its resonance on an individual, and its existence in relation to other forms of information play a role. Frames delivered by credible sources have an increased change of shifting opinion; ${ }^{127}$ similarly, frames that provoke cultural values can also take more of a hold on an individual. ${ }^{128}$ What is more, the degree to which a frame is successful depends on whether other information and perspectives is available to the public. ${ }^{129}$

Indeed, this study aims to determine how the legalization of same-sex marriage was framed by Canadian national print newspapers and the factors that influenced them in an attempt to theorize their impact on public opinion. In analyzing the frames and their impact, the aforementioned insights will enable one to make sense of how frames come to be and the ways in which they may take hold on an individuals' conscious. This awareness, in conjunction with understanding the democratic potential of the public sphere, will allow for a deeper reflection of

\footnotetext{
${ }^{124}$ Chong and Druckman, 111-112.

${ }^{125}$ Ibid.

${ }^{126}$ Druckman, 112.

${ }^{127}$ James N. Druckman, “On the limits of framing effects: Who can frame?” Journal of Politics 63, no. 4 (2001): 1041-1066.

${ }^{128}$ Dennis Chong, Rational Lives: Norms and Values in Politics and Society (Chicago: University of Chicago Press, 2000).

${ }^{129}$ Vincent Price and Eun-Kyung Na, "Citizen deliberation and resistance to framing effects," in Annual Meeting of the American Association for Public Opinion Research, Portland, Oregon, May, pp. 18-21. 2000.
} 
how Canadian national print news was capable of affecting opinion on marriage equality in the nation.

\section{North American Print Media Practices}

The application of these theoretical concepts to the results of the original data collection becomes more profound when additional context is given. As such, the dissertation must investigate how Canadian national print news operates and reflect upon the degree to which this may have impacted the selection and framing of issues and the formation of public opinion.

Daniel C. Hallin and Paolo Mancini's comparative analysis of different media systems around the world led them to develop a conceptual framework that delineates models of media and politics. Based on the schematics of this framework, Canadian national print news operates within a "liberal" model of media. Media systems operating within this model - which are also be found in Britain, Ireland, and the United States - are characterized by the following: commercial newspapers dominate; political pluralism ${ }^{130}$ is low; internal pluralism ${ }^{131}$ is prevalent - with the important exception of the highly partisan British press; professionalization of journalism is relatively strong; journalistic autonomy is more likely to be limited by commercial pressures than political instrumentalization, though the latter is more common in Britain; information-oriented journalism predominates, although there is a strong commentary tradition in Britain; and the role of the state is limited, though more so in the United States than in Britain, Ireland, and Canada ${ }^{132}$.

Concern over the concentration of newspaper ownership within Canada's media system drove three investigations that sought to study the effect of this phenomenon on Canadians - the

\footnotetext{
${ }^{130}$ i.e. the degree to which the structure of the media system parallels that of the party system

131 i.e. covering different opinions and perspectives within one medium

132 Daniel C. Hallin and Paolo Mancini, Comparing Media Systems: Three Models of Media and Politics (New York: Cambridge University Press, 2004): 75.
} 
1970 Special Committee of the Senate on Mass Media (The Davey Report), the 1981 Kent Commission, and the 2006 Final Report on the Canadian News Media. ${ }^{133}$ Over the course of nearly four decades of investigations, the findings raised the same concern: the monopolization of media was a threat to the quality and health of Canada's democracy; corporate control was seen to restrict journalistic balance and fairness, set a narrow agenda of coverage, and reduce investment in newsgathering in an effort in maximize profits. In speaking to the state of concentration in Canadian media in the mid-2000s, the Final Report reveals that, "The current situation, with its strengths and weaknesses, is the result of a long and often difficult history of efforts by individuals to build strong and profitable news organizations, and the efforts of officials to deal with complex situations that do not lend themselves to one easy solution."134 However, in light of this, these reports all offer that change is necessary and within the government's grasp; indeed, the Final Report demonstrated that "while Canada has a number of regulations and programs designed to prevent foreign ownership of Canadian media, corresponding rules to prevent high levels of concentration of ownership of media properties, either in particular regions or within the country as a whole, do not exist"135; it also has had no forum to discuss mergers of news media organizations. ${ }^{136}$ This is surprising, since other developed nations, including the United Kingdom, France, Germany and the United States, all have legislation aimed at limiting dominant ownership positions within individual markets ${ }^{137}$. Ultimately, a plurality of owners is viewed as a necessary to ensure that different sources of

\footnotetext{
${ }^{133}$ It is worth noting that more than two decades passed between the Kent Commission and the Final Report; this can be attributed to the wave of consolidation that commenced in the late-1990s.

${ }^{134}$ Standing Senate Committee on Transport and Communications, Final Report on the Canadian News Media (Volume 1, June 2006), 63.

${ }^{135}$ Ibid.

${ }^{136}$ Standing Senate Committee on Transport and Communications, 64.

${ }^{137}$ Ibid.
} 
news and opinion are circulated, thereby maintaining a free press. ${ }^{138}$ To this end, the Final Report emphasized the urgency of amending Canadian policy when they concluded: "It is impossible to have democracy without citizens and impossible to exercise meaningful citizenship without access to news, information, analysis, and opinion... The public interest in healthy and vibrant news media is as important as the public interest in the rights and freedoms of individual citizens" ${ }^{\prime 39}$. Indeed, public policy is key to maintaining journalistic integrity; this is especially crucial when we consider the civic function of the news media, which Michael Schudson states includes: providing accurate information given so citizens can make sound political choices; investigating concentrated sources of power; helping citizens comprehend a complex world; informing citizens about others in their society and world so they can come to understand different perspectives; serving as a forum for groups in society to share their perspectives; and advocating for particular political programs and perspectives and mobilize people to support them. ${ }^{140}$ However, as Brian Gorman notes, despite these investigations on the concentration of ownership in Canada's newspaper industry and their implications on commerce and democracy, the recommendations given through these reports have been ignored (with the exception of the provincial press councils that audiences can reach out to should they witness media injustice $-\mathrm{a}$ product of the Davey Commission). ${ }^{141}$

Relating this to the case study under investigation, journalists writing for national newspapers in a post-Charter Canada were operating within a fairly concentrated newspaper

\footnotetext{
${ }^{138}$ Ibid.

${ }^{139}$ Standing Senate Committee on Transport and Communications, 65.

${ }^{140}$ Michael Schudson, Why Democracies Need an Unlovable Press (Malden, MA: Polity, 2008): 12.

${ }^{141}$ Brian Gorman, Crash to Paywall: Canadian Newspapers and the Great Disruption (Kingston: McGill-Queen's University Press, 2015), 68.
} 
industry; as Dwayne Winseck reveals in the Canadian Media Concentration Research Project's (CMCRP) Media and Internet Concentration in Canada Report, 1984-2017, Canada's newspaper industry saw a steady rise in concentration from 1984 until 2000, a period of decline during the first decade of the new millennium, and an increase once again since $2010 .{ }^{142}$ The CMCRP's report highlights the increase of concentration that has taken place within a thirty-year time period by showing that, in 1984, the biggest four newspaper ownership groups in Canada accounted for $64 \%$ of the newspaper industry's revenues; this figure would rise slowly and steadily to roughly two-third of the market by 1996 , and jumped exponentially by 2011 , with Postmedia, Torstar, Quebecor, and Power Corp/Gesca Media accounting for $81.6 \%$ of the market. ${ }^{143}$ The phenomenon of media concentration has raised much alarm amongst commentators, including C. Edwin Baker and Ben Bagdikian, who advance that a democracy needs many dissenting voices to have access to a public forum; the concentration of media ownership into a few hands makes it so that some voices are more likely to be heard than others as media owners are motivated by economic profit than public interest ${ }^{144}$; speaking to the benefits of weakened consolidation, Baker writes, "The key goal, the key value, served by ownership dispersal is that it directly embodies a fairer, more democratic allocation of communicative power" ${ }^{\text {"145 }}$ Responding to media consolidation in Canada specifically, David Taras echoes such concerns; Taras advances that the growth of huge media conglomerates in the nation contributes to the creation of a narrower and more limited media world. As a consequence, the capacity for the public sphere to be a space for the proliferation of new

\footnotetext{
142 Dwayne Winseck, Media and Internet Concentration in Canada Report 1984 - 2017 (Canadian Media Concentration Research Project, December 11, 2018): 58.

${ }^{143}$ Ibid.

${ }^{144}$ See C. Edwin Baker, Media Concentration and Democracy: Why Ownership Matters (New York: Cambridge University Press, 2007); Ben H. Bagdikian, The New Media Monopoly (Boston: Beacon Press, 2004).

${ }^{145}$ C. Edwin Baker, "Media Structure, Ownership Policy, and the First Amendment," Southern California Law Review 78 (2005): 735.
} 
messages and ideas become lessened, thereby weakening the health of democracy in the nation. ${ }^{146}$ In light of this, it is worthwhile to stress that, amidst such media consolidation in the time period under investigation, Canada's national newspapers were in competition with each other. The National Post, first established in 1998, was originally owned by Hollinger International, before being fully acquired by CanWest in $2001 .^{147}$ PostMedia then acquired the National Post in 2010 when CanWest entered bankruptcy. ${ }^{148}$ During the time period under investigation, The Globe and Mail, established in 1844, was owned by Thomson Corp. since 1980; Thomson Corp. transferred control of The Globe and Mail to Bell Canada in 2001, and with this, the paper was combined with Bell Canada's broadcast assets to form Bell Globemedia. ${ }^{149}$ This arrangement lasted over a decade until Thomson Corp., through Woodbridge, its holding company, reacquired full control of The Globe in $2015 .^{150}$ The Post's entry into the national newspaper scene caused much talk about a newspaper war, but this competition wielded the potential of diversifying the media landscape and causing for each paper to put forth their best journalism. William Thorsell, The Globe's editor-in-chief at the time of the Post's establishment, believed that the competition would prompt The Globe to better itself, stating, "Instead of dumbing down because there's someone else in the market, the papers are getting better." ${ }^{\prime 151}$ Commenting on the benefits of competition within Canada's newspaper

\footnotetext{
${ }^{146}$ David Taras, Power and Betrayal in the Canadian Media (Peterborough, Ont.: Broadview Press, 1999), 27.

${ }^{147}$ CBC Archives, "The Birth of the National Post and 'the Impending Newspaper War'," $C B C$, October 27, 2018, https://www.cbc.ca/archives/the-birth-of-the-national-post-and-the-impending-newspaper-war-1.4875372 (accessed June 17, 2019).

${ }^{148}$ The Canadian Press, "Postmedia Network Acquires Canwest's Newspaper Division," CTV, July 14, 2010, https://www.ctvnews.ca/postmedia-network-acquires-canwest-s-newspaper-division-1.532616 (accessed June 17, 2019).

${ }^{149}$ CBC News, "BCE Gets Green Light: Bell Globemedia born," CBC, January 9, 2001, https://www.cbc.ca/news/business/bce-gets-green-light-bell-globemedia-born-1.278218 (accessed June 17, 2019).

${ }^{150}$ Reuters, "Thomson family's Woodbridge buys full control of Globe and Mail," $C B C$, August 14, 2015, https://ca.reuters.com/article/businessNews/idCAKCN0QJ2AJ20150814 (accessed June 17, 2019).

${ }^{151}$ CBC Archives, "The Birth of the National Post and 'the Impending Newspaper War'," $C B C$, October 27, 2018 , https://www.cbc.ca/archives/the-birth-of-the-national-post-and-the-impending-newspaper-war-1.4875372 (accessed June 17, 2019).
} 
industry in 2006, Christopher Waddell, a professor at and former director of the School of Journalism and Communication at Carleton University in Ottawa, observed: "I believe that competition improves the quality of a product and that's just as true in the media as in any other business. The Globe and Mail, for instance, became a better newspaper when the National Post came on the scene to challenge it. The less competition there is, the less pressure there is to innovate, to try new ideas and approaches, to try to be better than someone else."152

Any assessment of the reporting of the legalization of same-sex marriage must take into consideration Canadian print media practices and concerns over media consolidation. Through this, we can reflect upon the degree to which Canadian national print news operated within known standards for their media system, as well as to what extent media consolidation might have affected the dynamism of such reports, and, subsequently, the diversity of ideas entering the public sphere. This analysis of the role national print news had informing public opinion on marriage equality can gain additional depth should it not only consider media practices, but also the historical treatment of LGBTQ issues within the pages of Canadian mainstream newspapers. To what extent did matters concerning LGBTQ peoples circulate within the Canadian public sphere? Which issues were made accessible? How were they presented? Indeed, an overview of historical representations of LGBTQ issues in Canadian national newspapers provides us with a baseline with which to compare and analyze the results of the data collection.

\section{The Treatment of LGBTQ People in Canadian Mainstream Press}

In an attempt to regain the normalcy and stability perceivably lost during the Second World War, North American society had targeted homosexuality as an instigator of social ills; in a moral panic, the homosexual was cast as the disruptor of traditional family life, a criminal

\footnotetext{
152 Sasha Nagy, "Mass Media," The Globe and Mail, July 13, 2006, https://www.theglobeandmail.com/opinion/mass-media/article24356794/ (accessed June 17, 2019).
} 
sexual psychopath with a penchant for children, and a figure prone to Communists' blackmailing - characteristics that placed homosexual individuals as a threat to both moral and national security. The communication of these ideologies through popular forms of print media was a rather recent phenomenon; according to Kathryn Campbell, "Prior to 1950, there was a virtual silence on the subject of homosexuality in North American media. Although there were occasional vague references to effeminate male actors and artists, homosexuality was considered too immoral to be mentioned in the media, and some newspapers and television stations even had explicit policies banning the subject." ${ }^{153}$ It was with the circulation and publicity surrounding Dr. Alfred Kinsey’s seminal texts, Sexual Behavior in the Human Male (1948) and Sexual Behavior in the Human Female (1953), that the discussion of sexuality in North American media, including newspapers and magazines, became legitimized ${ }^{154}$; indeed, Kinsey’s findings, which made claims of high rates of homosexuality amongst the population, served to "inform Canadian medical, psychological, and popular literature in the 1950s and 1960s."155 While the response to Kinsey's works may have validated the public discussion of homosexuality in print, it is imperative to stress that at this time in Canada, “...mainstream papers (e.g., Toronto Telegram; The Globe; Toronto Daily Star) generally shied away from topics like sex between men and 'sex perversion' more generally."156 Tom Warner expands on this when he writes: "for most of the immediate postwar period, the mainstream press in Canada paid virtually no attention to homosexuality or homosexuals. In fact, some mainstream newspapers, such as the Toronto Star, did not begin compiling news stories on homosexuality

\footnotetext{
${ }^{153}$ Campbell, 128.

${ }^{154}$ Gary Kinsman, The Regulation of Desire: Homo and Hetero Sexualities (Montréal, Qué.: Black Rose Books, 1996), 159.

${ }^{155}$ Kinsman, 159.

${ }^{156}$ Bart Sarsh, “'Disgusting' Noises, and 'Dangerous' Spaces: Tabloids, Sexualities, and Discourses of Perversion, Toronto, 1950-1962” (MA research paper, University of Toronto, 2005), 9.
} 
until the 1960s. Such stories as did appear were usually reports on murders or sexual offences, or dealt with deviancy, quoting the opinions of psychiatrists." ${ }^{, 157}$ Contrary to this, talk of homosexuality frequently filled pages of a form of alternative press as early as the late 1940s the Canadian tabloids (also known as "yellow journals," "yellow papers," and "scandal sheets"). Such publications were known for their sensationalist content, which was generally geared towards stories of scandal, crime, and gossip pertaining to public figures. ${ }^{158}$ National tabloids including Justice Weekly, Tab, Hush, True News Times, and Flash - often published pieces that spoke to the prevailing societal belief that any sexual orientation that deviated from heterosexuality was abnormal; as Bart Sarsh describes, "stories of 'gay orgies', lavatory sex, and male prostitution - to name but a few of the topics - were principally disseminated by the tabloids, which always reported on illicit stories from a heteronormative perspective."159 Considering that mainstream papers generally shied away from the topic, the tabloids were one of the few resources from which to gather information on homosexuality, thereby limiting one's exposure to this discourse found in entertainment (i.e. novels, magazines) and scientific literature.

While the Canadian mainstream press began publishing articles about LGBTQ people in $1964^{160}$, for the remainder of the twentieth century, the quantity of coverage was mostly scarce, and the treatment of the subject matter was capricious ${ }^{161}$; indeed, this time period was witness to

\footnotetext{
${ }^{157}$ Tom Warner, Never Going Back: A History of Homosexual Activism in Canada (Toronto, Ont: University of Toronto Press, 2002), 36.

${ }^{158}$ David Stewart Churchill, "Coming out in a Cold Climate: A History of Gay Men in Toronto During the 1950s" (MA thesis, University of Toronto, 1993), 49.

${ }^{159}$ Sarsh, 9-10.

${ }^{160}$ Warner, 36.

${ }^{161}$ Donald W. McLeod's chronology of the lesbian and gay liberation movement in Canada has been an invaluable resource to help determine how LGBTQ peoples were treated in Canadian mainstream print publications post-1964. See: Lesbian and Gay Liberation in Canada: a Selected Annotated Chronology, 1964-1975 (Toronto: ECW Press/Homewood Books, 1996), and Lesbian and Gay Liberation in Canada: a Selected Annotated Chronology, 1976-1981 (Toronto: Homewood Books, 2017).
} 
efforts to both maintain homophobic hysteria and challenge it. Mainstream press articles published in the 1960s were reflective of a Canadian society that still sought to study, monitor, police, and correct homosexuality. For instance, 1964 saw the publication of two print pieces that took starkly different perspectives in their discussion of gay life. Maclean's published a two-art series entitled, "The Homosexual Next Door: A Sober Appraisal of a New Social Phenomenon, ${ }^{, 162}$ considered to be the first mainstream pieces in a Canadian publication to approach the subject matter positively; ${ }^{163}$ by comparison, later that same year, The Toronto Telegram published a series of three articles describing the 'shadow world' inhabited by gay people that emphasized their perceived deviance and unhealthiness. ${ }^{164}$ The subject of questioning the origins of homosexuality and seeking to control and eradicate it was the subject of two pieces featured in 1966. The Toronto Daily Star dedicated two columns in their "What Should I Do?" advice series on the topic of homosexuality; ${ }^{165}$ questions were concerned with whether discussing homosexuality encourages it, and how to determine if someone was gay; responses to the queries stressed medical and psychiatric intervention for the 'homosexual problem'. Similarly, Chatelaine featured an article, "What Turns Women to Lesbianism?", that cited medical researchers in an effort to offer explanations for the causes, frequency, and treatment of lesbianism. ${ }^{166}$ Police concern about homosexual activity was also mentioned in print; in 1964, in

\footnotetext{
${ }^{162}$ Sidney Katz, "The Homosexual Next Door: A Sober Appraisal of a New Social Phenomenon," Maclean's, 22 February 1964, p. 10-11, 28-30; Sidney Katz, “The Harsh Facts of Life in the 'Gay' World," Maclean's, 7 March 1964, pp. 18, 34-38.

${ }^{163}$ Donald W. McCleod, Lesbian and Gay Liberation in Canada: a Selected Annotated Chronology, 1964-1975 (Toronto: ECW Press/Homewood Books, 1996), 3.

${ }^{164}$ Ron Poulton, "Society and the Homosexual" (part i), Toronto Telegram, final ed., 11 April 1964, p. 7; Ron Poulton, "The Sick Life" (part 2), Toronto Telegram, final ed., 14 April 1964, p. 7; Ron Poulton, "Church and Law" (part 3), Toronto Telegram, final ed., 15 April 1964, p. 7.]

${ }^{165}$ Sidney Katz, “What Should I Do?: Does Discussing Homosexuality Encourage It?”(column), Toronto Daily Star, night ed., 15 September 1966, p. 3; Sidney Katz, "What Should I Do?: How Can I Tell If My Son, 12, Is Homosexual?" (column), Toronto Daily Star, night ed., 17 September 1966, p. 3.

${ }^{166}$ Renate Wilson, "What Turns Women to Lesbianism?" Chatelaine, October 1966, p. 33, 130-32, 134.
} 
his weekly column in the Toronto Daily Star, Nathan Cohen mentioned that Toronto police worried that hangouts for homosexuals had reopened. ${ }^{167}$ Later that year, fellow columnist Michael Hanlon wrote in The Globe and Mail that Toronto police were fretting about the increasing popularity of local gay clubs, and how that the club customers' "proper" behavior meant that no charges could be laid. Hanlon opined that cops were not so much worried about the activities taking place, but that the existence of these clubs meant that homosexuality had a chance to thrive. ${ }^{168}$ That said, while rare, attempts were made by newspapers to make visible voices that supported the LGBTQ community. However, one such attempt was met with heavy censorship, demonstrating an unwillingness on the part of several newspapers to dedicate coverage that was positive towards gay people. In 1964, the Vancouver Sun published a piece written by a Vancouver-based Anglican priest in which he advocated for equal treatment for all, regardless of homosexuality, and law reform in response to anti-gay laws in the nation; ${ }^{169}$ five years later, a four-page article profiling Paul Bédard, founder of the Gemini 1 Club (a private social club for lesbians and gays) and president of International Sex Equality Anonymous (an educational and social homophile organization), was meant to appear in the Weekend magazine supplement of thirty-nine Canadian newspapers; ${ }^{170}$ however, fourteen of those papers tore out or refused to include the supplement.

A combination of events that took place in particularly in the mid-late 1970s and into the early 1980s created a tumultuous environment that was witness to both displays of hostility and compassion by the Canadian mainstream press towards LGBTQ people and issues. The Body

\footnotetext{
${ }^{167}$ Nathan Cohen, "Monday Miscellany” (column), Toronto Daily Star, night ed., 13 January 1964, p. 18.

${ }^{168}$ Michael Hanlon, "Homosexual Clubs Worry Metro Police" (column). Globe and Mail, metro edition, 5 August 1964, p. 8.

${ }^{169}$ William Nicholls, "Homosexuality: Changing the Laws Could Raise Morality," Vancouver Sun, four star ed,, 6 July 1965 , p. 6.

${ }^{170}$ William Spencer, “Canada's Leading Homosexual Speaks Out,” Weekend Magazine, 13 September 1969, p. 6-8.
} 
Politic, Canada's leading gay periodical, sparked controversy upon the publication of three articles addressing adult-child sexuality: Gerald Hannon's "Of Men and Little Boys," in 1972, "Outrage" in 1975, and "Men Loving Boys Loving Men," in 1978; this reinforced homophobic hysteria about pedophilia within the media, ${ }^{171}$ and even prompted the Toronto Star to, for a time, not only refuse to include advertisements in support of The Body Politic, ${ }^{172}$ Glad Day Bookshop, ${ }^{173}$ and the Community Homophile Association of Toronto (CHAT) ${ }^{174}$ but also publicly question the intentions of the gay liberation movement in an editorial. ${ }^{175}$ Another derogatory stereotype - 'the homosexual as 'deviant criminal' - saw itself reinforced, and even went so far as to publicly name and shame those involved. Media coverage of an Ottawa-based modelling agency that was used as a front for a prostitution ring revealed the names of all those charged. ${ }^{176}$ Similarly, in reporting of bathhouse raids in $1977^{177}$ and 1978, media coverage published highly sensationalized reports that released the personal information of those involved, causing humiliation and social censure for those arrested while simultaneously projecting an image of the police protecting citizens from a 'societal threat'. ${ }^{178}$ What is more, the sexual assault and murder of twelve-year shoeshine boy Emanuel Jaques at a body-rub parlour was so sensationalized in Canadian mainstream media that Borden Spears, a senior editor at the Toronto Star, proclaimed that the media coverage was unprofessional and tasteless ${ }^{179}$.

Mainstream print media's approach to LGBTQ peoples and legal matters adjusted somewhat once activists began fighting for amendments to provincial human rights codes in an

\footnotetext{
${ }^{171}$ Warner, 150.

${ }^{172}$ McLeod, Lesbian and Gay Liberation in Canada: a Selected Annotated Chronology, 1964-1975, 119, 156,

${ }^{173}$ McLeod, Lesbian and Gay Liberation in Canada: a Selected Annotated Chronology, 1964-1975, 168.

${ }_{174}$ McLeod, Lesbian and Gay Liberation in Canada: a Selected Annotated Chronology, 1964-1975, 150.

175 "Homosexuals: Where the Star Draws the Line" (editorial), Toronto Star, Saturday ed., 19 October 1974, p. B2

${ }^{176}$ Warner, 103-104.

${ }^{177}$ McLeod, Lesbian and Gay Liberation in Canada: a Selected Annotated Chronology, 1976-1981, 115.

${ }^{178}$ Warner, 104.

${ }^{179}$ McLeod, Lesbian and Gay Liberation in Canada: a Selected Annotated Chronology, 1976-1981, $159-160$.
} 
attempt to acquire protection against discrimination on the basis of sexual orientation. While Quebec's amendment to their human rights protections in 1977 was not well covered in the mainstream press, ${ }^{180}$ the Ontario Human Rights Commissions' report on ways to improve Ontario's Human Rights Code, released that same year, garnered mixed responses by the media; entitled Life Together, the report recommended that sexual orientation be included in the Ontario Human Rights Code as a prohibited ground of discrimination. Months later, The Globe and Mail's provincial affairs columnist discussed amending Ontario's human rights legislation, including caricatures and assumptions about gay people. ${ }^{181}$ When the Coalition for Gay Rights in Ontario offered a press conference at the Ontario Legislature to present its brief, Discrimination and the Gay Minority, to the media in Spring 1978, their reaction was once again mixed ${ }^{182}$; for instance, both The Globe and Mail ${ }^{183}$ and Toronto Star ${ }^{184}$ were supportive of including sexual orientation in Ontario's Human Rights Code, while the Toronto Sun was not. ${ }^{185}$

As a new decade began, mainstream presses began to demonstrate signs of compassion towards LGBTQ-interests. Notably, in 1980, amidst the trials of The Body Politic, The Globe and Mail ran a full-page ad in its pages for the Body Politic Free the Press Fund, which read: "We urge the Attorney-General of Ontario to drop the appeal against The Body Politic"; this was a landmark moment, for it was the first time a Canadian daily paper published an advocacy ad for a gay cause. ${ }^{186}$ This was particularly significant considering The Globe previously demonstrated hesitation towards openly discussion of homosexuality. In 1977, The Globe had refused to print an advertisement seeking to raise funds for the Committee to Defend John

\footnotetext{
${ }^{180}$ McLeod, Lesbian and Gay Liberation in Canada: a Selected Annotated Chronology, 1976-1981, 206.

${ }^{181}$ McLeod, Lesbian and Gay Liberation in Canada: a Selected Annotated Chronology, 1976-1981, 231.

${ }^{182}$ McLeod, Lesbian and Gay Liberation in Canada: a Selected Annotated Chronology, 1976-1981, 273.

${ }^{183}$ Norman Webster, "Hot Topic Coolly Handled," Globe and Mail, metro ed., 18 May 1978, p. 7.

184 “Minorities Have Civil Rights as Well” (editorial), Toronto Star, Saturday ed., 20 May 1978, p. C2.

${ }^{185}$ Claire Hoy, "Homosexuals Far from Harmless" (column), Toronto Sun, 18 May 1978, p. 34.

${ }^{186}$ McLeod, Lesbian and Gay Liberation in Canada: a Selected Annotated Chronology, 1976-1981, 497.
} 
Damien because the paper did not want to accept an ad for an issue that was not only currently before the courts, but also referred to the reasons for Damien's discrimination (i.e. his sexuality ${ }^{187}$; additionally, under pressure from CGRO, in 1979, The Globe and Mail allowed the word 'gay' as opposed to 'homosexual' to be featured in personal classified advertisements published in paper. ${ }^{188}$ Furthermore, in 1981, not only did all three Toronto dailies agree not to publish the names of those arrested in the February $5^{\text {th }}$ Toronto bathhouse raids, ${ }^{189}$ but mainstream print publications began raising critical questions about Operation Soap - especially since they were forced to take into account the huge mass demonstrations that were organized by activists in light of it. ${ }^{190}$ That said, this spirit of open-mindedness halted with the arrival of the AIDS crisis. The year 1981 saw the first media reports about AIDS in the United States, filling the public consciousness with accusations that this 'gay plague' resulted from perceived promiscuity and drug use within the gay community, which was thought to have proliferated in the wake of the lesbian and gay liberation movement. ${ }^{191}$ The Canadian presses subsequently adopted similar language and perspectives. ${ }^{192}$ However, more compassionate media exposure emerged when individuals began publicly revealing their suffering from the disease, bringing humanity on a much-feared disease. Beginning in 1983 with coverage of Peter Evans, the first Canadian to speak openly about having AIDS, ${ }^{193}$ the narrative shifted from one of fear and panic to increasing empathy. ${ }^{194}$ In conjunction with this, the pursuit of legislative changes across the nation by activists helped to create awareness amongst the public and the media about the dire

\footnotetext{
${ }^{187}$ McLeod, Lesbian and Gay Liberation in Canada: a Selected Annotated Chronology, 1976-1981, 153.

${ }^{188}$ McLeod, Lesbian and Gay Liberation in Canada: a Selected Annotated Chronology, 1976-1981, 458.

${ }^{189}$ McLeod, Lesbian and Gay Liberation in Canada: a Selected Annotated Chronology, 1976-1981, 626.

${ }^{190}$ Gary Kinsman (Queer and Anti-Capitalist Activist, researcher) in discussion with the author, November 2018.

${ }^{191}$ Warner, 161.

192 Warner, 163.

193 Ibid.

${ }^{194}$ Tim McCaskell (former member of The Body Politic, founding member of AIDS ACTION NOW!) in discussion with the author, October 2018.
} 
consequences of discrimination. As the demand and fight for equal treatment became more pronounced - particularly after Human Rights Codes across the nation changed - the presence of LGBTQ concerns in newspapers became more frequent, more fair and more neutral. ${ }^{195}$ Gary Kinsman advances that the fight for protection against discrimination, and subsequent efforts to achieve spousal benefits and family recognition, signified to the general public and journalists that lesbians and gay men desired to be 'let in'; the absence of a 'radical' agenda being advanced and an assimilationist attitude on the part of most activists is thought to have been a major contributor to media's gradual shift in treatment. ${ }^{196}$

Witnessing the legal, legislative, and health battles fought by the Canadian LGBTQ community, national mainstream newspapers came to realize that these battles were reasonable to support, as they did not risk disrupting the status quo. Subsequently, the national print press began approaching LGBTQ-related issues seriously, reporting on them with increased fairness. As a result, the public sphere began to be infused with increasingly balanced perspectives on these issues, allowing for individuals to make better informed opinions about them. Would this change once the demand for marriage equality became a pressing concern for many activists? The following chapter closely analyzes the results of the content analysis of articles discussing same-sex marriage published in The Globe and Mail and the National Post post-Charter to determine the frequency and treatment of this issue, and will further contextualize the creation of these pieces through the results of semi-structured interviews with some of the journalists involved in developing them.

\footnotetext{
${ }^{195}$ Tom Warner (gay rights activist, former Human Rights Commissioner) in discussion with the author, November 2018.

${ }^{196}$ Gary Kinsman (Queer and Anti-Capitalist Activist, researcher) in discussion with the author, November 2018.
} 


\section{Chapter 3: Writing for the Mainstream}

\section{$\underline{\text { Introduction }}$}

Delvin Vriend's legal challenge of the Alberta government's refusal to extend antidiscrimination legislation to gay Albertans reached new heights in November 1997, when his case went before the Supreme Court of Canada; this was yet another crucial moment in the fight for LGBTQ equality in the nation, for the outcome could not only lead to the expansion of human rights protection in yet another province, but become another victory amidst nearly a decade of incremental policy gains. Word of the upcoming Supreme Court Case intrigued Janice Tibbetts, who, at the time, was a reporter for The Canadian Press in Ottawa, working out of their Parliamentary Bureau. She transferred from the agency's Edmonton office earlier that year, and, having previously covered Alberta Legislature for the news agency, wrote about Vriend throughout the early 1990s. From her reporting on the Vriend case, as well as following the battles for equality that had taken place within the nation, Tibbetts became invested in the advancement of gay rights; she believed in fairness, and was interested in seeing how this fight for equality would play out in Canada. Tibbetts brought this curiosity with her to Ottawa, pitching the upcoming Supreme Court case to her assignment editor, suggesting it would be a worthwhile story to report on. The editor replied that this event and its potential outcomes didn't affect very many Canadians, and, consequently, they were not interested in stories about it. Despite this initial resistance, Tibbetts held firm that Vriend's case was a necessary story to tell; Tibbetts recalls, "I pushed this onto our agenda at The Canadian Press because I said, 'Maybe this does affect a couple of people, but it does affect us as a society'...I pushed that onto our coverage, onto our agenda as opposed to just, I guess, ignoring it, which a lot of [journalists] in Ottawa were doing at the same time, because...a lot of [journalists] were interested in politics, 
and not what was happening in the courts." ${ }^{\prime 197}$ After the Vriend case, by continuing to pay attention to what was happening in the courts, Tibbetts was able to get on top of the issue of same-sex marriage earlier than other journalists - even after her move to the Southam Inc. news agency in 1998, where she became a justice reporter. Tibbetts believed that the debate surrounding gay rights in general, and same-sex marriage in particular, was not going to die down anytime soon, and that it was a necessary phenomenon to bring to people's attention. ${ }^{198}$ However, within her milieu of covering Parliament Hill in Ottawa, the prospect of legalizing same-sex marriage in Canada seemed like a hypothetical to her fellow journalists, so reporters were not paying much attention it; indeed, she was disappointed when, in June 2003, her article for CanWest News Service ${ }^{199}$ about an event she felt made for a huge story - an all-party parliamentary committee advancing that Justice Minster Martin Cauchon should not appeal an Ontario Court of Appeal decision that had recently legalized gay marriage - did not make the front page of the National Post. However, she was driven to keep covering developments in the bid for marriage equality in Canada, as she knew it was “.....an enduring debate and [it was not] going anywhere because you could see what was happening in the courts. You could see that this was eventually going to be pushed onto the political agenda as well.,200

The anecdote above raises questions about the coverage of same-sex marriage in Canadian national newspapers that this chapter aims to address. When it came to believing that the fight for marriage equality was a newsworthy issue, was Tibbetts an outlier amongst her journalist peers on Parliament Hill? Were other journalists just as intrigued, but were prevented to pursue such stories due to standards of practice or assigned roles that caused for their attention

\footnotetext{
${ }^{197}$ Janice Tibbetts (Journalism Instructor, Carleton University) in discussion with the author, October $29^{\text {th }}, 2018$.

198 Ibid.

${ }^{199}$ Janice Tibbetts, "MPs Vote to Drop Appeal of Same-Sex Ruling”, National Post, 13 June 2003, A7.

${ }^{200}$ Janice Tibbetts (Journalism Instructor, Carleton University) in discussion with the author, October $29^{\text {th }}, 2018$.
} 
to be directed elsewhere? If, as Tibbetts suggests, marriage equality was not a major concern amongst the journalist reporting from Parliament Hill, when and how did it appear in the Canadian national presses, and to what extent was it featured in their pages? Would the newsworthiness of this issue heighten over time, thus grabbing the attention of journalists who had previously dismissed its importance? What was involved in the construction of articles about the legalization of same-sex marriage for Canadian national newspapers? How did these articles frame marriage equality? That said, the purpose of this chapter is to reveal the extent to which marriage equality was covered by Canadian national newspapers, how this subject matter was framed and why this was, and whether or not this coverage abided by known journalistic standards. The evidence included herein not only brings to light how this issue was treated by Canadian national newspapers, but serves as a point of departure to consider what information was disseminated to readers, and how this might have affected their opinion. Based on the results of the content analysis and the semi-structured interviews, this chapter argues that the newsworthiness of marriage equality in Canada correlated to the seriousness with which Canadian courts and legislatures treated same-sex marriage and the political tensions that accompanied this. Viewed as a legitimate controversy, coverage of marriage equality in the nation by national print newspapers abided by journalistic standards of fairness and balance. Opinion-based coverage dominated both The Globe and Mail and the National Post, which included the frame utilized by supporters and the courts (equal rights) and that of their opponents (traditional values). Frames appeared in each paper to varying degrees, but were nonetheless accompanied by consistently neutral news stories. As a result, readers of each paper were exposed to both accurate updates on the state of marriage equality in Canada and current debates on the issue - information that could undoubtedly be used to inform both their knowledge and 
opinion of the matter; notably, given that the presence of frames were disproportionate particularly in The Globe and Mail - that publications' preferred frame had a better chance of taking root with readers.

\section{Journalism Ethics and Standards}

In order to fully comprehend the circumstances that informed the creation of stories on the topic of same-sex marriage, it is necessary to discuss the principles of ethics and good practice that supported Canadian journalists at this time. Yavuz Baydar asserts that codes of ethics (also known as ethics standards, ethics charters, codes of conduct, and codes of practice) are the core of media self-regulation, safeguarding the autonomy of the profession and working in the public's interest. ${ }^{201}$ These regulations are necessary because, in democracies, freedom of the press is entrenched in legislation, and journalists and media outlets benefit from the rights and privileges granted by it; in response, journalists must act responsibly, operating within transparent guidelines. ${ }^{202}$ At their core, codes serve as a point of reference for journalists, outlining their rights and obligations, and in the process, assert a standard against which their work can be accessed; they also benefit media owners and publishers, offering protection against legal action and criticism. ${ }^{203}$ Cumulatively, through standardizing good journalism, the interests of the public are attended to; following guidelines ensures that news is accurate, fair and balanced, and reliable, which benefits readers. ${ }^{204}$ That said, codes differ significantly from country to country based on various traditions of journalism vary, the development and amendment of guidelines take place at varying rates, and differing sensitivities within every

\footnotetext{
${ }^{201}$ Organization for Security and Co-operation in Europe (OSCE), The Media Self-Regulation Guidebook (Office of the Representative on Freedom of the Media, 2008), 21.

${ }^{202}$ OSCE, 22.

${ }^{203}$ OSCE, 22-23.

${ }^{204}$ OSCE, 22-23.
} 
society informing the presence, as well as the content, of such codes. ${ }^{205}$ The nonexistence of a singular code of ethics for journalism enables news outlets and professional organizations to develop their own guidelines as a resource to journalists.

In the Canadian context, ethics guidelines are set by news organizations, such as The Canadian Press (TCP), and associations, such as the Canadian Association of Journalists $(\mathrm{CAJ}) .{ }^{206}$ Through understanding their existence and their impact on journalists we can better interpret the guidelines followed by Canadian journalists. To begin, TCP published its first comprehensive style guide in 1940, comprising, as media scholar Gene Allen states, "a clear manifestation of TCP's growing concern with consistency and clarity in style, along with systematization of the news operation." ${ }^{, 207}$ Indeed, this initial style guide represented an early effort to explicitly outline preferred journalistic practices, rather than having them shared informally ${ }^{208}$; accuracy, impartiality, and reliability were regarded as cardinal virtues put forth by TCP at the time ${ }^{209}$. However, from the 1970 s onwards, in light of criticisms of objectivity and changing journalistic attitudes, TCP loosened its stance on traditional notions of objectivity, stressing fairness and balance in its place. ${ }^{210}$ The desire to uphold standards of practice became more pressing once freedom of the press became prominently placed within the nation's Charter of Rights and Freedoms in 1982. The second section of the Charter, titled Fundamental Freedoms, includes 'freedom of the press and other media of communication'. ${ }^{211}$ Bruce Gillespie reminds us that this Charter right promotes journalistic independence; not only can anyone in

\footnotetext{
205 OSCE, 24.

${ }^{206}$ Ivor Shapiro, "Codes of Ethics," accessed May 25 $5^{\text {th }}, 2019$, https://j-source.ca/article/codes-of-ethics/.

${ }^{207}$ Gene Allen, Making National News: A History of Canadian Press (University of Toronto Press, 2013 ), 278.

208 Ibid.

${ }^{209}$ Allen, 277-282.

${ }^{210}$ Stephen J. A. Ward, The Invention of Journalism Ethics: The Path to Objectivity and Beyond (Montreal: McGillQueen's University Press, 2015), 273.

${ }^{211}$ Constitution Act, 1982. https://laws-lois.justice.gc.ca/eng/const/page-15.html.
} 
Canada become a journalist or create a news outlet without state interference, but content creators have sole choice of what they wish to publish. ${ }^{212}$ That said, the law does not provide special rights to reporters; journalists are held to the same laws as other Canadians. ${ }^{213}$

Furthermore, if harkening back to what Baydar states, taking into consideration these rights and privileges given by their government, Canadian journalists have a duty to be transparent in how they conduct their business. Indeed, this was acknowledged in the ethics guidelines for the CAJ's first code of conduct in 2002; in its statement of principles, it is mentioned: "A free flow of information sustains and vitalizes democracy because understanding emerges from vigorous discussion, openly reported. Our legal traditions give media privilege and protection. We must return this trust through the ethical practice of our craft." ${ }^{, 214}$ This initial code of ethics covered fairness, accuracy, privacy, access, discrimination, polls, copyright and plagiarism, journalistic independence, conflict of interest, police, and journalistic criminal offenses. ${ }^{215}$

For the purposes of this dissertation, it is worthwhile to examine what constituted fairness and accuracy, using the CAJ's code of ethics as a guideline. For the CAJ, fairness and accuracy meant that biases would not influence reporting, conflicts of interests would be disclosed, allowing those criticized in a report the chance to present their points of view prior to publication, respecting people's civil rights, and not misleading the public through manipulation of any content. ${ }^{216}$ Notably, the committee that drafted the statement and accompanying ethical guidelines did not advance objectivity as a possible principle or guideline, emphasizing related

\footnotetext{
${ }^{212}$ Bruce Gillespie, News Writing and Reporting: An Introduction to Skills and Theory (Don Mills, Ontario: Oxford University Press, 2018), 143.

${ }^{213}$ Ibid.

${ }^{214}$ Accountable Journalism, "Canada: Canadian Association of Journalists Principals for Ethical Journalism," Accountable Journalism, accessed May 23 ${ }^{\text {rd }}, 2019$, https://accountablejournalism.org/ethics-codes/Canada-CAJPrinciples.

${ }^{215}$ Ibid.

${ }^{216}$ Ibid.
} 
concepts, including accuracy, credibility, fairness, and independence ${ }^{217}$; this was done given the ambiguous status of objectivity in journalism at the time. As Stephen J.A. Ward stresses, it is not that journalists outright reject objectivity, but that they believe the concept benefits from a loosening up. Indeed, pure objectivity can restrict good storytelling and strong journalism, as it assumes complete detachment and thus a lack of motivation and passion. ${ }^{218}$ The CAJ's ethics guidelines remained untouched until 2011, when they were revised. This is critical to highlight, as these were the guidelines available to the journalists writing the stories included in this dissertations' sample. Critically, taking into account these revisions, according to Ivor Shapiro, the CAJ's codes of ethics “...provide a reference point for what its authors perceive to be a broad consensus." 219 These guidelines, Shapiro stresses, are meant to highlight industry norms, not assert specific rules, and should be viewed both as a beginner's guide to best practices and a resource to be continually consulted to help address any issue that may arise. ${ }^{220}$ Ultimately, these efforts to instill ethics guidelines in the profession reflect an overall 'occupational ideology' in the field of journalism to remain as fair and balanced as possible. ${ }^{221}$

Considering the aforementioned discussion, we can expect that the Canadian journalists who were reporting on the legalization of same-sex marriage operated within such an occupational ideology, as is upheld by both Canadian standards and general journalistic practices. That said, while codes of conduct serve to outline professional norms and how journalists function to create stories, they do not articulate what is to become news; in other

\footnotetext{
${ }^{217}$ Ward, 272.

${ }^{218}$ Ward, 272-273.

${ }^{219}$ Lauren McKeon, “A Guide, Not a Cop: the CAJ's New Ethics “Code” (And Why It's Not Called That)," accessed May 25 ${ }^{\text {th }}, 2019$, https://j-source.ca/article/a-guide-not-a-cop-the-cajs-new-ethics-code-and-why-its-notcalled-that/.

${ }^{220}$ Ibid.

${ }^{221}$ See, for instance: Mark Deuze, "What Is Journalism? Professional Identity and Ideology of Journalists Reconsidered," Journalism 6, no. 4 (2005): 442-464; Bill Kovach and Tom Rosenstiel, The Elements of Journalism: What Newspeople Should Know and the Public Should Expect (New York: Three Rivers Press, 2014).
} 
words, now having an understanding of the journalistic norms that inform standards of practice, how do news organizations determine what is worth presenting to the public in the first place? An awareness of the practice of determining newsworthiness gives us some insight into why the issue of same-sex marriage came to be reported on in the first place, at the time that it did.

\section{The Construction of News Stories}

Bruce Gillespie states that the ability to judge what is newsworthy is imperative in journalism for all involved in the news room - "from the reporters and chase producers whose job it is to pitch story ideas to the editors and executive producers who are responsible for approving those ideas and deciding which get published or aired - deciding, ultimately, what becomes 'the news." ${ }^{\prime 222}$ Crucially, there are few fixed rules in the newsworthiness process; general guidelines do exist, but there is flexibility here, with room for discussion and disagreement. ${ }^{223}$ Indeed, according to Gillespie, assessing newsworthiness is a skill that is acquired tacitly through reading, watching, and listening to a range of news stories and determining their commonalities, as well as through pitching and debating story ideas. ${ }^{224}$

That said, there are noted paradigms for how the news selection process takes place. To begin, back in 1965, Johan Gatlung and Mari Holmboe Ruge offered a taxonomy of news values, which included: frequency (i.e. "the more similar the frequency of the event is to the frequency of the news medium, the more probably that it will be recorded as news by that medium"225), threshold (i.e. the more intense an event, the more impact it is perceived to have), unambiguity (i.e. an event can be understood clearly with little chance of misinterpretation), meaningfulness

\footnotetext{
${ }^{222}$ Gillespie, 73

${ }^{223}$ Ibid.

${ }^{224}$ Ibid.

${ }^{225}$ Johan Galtung and Mari Holmboe Ruge, "The Structure of Foreign News the Presentation of the Congo, Cuba and Cyprus Crises in Four Norwegian Newspapers," Journal of Peace Research 2, no. 1 (1965): 66.
} 
(i.e. culturally similar content is prone to be selected, for it adheres to the frame of reference of the news entity), consonance (i.e. a news outlet may want or predict for a particular occurrence to happen, and select items that increases the chances of this happening), unexpectedness (i.e. the event is rare), continuity (i.e. once an event becomes picked up by the media, it will continue to receive coverage), composition (i.e. the event contributes to a balanced overall news report) elite- centered (i.e. actions of elite nations or people are perceived to having more impact), personification (i.e. addressing actors by name means the event has more consequence, rather than referring to 'social forces'), and the negative (i.e. it tends to fulfill the previously mentioned criteria more than positive news). ${ }^{226}$ In 2001, Tony Harcup and Deirdre O’Neill proposed a contemporary set of news values as a means to contribute to the process of making news values more transparent; their criteria include: power elite (i.e. stories about those powerful individuals, organizations, or institutions), celebrity (i.e. stories about the famous), entertainment (i.e. stories about show business, human interest, humour, etc.), surprise, bad news, good news, magnitude (i.e. stories deemed significant due to numbers of people involved or perceived impact), relevance, follow-up (i.e. stories about things already being in the news), and newspaper agenda (i.e. stories that set or it the news organizations own agenda). ${ }^{227}$ What's more, since the early 1990s, Pamela J. Shoemaker et al. have developed a bio-cultural theory of news that serves to explain why an event becomes news ${ }^{228}$; here, deviance (i.e. calling to attention events that are above or below average occurrences), social significance (i.e. information needed to live as an effective citizen), complexity (the increased inclusion of deviance and social significance), and

\footnotetext{
${ }^{226}$ Galtung and Ruge, 65-71.

227 Tony Harcup and Deirdre O'Neill. "What Is News? Galtung and Ruge Revisited,” Journalism Studies 2 , no. 2 (2001): 278-279.

${ }^{228}$ Pamela J Shoemaker et. al, "Readers as Gatekeepers of Online News: Brazil, China, and the United States," Brazilian Journalism Research 6, no. 1 (2011): 58.
} 
personal relevance (i.e. considering what content audiences will identify with) are deemed news values. ${ }^{229}$ More recently, Tim Harrower listed a few values that qualify a story as news: impact, immediacy, proximity, prominence, novelty, conflict, emotions ${ }^{230}$; Gillespie suggest that merely making selections based on whether coverage is significant, interesting, and new - an oftenquoted rule of thumb for journalists that considers major agreed-upon characteristics of news - is not complex enough, as it does not explore the decision-making process enough (i.e. how is significant measured? Who is the event interesting to? When did the subject become news?). ${ }^{231}$ With this in mind, Gillespie offers that newsworthiness be determined using the PRINT test, which covers five main characteristics of newsworthiness: proximity, rareness, importance, newness, and tension. ${ }^{232}$

According to Michael Schudson, "journalists, well aware of the formal and informal norms of professional practice, are less cognizant of the cultural traditions that specify when and how professional norms are called into play., ${ }^{233}$ Through his concept of journalistic spheres, Daniel C. Hallin reveals the process of determining what receives media coverage and how the subject matter will be treated as one can be more concerned with maintaining reigning societal values than consistently abiding by occupational standards; through this, Hallin's spheres demonstrate the power journalists have to validate groups or issues while dismissing others. Hallin states, "it is useful to imagine the journalist's world as divided into three regions, each of which is governed by different journalistic standards." ${ }^{, 234}$ The first region- the Sphere of

\footnotetext{
${ }^{229}$ Shoemaker et al., 58-61.

${ }^{230}$ Tim Harrower, Inside Reporting: A Practical Guide to the Craft of Journalism, $6^{\text {th }}$ ed. (New York: McGraw-Hill, 2010), 19.

${ }^{231}$ Gillespie, 73-74.

${ }^{232}$ Gillespie, 74-80.

${ }^{233}$ Michael Schudson, The Power of News (Cambridge, Mass.: Harvard University Press, 1995), 13.

${ }^{234}$ Daniel C. Hallin, The "Uncensored War": The Media and Vietnam (New York: Oxford University Press, 1986), 116.
} 
Legitimate Controversy - is the realm of objectivity and balance that sees both sides of a mainstream political or legislative issue be debated. ${ }^{235}$ The second region - the Sphere of Consensus - concerns subject matter deemed noncontroversial by journalists; topics present in this realm are those that the majority agree on, and as such, do not need to be approached in a disinterested manner, but can instead be celebrated or championed by the journalist in their reporting. ${ }^{236}$ The third region - the Sphere of Deviance - is reserved for "those political actors and views which journalists and the political mainstream of society reject as unworthy of being heard"237; here, journalists regulate the public agenda and maintain the status quo by exposing, condemning, or excluding that which deviate or challenge political consensus. ${ }^{238}$ Thus, according to Hallin's theory, journalistic objectivity is not consistently upheld in practice; it is swayed depending by the perceived legitimacy of the issue being covered. When both sides of an issue are disseminated in the media, a reader may become educated enough to form their own opinion; this is only made possible for those issues deemed suitable for the Sphere of Legitimate Controversy, and not for 'deviant' subject matter. Through this, Hallin prompts us to consider the ways in which media may legitimize specific communities, ideologies, and issues, thereby preventing a full range of perspectives from entering the public sphere.

As this chapter has demonstrated so far, the process of transforming a current event into a news story is a complex one, influenced by known professional standards and practices and unintentional biases; this knowledge enables us to more accurately argue what circumstances prompted marriage equality to appear in Canadian national newspapers, and what the quantity, frames used, and article type featured reveals about how journalists and their editors perceived

\footnotetext{
235 Ibid.

${ }^{236}$ Hallin, 116-117.

${ }^{237}$ Hallin, 117.

${ }^{238}$ Ibid.
} 
and chose to present the issue. That said, in order to better contextualize the results of the content analysis, it is useful to first consider the extent to which the marriage equality story appeared in national newspapers in a post-Charter Canada, and whether coverage correlated with monumental developments. 


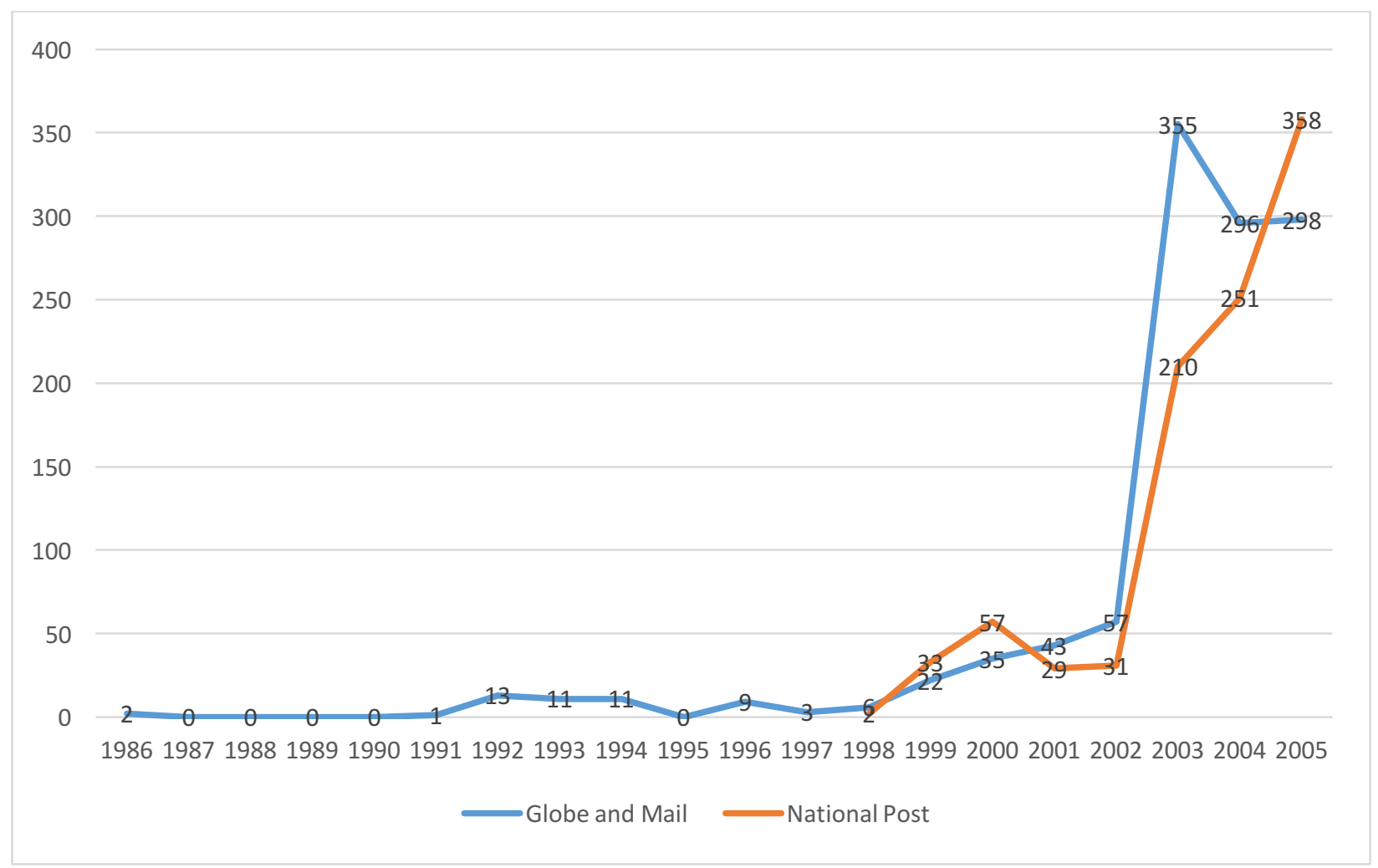

Figure 1 Articles referencing same-sex marriage in Canada

As a result of performing the content analysis, it is possible to quantify the coverage of same-sex marriage in a post-Charter Canada, considering trends in the data as they appear over time. As Figure 1 demonstrates, there most definitely was coverage concerning the legalization of same-sex marriage in a post-Charter Canada. As is evident from the figure above, only two mentions of same-sex marriage appear in the $1980 \mathrm{~s}$ - both are in 1986 . This corresponds to a related major event this year - sexual orientation was added to the Ontario Human Rights Code as a prohibited ground for discrimination that December with the passing of Ontario's Bill 7. The articles are both published prior to the legislation's enactment. The first article on record to mention same-sex marriage, "Executive committee opposes legitimizing homosexual marriage", advances that Toronto City Council's executive committee supported opposition to legitimatizing same-sex marriage; the article also notes that the committee struck down a 
proposal to provide family health benefits to cohabiting same-sex partners. The second article published this decade, "Church rejects theory AIDS is punishment," references a United Church spokesman that said church members were concerned the proposed Bill 7 would permit marriage between two members of the same-sex.

In the 1990s, a court-led charge to attain equal rights gained major momentum, and The Globe and Mail and the nascent National Post took notice. Amongst the developments that took place during this decade include the federal court lifting the country's ban on lesbian and gays serving in the armed forces in 1992; the Supreme Court ruling in Egan v. Canada that sexual orientation is a protected ground and that protection extends to lesbian and gay partnerships in 1995; the Royal Assent of Bill C-33, which added sexual orientation to the Canadian Human Rights Act as a prohibited grounds of discrimination in 1996; and the Supreme Court decreeing in the outcome of $M v . H$ that same-sex couples have the same benefits as opposite sex and common law couples, as well as equal access to benefits from social programs they contribute to in 1999 (however, this ruling did not alter the legal definition of marriage). A total of seventy-six pieces were written for The Globe and Mail during the 1990s; the content of these pieces can be classified as falling under one of three topics: opinion-based commentary about the phenomenon that was the expansion of rights ${ }^{239}$ (including a positive editorial supportive of marriage equality ${ }^{240}$ ); concern politicians and churches had that the passing of policy would lead to marriage ${ }^{241}$; and clarification made by policy-makers that policy would not change the definition

\footnotetext{
${ }^{239}$ See, for instance: Sean Fine, "Courts set seal on gay revolution," The Globe and Mail, November 24, 1992, A1; Douglas Sanders, "Canada's new equal citizens: homosexuals," The Globe and Mail, December 3, 1992, A31; Andrew Coyne, "Two, four, six, eight, where do we discriminate?" The Globe and Mail, May 13, 1996, A14; and Margaret Wente, "Marriage is better than common-law," The Globe and Mail, May 22, 1999, D7.

${ }^{240}$ See, for instance: The Globe and Mail, "The Gay-Bashing Bill," The Globe and Mail, September 12, 1996, A16; The Globe and Mail, "The love that dare not be legally recognized," The Globe and Mail, June 10, 1999, A16. ${ }^{241}$ See, for instance: Anne McIlroy, "Adoption cited for No vote on gay bill: Rock insists Liberal...," The Globe and Mail, May 3, 1996, A4; Anne Mcllroy, "No middle ground in Liberals' battle on gay-rights bill," The Globe and Mail, May 4, 1996, A7; Anne McIlroy, "Gay rights vote expected today: Liberal rejects bids to weaken or...," The
} 
of marriage $\mathrm{e}^{242}$. In contrast, within its first two years of operation in the late 1990 s, the National Post published thirty-five pieces that touched on the issue of same-sex marriage. Again, noticeable trends in subject matter became evident upon analysis: first, prior to, and shortly after the $M . v . H$. verdict, opinion pieces describing concerns about the advancement of gay rights and the significance of defending traditional marriage dominated coverage; in a post-M. v. H. Canada, content exhibited confidence that the definition of marriage will not be changed.

As the timeline showing major developments in the legalization of same-sex marriage in Canada demonstrates (see Appendix A), the push for marriage equality intensifies post $-M$. v. $H$. Beginning in mid-2000, legal cases fighting against the unconstitutionality of the government in refusing to permit same-sex marriages were initiated in Ontario (Halpern v. Canada), British Columbia (Egale Canada Inc. v. Canada; Barbeau v. British Columbia) and Quebec (Hendricks and Leboeuf v. Quebec). That said, coverage is limited, and largely focused on developments within the United States. Major events to receive coverage in 2001 are the same-sex marriages performed by Reverend Brent Hawkes of the Metropolitan Community Church of Toronto using the reading of the banns, as well as the $\mathrm{BC}$ trial court ruling against same-sex marriage. There is a subtle increase in 2002, with the Halpern v. Canada trial court decision made in July 2002, wherein, for the first time in Canada, a court rules in favour of recognizing same-sex marriages under the law; it is determined that it is unconstitutional to prohibit gay couples from marrying, as this violates Charter rights. The province of Ontario was given two years to extend marriage

Globe and Mail, May 9, 1996, A1; Brian Laghi, "Alberta to let court ruling on gay rights stand: Despite opposition...," The Globe and Mail, April 10, 1998, A5; Daniel Leblang, "Pension bill granting same-sex benefits appears likely to pass...," The Globe and Mail, May 22, 1999, A6.

${ }^{242}$ See, for instance: The Globe and Mail, "Changes in family law proposed: Report backs equal rights for marriage and same-sex couples," The Globe and Mail, November 18, 1999, A4; Geoffrey York, "Benefits proposal praised: Rock avoiding controversy over same-sex issue, critics say," The Globe and Mail, May 28, 1994, A6; Richard Mackie and Jane Coutts, "Harris quickly vows conformity with law...," The Globe and Mail, May 21, 1999, A9; Brian Laghi, "Marriage-definition motion," The Globe and Mail, June 8, 1999, A7; and Jill Mahoney, "Alberta gays want laws amended: Protection sought for same-sex couples," The Globe and Mail, November 24, 1999, A3. 
rights to same-sex couples. Quebec follows suit later that year, and British Columbia in 2003. The year 2003 sees a big spike in same-sex marriage coverage, particularly with the Ontario Court of Appeal ruling in favour of same-sex marriage in June of 2003; this is enacted immediately. The federal government swiftly announces that legislation and Supreme Court references are to follow. Over the course of the next year, courts in all provinces except Alberta, Prince Edward Island, Northwest Territories, and Nunavut allow marriages to take place. Finally, in December 2004, the Supreme Court introduces its same-sex marriage bill in the House of Commons. This bill is eventually supported by most of the Liberal party, the Bloc Québécois and the NDP in June 2005, when it passes a final reading and wins the majority vote by a slim margin and receives royal assent to become law the following month. It is at this point that all provinces in the nation have marriage equality.

Based on the quantitative evidence presented, the surge of coverage on marriage equality in Canada corresponded with the seriousness with which courts and legislatures took the matter post $M v . H$. Notably, the issue became especially newsworthy upon the federal government's decision to legalize same-sex marriage across the country in 2003 - a landmark pronouncement that stirred political controversy and tension. Indeed, empirically speaking, an increase in coverage correlated with significant developments in the legitimatization of same-sex marriage in Canada. However, in order to offer a more robust explanation for the heightened newsworthiness of this issue over time, it is necessary to consult those involved with the creation of these stories themselves to get their insights. That said, before doing so, it is imperative to explore the results of the content analysis to identify and breakdown what this content actually consisted of, and how it was framed for readers. 


\section{Content Analysis of Mainstream Press}

I conducted a quantitative content analysis on the issue of legalizing same-sex marriage in Canada as reported in the nation's two national newspapers - The Globe and Mail and the National Post. The rationale for performing an extensive content analysis of these papers is because they circulate throughout the whole country, thus having a large national reach. According to Anders Hansen and David Machin, content analysis viable for "analyzing and mapping key characteristics of large bodies of text, and lends itself well to the systematic charting of long-term changes and trends in media coverage" ${ }^{, 43}$; thus, this methodology is useful to this study, as it has enabled me to track the presence of frames in Canadian national newspapers over a twenty-three year period. As noted, I am specifically concerned with the presence of frames in articles about the legalization of same-sex marriage, because, according to Xigen Li and Xudong Liu, "media coverage of issues of same-sex marriage sets the public agenda, as news coverage of issues of national importance often lead to further discussion on television and the Internet, and affects people's judgment on the issues and decisions in elections." 244

The histories and analyses of news coverage of the legalization of same-sex marriage remains largely focused on the United States; as such, this original content analysis enables one to both determine how this issue was presented to Canadian public, and consider the influence this had on public opinion. US-centric research reveals that while egalitarianism frames were implemented in US media, moralistic frames ${ }^{245}$ were prevalent in shaping the course of the

\footnotetext{
${ }^{243}$ Anders Hansen and David Machin, Media and Communication Research Methods (London, UK: Palgrave Macmillan, 2013), 123.

${ }^{244}$ Xigen Li and Xudong Liu, "Framing and Coverage of Same-Sex Marriage in US Newspapers," The Howard Journal of Communications 21, no. 1 (2010): 72-73.

${ }^{245}$ Issues framed in terms of traditional moral values emphasize that legally granting same-sex marriages conflicts with long-standing social and and religious institutions of marriage and family.
} 
marriage equality debate (Brewer, $2002 \&$ 2003; Tadlock, Gordon, and Popp, 2007; Liebler, Schwartz, and Harper, 2009; Li and Liu, 2010; Pan et al. 2010). Research concerning how this issue has been framed in Canada exists, focusing on courts and legislatures (Matthews 2005), litigants (Smith 2007), and Canadian newspapers (Bannerman 2012). J. Scott Matthews advances that, in the 1990s, the sequence of Supreme Court decisions on the matter of relationship recognition, and the legislative activity that took place as a result, was a strong influence in shaping public opinion; not only did the courts and legislatures frame marriage equality as a matter of equal rights, which is thought to have introduced a new perspective for Canadians to consider when forming their opinion, but the legal recognition of same-sex relationships made such relationships legitimate in the eyes of the public. Miriam Smith compares two 2003 legal cases on same-sex marriage in Ontario (Halpern et al v. Canada) and Massachusetts (Goodridge v. Department of Public Health), arguing that, in both cases, litigants drew on a rights frame; consequently, according to Smith, both cases saw Queer cultural framing become marginalized as legal mobilization presented a heteronormative depiction of same-sex relationships. ${ }^{246}$ Sara Bannerman's study on social cohesion, national identity, and national values as they manifested in Canadian newspaper coverage of the marriage equality concluded that, during the height of the debates (2003-2004), newspapers painted the picture that Canadian values were not threatened by same-sex marriage. Indeed, by June of 2004, this notion that it was consistent with Canadian values of tolerance and accommodation to accept same-sex marriage became the dominant view in newspaper coverage of this matter. With this work, Bannerman is concerned with examining the roles played by newspapers in shaping the construction of Canadian identity. While significant considerations, her work stresses how conceptions of Canadian identity

\footnotetext{
${ }^{246}$ Miriam Smith, "Framing Same-Sex Marriage in Canada and the United States: Goodridge, Halpern and the National Boundaries of Political Discourse," Social \& Legal Studies 16, no. 1 (2007): 22
} 
manifested within the coverage of this issue during a one-year period of time; in contrast, this work investigates over twenty years of reportage to offer an explanation for why marriage equality was treated more fairly by Canadian national newspapers than in the past while considering the effect this had on public opinion on the issue.

In order discover how marriage equality was covered within the pages of Canadian national newspapers - and thus, help fill the gap in the historical knowledge - it is imperative to perform an accurate reading. As such, a non-random, purposive sample was conducted on 1162 articles from The Globe and Mail and 971 articles from the National Post, regardless of what genre the next is and where it was placed in the newspaper; in other words, this analysis examined a census of articles from the two national newspapers. News articles were chosen as the unit of analysis for they are easily accessible content that distributed frames of interest to the proposed study during the appropriate time period. In addition, newspapers perform various roles within a democracy, from alerting partisan groups when their interests are at stake, to helping to balance conflicting interests by having different voices be heard, and to creating a site for reflection. ${ }^{247}$ It must be noted that each paper had different founding dates that impacted the degree to which they could cover the subject matter under investigation; The Globe and Mail was founded in 1844, while the National Post has been in existence since 1998. As a result, The Globe and Mail has had more opportunity to potentially cover the issue, and this needs to be kept in mind. Articles were located via the ProQuest Historical Newspapers: Globe and Mail and Canadian Newsstream databases using the keywords 'same-sex marriage'. The category for content analysis included the following categories: date of publication, newspaper, article type,

${ }^{247}$ C. Edwin Baker, Media, Markets, and Democracy (Cambridge, MA: Cambridge University Press), 129-192. 
and framing type (i.e. equal rights frame, traditional values frame, both, neutral) (see Dissertation Coding Schedule and Coding Protocol in Appendix B). The content analysis was conducted using Excel.

This content analysis will begin by reflecting upon the types of coverage produced, and whether news-format coverage or opinion-format coverage dominated; in so doing, one can have a sense of where the emphasis on their coverage rested: did the paper prioritize rousing debate, or was informing the public of events perceived to relate to their interests more of a concern? ${ }^{248}$ As demonstrated in Figures 2 and 3, more than half of both papers' coverage of same-sex marriage was concentrated in opinion-format areas of the newspaper, while each paper devoted the same amount of coverage to news reporting. Evidently, each paper sought to infuse the public sphere with some perspective on the issue of marriage equality, while also offering informative updates on the state of its development; however, we need to take into account the frames used in these opinion pieces, and whether or not the news reports were written neutrally, in order to get a more accurate sense of the types of content being disseminated to Canadian readers.

\footnotetext{
${ }^{248}$ See, for example: Sara Bannerman, "Same-sex marriage, social cohesion, and Canadian values: A media analysis," Canadian Journal of Communication 36, no. 4 (2012): 610-611.
} 


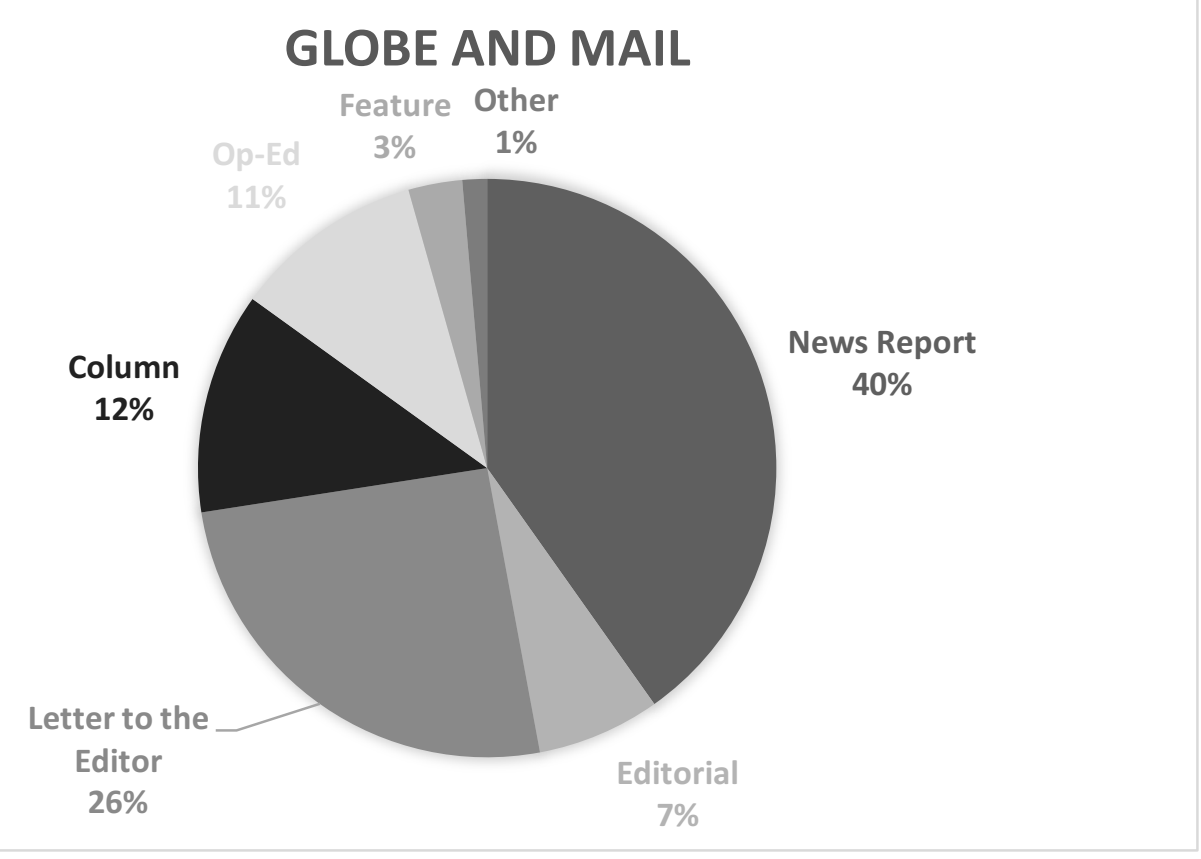

Figure 2 Types of coverage - The Globe and Mail

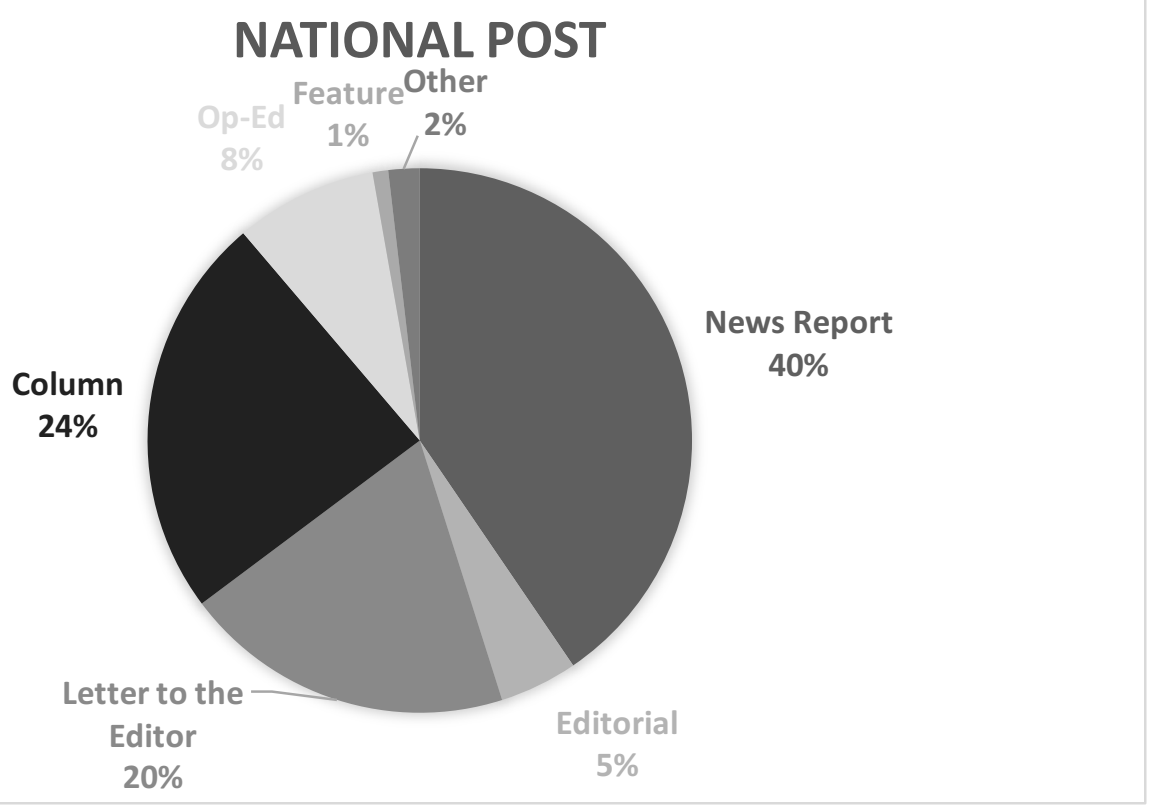

Figure 3 Types of coverage - National Post

Given this, it is crucial to determine the framing type used within each paper; in other words, to what degree did, overall, pieces in these publications incorporate equal rights or tradition values, both frames in the same article, or neutral frames? Table 1 demonstrates that 
more than half of the content of each national newspaper expressed neutrality in their pages, with the National Post edging out The Globe and Mail slightly. That said, the second highest percentage of framing type for The Globe and Mail was equal rights, while the National Post saw this title belonging to traditional values; this reveals that, on the whole, after prioritizing neutrality, each paper gravitated towards a particular frame - either equal rights or traditional values - when it came to the topic of the legalization of same-sex marriage. Certainly, while each paper published articles featuring each frame, they were not featured in equal measure; The Globe and Mail had nearly four times as much equal rights framing overall than traditional values framing, while the National Post had only $7.1 \%$ more coverage of traditional values frames than equal rights frames.

Table 1 Framing type differences between The Globe and Mail and the National Post

Framing Type Used

\begin{tabular}{|c|c|c|}
\hline Equal Rights & & \\
\hline Traditional Values & 30.4 & 10.6 \\
\hline Neutral & 8.4 & 17.7 \\
\hline Both & 52.8 & 65.8 \\
\hline Total & 8.3 & 5.9 \\
\hline
\end{tabular}

The Globe and Mail (\%)
National Post (\%)

We can delve deeper by article type to see where a particular framing type was more predominant by looking at the results in Table 2. News reports were all written neutrally, abiding by known journalistic standards of fairness and balance. The editorial board's point of view on the subject of the legalization of same-sex marriage differed greatly; The Globe and Mail's 
editorials were largely in support of same-sex marriage, while the National Post was more vocal on their support of traditional values; while no single editorial completely offered an equal rights frame, they still mixed in both frames more so than The Globe and Mail. Moreover, opinionbased coverage outside of editorials for The Globe and Mail was heavily leaned towards equal rights framing, while that of the National Post largely incorporated a traditional values frame; however, as indicated above, while each paper skewed towards featuring one frame more than the other, the margin between pieces with traditional value and equal rights frames were significantly less in the National Post. For instance, in The Globe and Mail, equal rights frames in Letters to the Editors is nearly triple the amount of traditional value frames in the same article type, and double for op-eds; for the National Post, there is only a $16.7 \%$ difference between traditional values and equal rights frames in Letters to the Editor, and there is nearly double the amount of traditional value frames in op-eds compared to equal rights frames. Furthermore, in both papers, columns feature much neutrality - this was the case given that columnists tended to comment on the politician navigating with the issue of same-sex marriage, not explicitly comment on or the issue of same-sex marriage itself. That said, The Globe and Mail was more likely than the National Post to feature columns that imbued some type of opinion-based frame (specifically, equal rights frames) almost as often as they expressed neutrality. 
Table 2 Presence of framing type by article type

\begin{tabular}{|c|c|c|}
\hline Framing Type Used & The Globe and Mail (\%) & National Post (\%) \\
\hline \multicolumn{3}{|l|}{ Editorial } \\
\hline Equal Rights & 66.3 & 0 \\
\hline Traditional Values & 0 & 35.6 \\
\hline Both & 15 & 24.4 \\
\hline Neutral & 18.8 & 40 \\
\hline Total & 100 & 100 \\
\hline \multicolumn{3}{|l|}{ Letter to the editor } \\
\hline Equal Rights & 61.5 & 34.6 \\
\hline Traditional Values & 24 & 51.3 \\
\hline Both & 12.5 & 6.8 \\
\hline Neutral & 2 & 7.3 \\
\hline Total & 100 & 100 \\
\hline \multicolumn{3}{|l|}{ Column } \\
\hline Equal Rights & 41 & 8.6 \\
\hline Traditional Values & 0.7 & 12.9 \\
\hline Both & 15.3 & 5.2 \\
\hline Neutral & 43.1 & 73.4 \\
\hline Total & 100 & 100 \\
\hline \multicolumn{3}{|l|}{$O p-E d$} \\
\hline Equal Rights & 38 & 18.3 \\
\hline Traditional Values & 17.7 & 28 \\
\hline Both & 19.4 & 25.6 \\
\hline Neutral & 25 & 28 \\
\hline Total & 100 & 100 \\
\hline \multicolumn{3}{|l|}{ Feature } \\
\hline Equal Rights & 8.6 & 0 \\
\hline Traditional Values & 0 & 0 \\
\hline Both & 5.7 & 0 \\
\hline Neutral & 85.7 & 100 \\
\hline Total & 100 & 100 \\
\hline \multicolumn{3}{|l|}{ Other } \\
\hline Equal Rights & 50 & 11.1 \\
\hline Traditional Values & 18.75 & 22.2 \\
\hline Both & 0 & 0 \\
\hline Neutral & 31.25 & 66.7 \\
\hline Total & 100 & 100 \\
\hline
\end{tabular}


In reflecting on the data collected, it is evident that both national newspapers primarily functioned to instigate debate by dedicating the majority of their coverage of same-sex marriage on opinion-based content. In this context, audiences were presented with equal rights and traditional values frames - albeit to varying degrees - within this opinion-based coverage; The Globe and Mail had predominately equal rights frames, while the National Post had predominantly traditional values frames. Such coverage was complimented by news reports that abided by professional notions of fairness and balance and an absence of biased interference by editors. Cumulatively, we can consider this in relation to the theoretical framework established previously. It was established that the relationship between media and publicness creates an environment hospitable to participation; the circulation of ideas through print, and their subsequent consumption, internalization, and discussion, allows individuals to establish where they position themselves ideologically when it comes to particular issues; they can then base their acts of citizenship around this. Crucially, frames have the potential to impact this; while individuals have agency in arriving at their own conclusions, they often rely on media to provide common frames and reference. As the literature review has discussed, frames may be successful based on factors of mediation (i.e. their repetition, the degree to which there are competing frames, and an individual's own motivations) and moderators (i.e. individual predispositions, knowledge to understand and then be susceptible to frames, presentation, credibility, and availability). Indeed, those who may have had strong views one way or the other could've related to coverage mirroring their values coverage and resisted that which differed from their beliefs; that said, both papers ensured exposure to varying perspectives, thereby possibly influencing a reader to reflect on their stance. In this case, it would appear as though both papers offered fair 
and balanced news reports to give readers the capacity to make accurate decisions about their beliefs on the issues; however, each paper made their ideological positioning on the issue very clear, and while egalitarian and traditional views were featured, they were not evenly placed. This could have certainly affected the competition of frames, thereby giving a preferred frame a better chance of taking root with readers. One cannot ascertain whether public opinion was, in fact, affected by this, but one can argue that the circulation of both neutral updates and differing opinions certainly contributed to their knowledge of the issue, awareness of varying perspectives, shaped any discussions they may have had with others.

Interviews with Journalists: Do Their Memories Align with or Contradict the Content Analysis?

As a means to contextualize revelations from the content analysis and enhance the validity of my findings, I have conducted semi-structured interviews with seven journalists, who wrote stories featured in the non-random, purposive sample between 2001-2005 (four from The Globe and Mail, and three from the National Post). Given the frequency with which they wrote about the legalization of same-sex marriage, they were viewed as valuable sources that could provide first-hand insight into why and how certain frames were decided and implemented by journalists, and how media frames may have implicated understanding of the issue and level of support. The conversation with these journalists were structured under broad topics to assure eventual comparison between the participants (see Interview Guide in Appendix C); an advantage to this interview style was that, while the Interview Guide was followed, it was possible to follow topical trajectories in the conversation that strayed from the guide, so long as they felt appropriate to the goals of the dissertation. What's more, during semi-structured interviews, prompts (i.e. news articles they had written) were utilized to encourage discussion. With all that said, what follows is a condensed compilation of the results of the semi-structured 
interviews, organized by topic, noting the themes that may emerge from these different responses, and how they help explain the results of the content analysis.

\section{Topic 1: What led journalists to write about same-sex marriage}

As previously proven quantitatively, same-sex marriage appeared in the pages of Canadian national newspapers since the late-1980s, peaking at the height of the marriage equality debate in 2003; while it is clear that the issue achieved newsworthiness, in order to better understand why this is the case, it is useful to consult those who wrote these stories to determine what motivated them to write them. The journalists interviewed for this study who wrote for The Globe and Mail revealed that they themselves initiated their coverage of marriage equality as, by the early-2000s, they perceived it to be a major issue in Canada, and thus, required reportage. For instance, as the newspapers' political affairs columnist, John Ibbitson stated he chosen to cover same-sex marriage - however, he suspects he would have been questioned had he not:

Columnists, within limits, are sovereign. And, I say 'within limits', because if I had decided not to write anything at all on same-sex marriage, ever, at some point the comment editor would say, 'John, why are you not writing anything on same-sex marriage?' And, then, I would have to explain for whatever reason I didn't think I should write on same-sex marriage. And, we would've had that conversation, because why do I have a political affairs columnist who won't write on same-sex marriage? That's a legitimate question. ${ }^{249}$

Working out of the Ottawa Bureau, political reporters Gloria Galloway and Campbell Clark covered Canadian politics on Parliament Hill. Galloway mentioned that, while some of her peers in the Ottawa Bureau had beats, they were not strictly beat governed; however, once they started writing about an issue, they would generally continue to do so. That said, she could not remember if this subject matter was assigned to her, or if she asked to cover it. As a Senior

\footnotetext{
${ }^{249}$ John Ibbitson (Staff Writer at Large, The Globe and Mail) in discussion with the author, September $28^{\text {th }}, 2018$.
} 
Political Reporter at the time, Clark wrote about the hot-button political issues of the day; coverage of such issues was split amongst himself and the two other Senior Political Reporters, Shawn McCarthy and Brian Laghi. Clark regularly found himself keeping the public abreast about the activities of the current Prime Minister and his party. When heated debates about legalizing same-sex marriage began to take place in Parliament, this matter became perceived as a highly sensitive political issue; as such, this fell into Clark's journalistic domain, and he covered it for a while. Outside the realm of political reporting, we can turn to Michael Valpy who, in the early 2000s, served as The Globe's Religion Reporter. Echoing the responses of his colleagues, Valpy said he had journalistic freedom to make his own decisions about what to cover but there was an expectation that he would cover current events relevant to his beat. On the topic of same-sex marriage, Valpy reflects, "it was perfectly logical that I would write about the religious opposition to same-sex marriage. I mean, it would have been kind of nonsensical if I hadn't written about it." 250

While working for CanWest, Tibbetts and Naumetz, were frequently received bylines in the National Post; according to Tibbetts:

...it was sort of a hybrid in that the National Post didn't have their own reporter cover justice issues. So they used mine and I guess considered me their reporter in some ways. And they also at the time could take stories exclusively if they wanted to, so some of these stories just appeared in the National Post and the rest of the chain couldn't use them. ${ }^{251}$

Stationed at Parliament Hill, both Tibbetts and Naumetz were able to witness developments in marriage equality take place; however, while each journalist believed the issue was an interesting one, they began reporting on it at different times - perhaps due to Tibbetts' role as a justice reporter, and Naumetz's position as a political reporter. As mentioned at the beginning of this

\footnotetext{
${ }^{250}$ Michael Valpy (retired journalist, Senior Fellow at Massey College) in discussion with the author, April 2019.

${ }^{251}$ Janice Tibbetts (Journalism Instructor, Carleton University) in discussion with the author, October $29^{\text {th }}, 2018$.
} 
chapter, Tibbetts has been focusing on what was happening in the courts for some time before other journalists got on top of the issue. In contrast, Naumetz's coverage of marriage equality picked up in June 2003, following the federal government's announcement that upcoming legislation would legalize same-sex marriage. People he knew in the House of Commons alerted him to the fact that a Special Legislative Committee was being organized to answer the Supreme Court references regarding the constitutionality of legalized same-sex marriage. Naumetz acquired the names of the MPs who would be on the Committee and went to work; his stories were accepted by editors and got carried, which prompted him to continue covering the legislation process. Naumetz believes he was among the first to cover the legalization of samesex marriage in Canada because, thanks to his contacts in Parliament, he was able to acquire information that no one else had to create original pieces of news. Mary Vallis came about writing about same-sex marriage differently; in June 2003, the senior reporter for the National Post was inspired to write about her neighbours - a gay couple - who weren't interested in getting married. Her assumptions about gay couples and marriage were disrupted; as she recalls, she learned from her neighbours that, "[marriage equality is] not just about everyone getting married, it's about wanting that human right, having the option."252 This was an angle to marriage equality that intrigued both her and her editor, and the story was published. ${ }^{253}$ After getting her feet wet in the subject matter, Vallis was moved to the Foreign Affairs desk; there, she continued to take an interest in marriage equality issues in the United States, which demonstrated more polarization than in Canada. The Post's newsroom was one with a culture of pitching, and Vallis continued offering stories about marriage equality; she had been internally

\footnotetext{
${ }^{252}$ Mary Vallis (Journalism Instructor, Centennial College) in discussion with the author, January $18^{\text {th }}, 2019$.

${ }^{253}$ Mary Vallis, "Getting Cold Feet: The Right to Wed is Creating Fresh Tensions for Many Gay Couples," National Post, 28 June 2003, A1.
} 
motivated by her initial story, and seeing how the issue was manifesting in the US, it was hard to ignore discussing it; as Vallis recalls, "At that point you have a bit of a duty to readers to make sure you're reporting on that as well.",254

Ibbitson offered some additional insight that helps explain why the reporters had so much autonomy in their approach to the issue:

If you are a junior reporter, you will defer to the opinions of your editor, and that editor's opinions probably, generally speaking, reflect the editorial board. I mean, there's no conscious adherence to ed. board opinion to newsroom opinion. But, there are shared assumptions, let's put it that way...The older and more senior you get, the more you're able to define your byline. And, if you're a columnist, you should have complete autonomy. ${ }^{255}$

Essentially, the increasing profile of the court cases, the decisive action taken by legislatures to acknowledge relationship rights, and the resulting effect this had on politicians caught the attention of journalists, who believed that these developments could not be ignored. This perspective, in conjunction with the increasing gains in LGBTQ rights in the nation, is suggested to have played a role in making not only the public, but also the national press, aware of the issue's significance; this in turn prompted the national print news media to treat the subject matter with more respect than they had historically. If we recall from the last chapter, LGBTQrelated issues were, for much of the twentieth century, largely ignored or heavily sensationalized by the Canadian mainstream press; indeed, one can postulate that, until the late-1980s, the Canadian LGBTQ community was relegated to The Sphere of Deviance. In contrast, as cases for LGBTQ rights recognition began to be fought in the courts and taken seriously by legislatures, suddenly, the matter gravitated to The Sphere of Legitimate Controversy, wherein these developments were not only acknowledged in print, but treated within journalistic conventions of

\footnotetext{
${ }^{254}$ Mary Vallis (Journalism Instructor, Centennial College) in discussion with the author, January $18^{\text {th }}, 2019$.

${ }^{255}$ John Ibbitson (Staff Writer at Large, The Globe and Mail) in discussion with the author, September $28^{\text {th }}, 2018$.
} 
fairness and balance - the results of the content analysis and the interviews validate this. That said, it is necessary to now consider how the subject matter itself was treated.

\section{Topic 2: Frames used to discuss the legalization of same-sex marriage in Canada}

Taken as a whole, the responses suggest that the participants believe producing completely objective journalism was, and remains to be, not plausible; however, all of them ascertained that, when it came to news reporting, they aimed to be as fair as possible. As Galloway reflects, "the thing that you try to do is to present the most fair, balanced, straight up story without your own sort of perspective filtering and becoming interwoven into what you're writing. ${ }^{256}$ They saw it as their obligation to their readers to ensure fairness, and this was achieved by offering many perspectives throughout their representation of the issue, as it was their obligation to readers to do so; in other words, there was a self-awareness on the part of each reporter to acknowledge the existence of their biases and work to maintain fairness. For instance, Vallis stated, "when we understand where we come at an issue from or what we feel is important about it, we have an obligation to our readers to be fair, right? And that doesn't mean you have to call up a Right Wing tyrant who is full of hate for every story that you write, but making sure that you reach out to the various stakeholders or perspective."257 Tibbetts echoes this when she states, "So I think that fairness to me is just you do want to represent, it makes sense to always look for opposing voices on things, but not gratuitous opposing voices on things just to have $50 \%$ nah and yeah. ${ }^{, 258}$ Clark mentioned that neutrality was easy to achieve when all one had to do was quote different views; he states:

It's easier [to be neutral] for me than it is for most. It wasn't that hard in the context of a political debate at those times. Because if you quote people with three different views,

\footnotetext{
${ }^{256}$ Gloria Galloway (Former Staff Reporter, Parliamentary Reporter, The Globe and Mail) in discussion with the author, October $2^{\text {nd }}, 2018$.

${ }^{257}$ Mary Vallis (Journalism Instructor, Centennial College) in discussion with the author, January $18^{\text {th }}, 2019$.

${ }^{258}$ Janice Tibbetts (Journalism Instructor, Carleton University) in discussion with the author, October $29^{\text {th }}, 2018$.
} 
you are reflecting three different views. And really the main story is usually about what the government will or will not do. So it wasn't that hard to stay fairly neutral in those stories 'cause you don't really have to provide your opinion. ${ }^{259}$

Interestingly, Naumetz stressed that not only was it ethically important to write fairly, but necessary to gain trust of sources; after establishing trust with sources, they would continue to tip him off to valuable information. From Ibbiton's experience as a columnist, he, as well as The Globe and Mail, were in favour of same-sex marriage from the get-go, which influenced his framing and discussion of the issue. That said, he advances that this freedom to opine honestly without influence from editors can be attributed to the hiring choices; Ibbtison states, "In your hiring choices, in your assumptions, you've picked like-minded folks, absolutely. The National Post has a different way of viewing the world from The Globe and Mail, and The National Post hired Andrew Coyne and The Globe and Mail hired me. That's not some kind of directed conspiracy, that's just like hiring like.",260

Evidentially, those journalists who wrote news stories about marriage equality operated in accordance to current occupational ideology - that is, they reported ethically, consistently striving for fairness and balance. The lone columnist interviewed was free to infuse their opinion into their writing - an opinion that matched that of their employer. As such, audiences were being offered both informative news stories and opinion pieces that disseminated the viewpoints of pundits, thus not only exposing them to varying perspectives, but giving them accurate information to assess them and form their own opinion. With this in mind, it is worth exploring what method each journalist took to writing about the subject - if the issue was treated within expected journalistic conventions, what approach to the topic might journalists have decided to take, and why?

\footnotetext{
${ }^{259}$ Campbell Clark (Chief Political Writer, The Globe and Mail), in discussion with the author, October $23^{\text {rd }}, 2018$.

${ }^{260}$ John Ibbitson (Staff Writer at Large, The Globe and Mail) in discussion with the author, September $28^{\text {th }}, 2018$.
} 


\section{Topic 3: The creation of stories regarding the legalization of same-sex marriage}

When it came to the creation of stories about marriage-equality in Canada, each journalist described different experiences that, upon reflection, revealed some commonalities amongst the interview participants. In covering the religion beat, Valpy wanted to write about same-sex marriage in a way that explained how the opposition was taking shape; in other words, he wanted to make clear how impactful the opposition/Christian influence was on the debate. He did not have any difficulty finding people to speak with on either side; Valpy mentions religious people on both sides of the issue wanted their narratives reported in The Globe and Mail, because it had a big influence in the country. He did his utmost to keep his own views out of the articles, but he admitted they might have crept in at times.

Clark's approach to covering marriage equality was to focus on how this was a political controversy that divided the Liberal party. This meant he was discussing the political aspect of the issue, not the legal aspect; the courts made these decisions, and then the political parties fretted. As such, his work asked questions such as: will legalized same-sex marriage pass? Will it have support? Will parties fall apart? In terms of constructing these stories, there was not much need to reach out to activist groups, because they were represented in Parliament. Many of these stories were politicians trying to respond to what the court was telling them were basic human rights; as such, sources at the time were mostly court decisions and members of Parliament, and no major players. The way these stories were written is slightly different than how they would be written now, because there is far more of what journalists call "he said, she said". Today they would probably put in less voices on either side because in many cases it would be less about the debate and more about what is going to happen. 
Galloway stated that, in presenting her stories, she tried to filter out any sort of biases and leadings that she might have; she tried to present the most fair, balanced, and straight up story without her own filtering and becoming interwoven into what her writing. The construction of stories, for her, meant going out, asking people about whatever issue it is that she's reporting about, and portraying their perspective as honestly and openly as she could.

When writing columns, Ibbitson noted he had choice - indeed, he did choose to write about same-sex marriage, however, there would be some push-back if the content was completely one-sided or outrageous; there was large latitude within the bounds of what the paper considered inappropriate. His vocal support for same-sex marriage had to do with it being consistent with his Libertarian position.

Naumetz had been covering Parliament since 1981, beginning with his time with the Canadian Press; throughout the years, he'd developed contacts in the places that count, like those in the West Block offices, "because they're the people who, once a PM or opposition leader and their support staff decide on who they want in committees then that office... they're the ones who sort of do the mechanics of linking these people up and organizing them." ${ }^{261}$ When it came to covering same-sex marriage in Canada, the best source of information in Parliament were MPs and senators. Through the years, he learned they do like to converse like they're back benchers; however, he noted they were more open back then. There were also contacts within the West Block offices that were acquired through association, and he owes his early leads to marriage equality stories to these contacts.

When it came to covering marriage equality, Tibbetts' knew this was an important issue, and she intended to cover it tip to tail. When she began following the issue, she did not face

${ }^{261}$ Tim Naumetz, (Politics Report, iPolitics) in discussion with the author, November $16^{\text {th }}, 2018$. 
much competition, as it was not very crowded - something Tibbetts enjoyed. As a result, she was able to cultivate sources, including the Justice Department Official, the Justice Ministers Office, MPs, and later the Prime Minister's office, as well as lawyers, members of Egale and their supporters, who she could probe more deeply than she could nowadays; not only would these sources would tip her off to valuable information, but because of her visibility in covering this issue, people would approach her. By the time the issue reached the Special Legislative Committee hearing in Parliament, etc., she had gone to all those hearings, and build up quite the base of people who would take to her about it and she was at all the hearings. According to Tibbetts, in the early 2000s, it was not a lonely beat per se, but it was a beat many were not covering. This changed in 2003, when the Liberals hopped on board, and suddenly, the issue became extensively covered. That said, when it came to developing stories, she spoke with those behind the scenes to uncover what was happening and what was not being covered; as a beats reporter, she was not necessarily assigned topics, and as such, she would have to be enterprising. In taking on the marriage equality beat, Vallis saw it as her mission "to explain and to shed light on the fascinating reasons these people make their decisions and live their lives in different ways. ${ }^{262}$ Indeed, it genuine curiosity about the issue was what drove her to cover the issue in the first place; she states, "I think that's a natural place of curiosity for a journalist, and I'm not personally invested in the issue beyond, I'm not gay, I have no emotional tie to the issue other than watching people I knew grappling with it which is where that first story came from which I thought was interesting. ${ }^{, 263}$ She had no issue speaking to American sources - partly because she believes they were more open to speaking - and she had developed relationships with a few of the big 'think tanks" and organizations that were frequently offering insights about

\footnotetext{
${ }^{262}$ Mary Vallis (Journalism Instructor, Centennial College) in discussion with the author, January $18^{\text {th }}, 2019$. ${ }^{263}$ Ibid.
} 
the issue. She would also mine local coverage and reach out to those who have already been publicly speaking about marriage equality.

All journalists revealed they had no issues with editors when it came to the writing of stories on the topic of the legalization of same-sex marriage in Canada; while clarification about content might have been sought out by editors, there were never any attempts made to control the direction of the reporting, or to infuse certain perspectives into the journalism being produced. Ibbiton revealed that the only time an editor would be upset with them would be if they'd not covered something relevant within the realm of political affairs - that is, their assigned beat; neglecting to cover same-sex marriage in the nation would've been one such case, were it to occur.

Even while operating in accordance to accepted journalistic standards and expectations of newsworthiness, interviewees were given given freedom to conduct reportage per their role and their beat with scarce interference from their employers. As such, reporters covered marriage equality uniquely, as determined by their choice in angle and the access they had to particular sources. The result was informative pieces that were free of editorial biases (with the exception of opinion-based columns, naturally). That said, while it is been argued above how, collectively, these stories could affect public opinion, it is useful to consider whether journalists perceive their work as impacting opinion; this can give us a clearer picture of the extent to which their pieces may have affected public opinion concerning the legalization of same-sex marriage.

\section{Topic 4: Does reporting affect public opinion}

Regarding the journalists' perspectives on the degree to which their reporting might have impacted public opinion, the general consensus was that it was difficult to ascertain what impact their reporting might have had on Canadians' opinions about legalizing same-sex marriage in the 
nation; however, there was an awareness that media does have an influence in society, serving an informative role - 'holding a mirror up to society' as Galloway offers:

I'm sure the media has had a lot to do with it, but it's just the pace of societal change has just been so dramatic. The media does, I think, both a catch up job of it and also a propelling forward of it. In some ways we're a mirror on society and in some ways we do spur change I'm sure. Anyway, I mean it's only because we broaden people's, not views, but we broaden people to a whole different array of sort of ideas that they may not have ever encountered if you hadn't, if you'd been living in your own little pod, in your own little community, in your own little world. ${ }^{264}$

Addressing this specifically to the case under investigation, reporters posited that, seeing as the

Canadian LGBTQ community was gaining incremental legislative wins since the 1990s, and that

the matter of marriage equality was framed in the courts as one concerning human rights, the

public was being exposed to the judiciary's frame via news reporting; as Tibbetts suggests:

So I think that maybe...extensive news coverage may have helped...because a lot of the news coverage was based around "This is what courts were saying...," so it just was through the lens of this is fairness... it was a legal story for a long time. And there weren't very many losses. They were all wins toward the LGBTQ community, pretty much. So...I think it became, I guess, more palatable that way because they were incremental wins. That society had time to get used to the idea. And even by 2005, by the time legislation was being debated in Parliament, and it was passed, like I said, to me it was over. It was, society was already there for the most part. ${ }^{265}$

Similarly, Clark offered that it was not only the public who might've been affected by the judiciary's framing of the issue, but journalists themselves:

You have to remember that the way the story developed had an impact on the people writing about these things, too. The sort of general middle ground of society moved along. The biggest impact in my view was courts saying, "This is a Charter question on basic human right," which forced people to think about it in a different context and it was then a question of 'why not' rather than 'why'. And so that commentary came to be reflected [in news stories through the content reported]. ${ }^{266}$

\footnotetext{
${ }^{264}$ Gloria Galloway (Former Staff Reporter, Parliamentary Reporter. The Globe and Mail) in discussion with the author, October $2^{\text {nd }}, 2018$.

${ }^{265}$ Janice Tibbetts (Journalism Instructor, Carleton University) in discussion with the author, October $29^{\text {th }}, 2018$.

${ }^{266}$ Campbell Clark (Chief Political Writer, The Globe and Mail), in discussion with the author, October $23^{\text {rd }}, 2018$
} 
What's more, Ibbitson commented on the gatekeeping capacities of newspapers in a pre-social media era, and how this would have influenced the shape of the debate: "We're talking 2005, so you had the Internet. You had blogs, but you didn't have Facebook or Twitter, so the media exercised a very powerful gatekeeping function. The Globe and Mail and The Toronto Star and the National Post, the $C B C$, and CTV Global News would have been an important factor in contributing to the debate, both pro and con." ${ }^{267}$ What's more, the dissemination of select public opinion via the Letters to the Editor would hold more weight at this time as well, “...in those days the Letters Pages mattered. I mean, The Globe and Mail's Letters to the Editor were really powerful and important. Not anymore, I don't think, because of social media. But, in those days, I mean, I read them. People read them religiously. So, they were part of the debate. That gatekeeper function has changed incredibly, but it was still exercised." 268

Indeed, journalists viewed their role as one that involved informing the public about pressing societal matters; in this case, marriage equality's eventual newsworthiness enabled it to be a matter that was viewed necessary to keep the public up-to-date about. In the process of offering both accurate reportage and rousing debate through opinion pieces, it can be suggested that both readers and journalists alike could come to grasp the urgency and importance of this issue and the inevitability of marriage equality. Of course, it must be pointed out that this could not be a possibility were the issue not considered newsworthy in the first place.

\section{$\underline{\text { Conclusion }}$}

This chapter has argued that, based on the evidence of the data collection, the seriousness with which the legislatures began to take issues of relationship recognition and rights by 2003 , and the political tensions these outcomes stirred, prompted for the legalization of same-sex

\footnotetext{
${ }^{267}$ John Ibbitson (Staff Writer at Large, The Globe and Mail) in discussion with the author, September $28^{\text {th }}, 2018$. ${ }^{268}$ Ibid.
} 
marriage in Canada to become newsworthy to mainstream journalists; in conjunction with this, while reporters of Canadian national newspapers treated the issue fairly, and opinion pieces disseminated varying degrees of equal rights and traditional framing, the framing of the issue in the courts was disseminated simply by being featured in news reporting, thus having the potential to not only reach and affect the public, but also the reporters themselves. While this helps to explain how the mainstream viewed and presented the issue, how was the marriage equality issue taken up by members of the LGBTQ community? Was this an issue in which the community was unified? If not, what were their critiques? How did Canadian gay presses reflect and contribute to discussions about marriage equality within the LGBTQ community? Did mainstream coverage accurately reflect these perspectives? A discussion of the gay liberation movement and gay activism in Canada will offer context, while evidence from interviews with Canadian gay activists will offer further insight. Taken together, this chapter will not only shed light on how the Canadian LGBTQ community viewed the legalization of same-sex marriage and sought to communicate about it, but, as we will see, it also offers an additional explanation for why the issue of marriage equality became newsworthy. 


\section{Chapter 4: Writing for the Community}

\section{$\underline{\text { Introduction }}$}

As the previous chapter has demonstrated, Canadian national newspapers disseminated significant coverage on legalization of same-sex marriage in a post-Charter Canada (particularly in the early 2000s), thus filling the mainstream with news reports that abided by known journalistic conventions, and opinion-based pieces that shared equal rights and traditional values frames in varying degrees. Consequentially, Canadian audiences were presented with both accurate accounts of the developments of marriage equality and different viewpoints on the matter with which they could base their opinion and utilize in their interpersonal discussions. However, did mainstream coverage about the legalization of same-sex marriage in Canada selected and designed to be of significance to targeted mainstream audiences - accurately reflect the perspectives of the Canadian LGBTQ community? The purpose of this chapter is to address this question, which allows us to not only consider if The Globe and Mail and the National Post were precise in their reporting of the issue, but to become aware of the various viewpoints about marriage equality that existed within the LGBTQ community at this time. In order to tackle this query, it is imperative that we briefly unpack the history of the gay liberation movement in the nation so that we can discern how marriage equality fit in with activist aims, and why certain approaches towards this issue came to carry more weight in the realm of Canadian gay activism than others. Through this, rationales for and against same-sex marriage by community members will be revealed and unpacked. Next, based on their experiences as Canadian gay activists in the late-twentieth century and early twenty-first century, five interviewees share their perspective on why they believe Canadian mainstream print publications framed marriage equality in the manner that they did, and speak to their participation in interviews with national media on the 
issue; the responses allow us to more precisely evaluate why journalists took up the issue they way they did, and how accurately the voices of the queer community were presented. We can then look to the Canadian gay presses - which, as a form of alternative media, sought to provide a range of ideas and opinions that serve the community that might otherwise be poorly represented in major commercial media outlets - to learn about how community discussions about marriage equality were reflected within their pages; such an exploration will reveal the degree to which their content was similar to the national newspapers. Through this, an argument can be made as to why marriage equality became newsworthy for Canadian mainstream audiences.

Based on the evidence presented, this chapter argues that Canadian national newspapers were somewhat accurate in sharing the LGBTQ community's perspectives on marriage equality. Notably, they failed to report on the conflicting attitudes towards marriage equality that existed within it. The dominance of the assimilationist perspective amongst the most vocal and visible activists meant these were the voices included in coverage of court cases and legislation, and thus were more likely to be featured in mainstream reportage on the topic. In addition, the mainstream media is thought to have been more receptive to treating this issue seriously because the bid to assimilate into a heteronormative institution was nonthreatening. Activists perceived as being able to provide practical insights into matters were contacted by journalists in an effort to gain insights that allowed them to provide a more balanced story about an event; that said, when it came to discussions of marriage equality, those notorious for radical beliefs that did not fit neatly into a 'traditional' or 'egalitarian' frame were omitted from news stories. As a result, the mainstream press was unable to truly capture the dissent that existed within the community, resulting in the projection of the image of a community that were all rallying for marriage 
equality. That said, interviewees commended print journalists for exhibiting professionalism, with the exception of radio talk show hosts who tended to place interviewees in uncomfortable confrontations with ideological opponents. In contrast, major Canadian gay publication Xtra! operated at the height of discussions surrounding marriage equality, and sought to inform readers about current events and offer advice on how to respond; while editorials did not spell out Xtra!'s position on marriage equality, the editorial team made an effort to showcase both assimilationist and liberationist perspectives offered by contributors.

\section{A History of Canadian Queer Activism}

Through a condensed overview of the history of gay liberation in Canada, we may become aware of the organization and ideology that propelled societal change; in the course of this, we can identify where marriage equality fit in with activists' agenda. Indeed, it is not my intention here to offer a comprehensive history of queer activism in the nation, but, to instead, highlight the motivations and trajectories that accompanied the gay liberation movement. That said, it is necessary to stress that queer activism has been the subject of much writing. For instance, the work of Gary Kinsman (1996), Tom Warner (2010), and Tim McCaskell (2016) stand out as extensive explorations of the history queer activism in Canada, while Peter Knegt (2011) and Miriam Smith (2012) offer more distilled accounts of major developments. Edited collections exist that offer more focused explorations on critical concepts; for example, Manon Tremblay (2015) compiles a series of works that comment on how different levels of the Canadian government have tried to control and suppress queer activism, and, in contrast, how activists have utilized policy to make gains, while Patrizia Gentile et al. (2017) focus on sharing neglected histories of Canadian sex and gender activism. Responses by Canadian activists to the HIV/AIDS crisis is observed in the works of Michael P. Brown (1997), Ann Silversides (2003), 
and Richard Fung and Tim McCaskell (2012). Studies speaking specifically to the impact of the Charter on Canadian gay activism are presented by Kathleen Lahey (1999), Miriam Smith (1999), and Bruce MacDougall (2000). On this note, through comparative analysis, the works of both David Rayside (2008) and Miriam Smith (2008) illustrate LGBTQ activism in Canada and the United States shared similar ideologies, yet manifested differently due to their distinct political institutions, thereby implicated mobilization. Sources that offer firsthand testimony and direct evidence of efforts to mobilize LGBTQ Canadians include the edited anthology Flaunting It!: A Decade of Gay Journalism From The Body Politic (1982), which assembles key pieces published in The Body Politic, and archival collections at The ArQuives (formally the Canadian Lesbian and Gay Archives), the British Columbia Gay and Lesbian Archives, and the Quebec Gay Archives. Finally, Donald W. McLeod's Lesbian and Gay Liberation in Canada: A Selected Annotated Chronology, 1964-1975 (1996) and Lesbian and Gay Liberation in Canada: A Selected Annotated Chronology, 1976-1981 (2017) present a streamlined chronology of major dates and events in the liberation movement, as well as lists of Canadian LGBTQ organizations, periodicals, and bars and clubs. 


\section{Gay Liberation}

In the wake of post-Second World War panic and the regulation of sexuality ${ }^{269}$, the initial formation of lesbian and gay cultures in in 1950 s and $1960 \mathrm{~s}^{270}$, and early homophile organizing in the mid-1960s ${ }^{271}$, the gay liberation movement emerged in Canada in 1969, sparking a new era for Canadians to begin constructing a politicized sexual identity. ${ }^{272}$ Although Canada's Criminal Code was revised in 1969 to partially decriminalize homosexual activities - relegating them to the private realm - there remained room for both police and courts to oppress ${ }^{273}$; charged by conservative social values, police raids on queer public spaces continued to be conducted, ${ }^{274}$ while courts expressed a desire to 'control the spread' of homosexuality. ${ }^{275}$ In conjunction with this, while legislated human rights appeared in Canada after the Second World War - instigated by Canada becoming a signatory of the United Nationals International Declaration of Human Rights in $1948^{276}$ - constitutional human rights would not be instituted until 1982; crucially,

\footnotetext{
${ }^{269}$ For comprehensive histories of post-Second World War panic and the regulation of sexuality in Canada, see: Gary Kinsman and Patrizia Gentile, The Canadian War on Homosexuals: National Security as Sexual Regulation (Vancouver, British Columbia: UBC Press, 2010); Mary Louise Adams, The Trouble With Normal: Postwar Youth and the Making of Heterosexuality (Toronto: University of Toronto Press, 1997); Mona Gleason, "Psychology and the Construction of the 'Normal' Family in Postwar Canada, 1945-1960," The Canadian Historical Review 78, no. 3 (1997): 442-477; Cameron Duder, Awfully Devoted Women: Lesbian Lives in Canada, 1900-65 (Vancouver, British Columbia: UBC Press, 2010); Elise Chenier, Strangers in Our Midst: Sexual Deviance in Postwar Ontario (Toronto: University of Toronto Press, 2008).

${ }^{270}$ See, for instance: Tom Warner, Never Going Back: A History of Queer Activism in Canada (Toronto: University of Toronto Press, 2002); Gary Kinsman, The Regulation of Desire: Homo and Hetero Sexualities (Montreal: Black Rose Books, 1996): 224-225; Manon Tremblay, "Introduction," in Queer Mobilizations: Social Movement Activism and Canadian Public Policy, ed. Manon Tremblay, (Vancouver: UBC Press, 2016), 13-14; John Grube, "Natives and Settlers: An Ethnographic Note on Early Interaction of Older Homosexual Men With Younger Gay Liberationists," Journal of Homosexuality 20, no. 3-4 (1991): 119-135.

${ }^{271}$ See, for instance: Tom Warner, Never Going Back: A History of Queer Activism in Canada (Toronto: University of Toronto Press, 2002); Gary Kinsman, The Regulation of Desire: Homo and Hetero Sexualities (Montreal: Black Rose Books, 1996): 224-225.

${ }^{272}$ Miriam Smith, Lesbian and Gay Rights in Canada: Social Movements and Equality-Seeking, 1971-1995 (Toronto: University of Toronto Press, 1999): 8-9.

${ }^{273}$ Kinsman and Gentile, 221-335.

${ }^{274}$ Knegt, 52.

${ }^{275}$ Bruce MacDougall, Queer Judgments: Homosexuality, Expression and the Courts in Canada (Toronto: University of Toronto Press, 2000), 87.

${ }^{276}$ Kathleen Lahey, Are We 'Persons' Yet: Law and Sexuality in Canada (Toronto, University of Toronto Press, 1999): 100-126.
} 
despite advancements towards implementing human rights protections in the 1950s and 1960s (including Ontario's consolidation of antidiscrimination laws into a comprehensive Human Rights Code and commission in 1962, from which other provinces followed suit) protections of LGBTQ community members was absent from such legislation. ${ }^{277}$ Such social and legal conditions made the environment ripe for reform. Indeed, the acquisition of human and civil rights were perceived as easily understandable issue with which to organize and set an agenda around; it helped that these goals were thought to be an attractive pursuit for both assimilationists (those who viewed obtaining legal rights as the primary objective of their activist efforts) and liberationists (those who viewed human rights campaigns as a means to an end). ${ }^{278}$ Given the spread of liberationist groups across Canada, it was possible to lobby about human rights codes at federal, provincial, and municipal levels of government. Furthermore, despite the geographic distance between groups, several national initiatives came into being as well, including the first lesbian and gay rights demonstration on Parliament Hill in 1971 to present demands required for equality for Canadian queer people, the creation of The Body Politic, the national's gay liberation journal, later that year, the beginning of Pride events across the nation, beginning in Toronto in 1972, and two National Gay Election Coalitions in 1972 and 1974. That said, despite efforts to place pressure on governments, by 1982, only Quebec and three Ontario cities (Toronto, Ottawa, and Windsor) had passed laws banning discrimination on the basis of sexual orientation; however, at this time, not only was a new level of consciousness achieved amongst community members, but a foundation was laid for activists to build upon in future years.

By the early-1980s, a re-evaluation of activist aims took place; as Manon Tremblay notes, "the HIV/AIDS crisis and the Charter were to dictate the agenda of Canadian LGBTQ

\footnotetext{
${ }^{277}$ Tom Warner, 30.

${ }^{278}$ Tom Warner, 70.
} 
activists for decades to come, whether the aim was to attain protection against discrimination, to gain recognition for same-sex unions and their families, to obtain health care services adapted to the needs of LGBTQ people, or to provide information to young people about sexuality.",279 In light of this, two distinct pathways emerge by the mid-1980s that come to transform how activism played out in the following decade and the new millennium - one that is rights-oriented, and the other that seeks the continuation of liberation tactics. Gary Kinsman notes we can understand the activism that moves forward "within a broader context of sexual and social struggles; one characterized by struggles over the Charter of Rights and Freedoms and equality rights on the one hand, and intensified sexual policing and the continuing denial of our actual sexualities and relationships on the other. ${ }^{, 280}$ Operating concurrently to HIV/AIDS activism, the rights-oriented track ended up winning out; reasons for this include the liberationists facing emotional and financial exhaustion by the $1980 \mathrm{~s},{ }^{281}$ as well as the assumption of leadership by white, middle-class activists not imbued with a liberationist perspective. ${ }^{282}$ That said, as Miriam Smith notes, the existence of the Charter - particularly Section 15, which guaranteed equality rights - was closely scrutinized by activists, who, since its inception in 1982, saw the legislation as a tool to guarantee the equality of all community members. ${ }^{283}$ That said, when the Charter did not explicitly include sexual orientation - even after representations had been made to the federal government to advocate for its inclusion - activists grew concerned; as Tremblay says, the subsequent lack of protection, "fully endorsed by the state and as a consequence of its homophobia and heterosexism, combined with the many kinds of discrimination experienced by

\footnotetext{
${ }^{279}$ Tremblay, 18-19.

${ }^{280}$ Kinsman, 375.

${ }^{281}$ Knegt, 12.

${ }^{282}$ Tom Warner, 2002, 192.

${ }^{283}$ Smith, 1999, 101-106.
} 
gays and lesbians led the movement to demand that the state focus on the area of rights, notably with regard to recognition of same-sex relationships. ${ }^{284}$ Indeed, the presence and legitimacy of the Charter heightened the possibility that efforts to challenge existing legislation could actually be accomplished; whereas activists in the 1970s anticipated that any efforts to do so would would fail, but at least succeed in building visibility (such as Vogel and North's case), suddenly, the existence of the Charter made instigating change a real possibility. ${ }^{285}$ Egale, Canada's sole national queer lobby group, capitalized upon this opportunity, serving as a lobbying group for equal rights. Founded in 1986, Egale lobbied MPs and governments with a main goal of taking a role in Charter cases and litigation involving sexual orientation. ${ }^{286}$ Such reformist activism resulted in rights gains, including: repealing the ban on gay and lesbian Canadians serving in the Canadian Armed forces (1992); the federal government ruling to amend the Canadian Human Rights Acts to add sexual orientation to the list of prohibited grounds (1992); the Supreme Court ruling that sexual orientation is analogous to grounds for discrimination (Egan and Nesbitt $v$ Canada, 1995); sexual orientation being read into Alberta's human rights laws (Vriend v. Alberta, 1998), and the Supreme Court of Canada agreeing that family law must include samesex couples $(M v . H, 1999)$.

By the early 2000s, the battle for marriage equality came to monopolize the Canadian LGBTQ activist agenda. Suddenly, as Knegt notes, the movement became associated with reform rather than liberationist ideologies, being fought more in the courtrooms than on the streets, "where a sense of community could be negotiated." ${ }^{, 28}$ Knegt continues by stating, "the

\footnotetext{
${ }^{284}$ Tremblay, 18.

${ }^{285}$ Smith, 109-110.

${ }^{286}$ Miriam Smith, 1999, 77-101.

${ }^{287}$ Knegt, 42.
} 
politics of these legal cases became more defined by the individuals and their lawyers, whereas

legal decisions before this usually occurred in the context of social struggles and organizing."288

But, as will be seen later, this decision wasn't unanimously accepted by community members.

That said, what emerged instead was a predominance of rights-based activism and rights talk, which advanced a drive to pursue issues related to citizenship and equality rather than toppling oppression. As Miriam Smith writes:

Rights talk equates legal change with social and change and neglects the deployment of rights as political resources. While the gay liberation movement focused on challenging social codes and viewed demands on the state as a means of mounting this challenge equality-seeking in the eighties and nineties [was] increasingly focused on challenging state police as an end in itself... rights talk is unreflexive about the nature of activism; as a meaning frame for social movement activism, it privileges legal victory over societallydirected challenges. ${ }^{289}$

\section{History of the Gay Press in Canada}

The early 1960s saw not only the early foundations for what would eventually become gay liberation movement laid in Canada, but also the beginning of a gay press; for the Canadian queer community to create and control its own media was significant, for it not only enabled the building of community and the organization of activists, but served as a platform to counter societal ideologies that permeated the mainstream media. Gay presses served an invaluable role in disseminating community voices and mobilizing community members amidst a mainstream environment. As Donald McLeod's annotated chronologies of lesbian and gay liberation in Canada reveal, efforts to operate gay presses began in the year 1964, with three publications being founded that year: tabloid magazine Gay, the newsletter for the Vancouver-based homophile group ask ASK Newsletter, and homophile magazine Two. The lifespan of these publications were short, ranging anywhere between one to four years; causes of collapse

\footnotetext{
${ }^{288}$ Ibid.

${ }^{289}$ Smith, 1999, 22.
} 
included difficulty in attracting and maintaining an audience (i.e. Gay) ${ }^{290}$, the folding of the sponsoring organization (i.e. Ask Newsletter) ${ }^{291}$, or police raids (i.e. Two) ${ }^{292}$. McLeod observes that the death of Two magazine in 1966 had ripple effects on the existence of gay publications in the nation. In Toronto, there would be a slump in non-physique presses until 1970, with the UTHA Newsletter (later called Gayokay, and lasted two years), and Phalia, the club newsletter of Spearhead Toronto (June 1970-May 1973) eventually gaining some traction for a time; for the rest of Canada, after the demise of $A S K$ Newsletter, no paper could survive a few issues until the 1970 s. $^{293}$

Indeed, in the wake of Two, publications that emerged included Derek G. Travis' Exclusive Male in 1972 in Toronto, a general interest magazine for gay men, which lasted ten issues $^{294}$, and Gay Tide, a Vancouver-based publication ran by liberation group Gay Alliance Towards Equality, which ran from $1973-1980 .{ }^{295}$ Publications existed that also catered to lesbians. The Other Woman was established in 1972 in Toronto and ran for five years, contained material written from a lesbian-feminist viewpoint; it was published in cooperation with feminist newspapers Bellyful and Velvet Fist. ${ }^{296}$ Long Time Coming would be established in Montreal in 1973 as the first lesbian journal published in Canada, which featured news, poetry, opinion pieces, book reviews, advertisements, and listings; it dissipated after three years. ${ }^{297}$ While several periodicals created by and for the Canadian queer community continued to circulate well

\footnotetext{
${ }^{290}$ Donald W. McLeod, A Brief History Of GAY, Canada's First Gay Tabloid, 1964-1966 (Toronto: Homewood Books, 2003), 75.

${ }^{291}$ McLeod, Lesbian and Gay Liberation in Canada: a Selected Annotated Chronology, 1964-1975, 7.

${ }^{292}$ Kinsman, 249.

${ }^{293}$ McLeod, A Brief History Of GAY, Canada's First Gay Tabloid, 1964-1966, 76.

${ }^{294}$ John Kennedy, "Pride in Our Press: Toronto's History of Gay Publications," fab, June 10-23, $1999,24$.

${ }^{295}$ McLeod, Lesbian and Gay Liberation in Canada: a Selected Annotated Chronology, 1964-1975, 69.

${ }^{296}$ McLeod, Lesbian and Gay Liberation in Canada: a Selected Annotated Chronology, 1964-1975, 96.

${ }^{297}$ McLeod, Lesbian and Gay Liberation in Canada: a Selected Annotated Chronology, 1964-1975, 130.
} 
into the late twentieth century, ${ }^{298}$ The Body Politic is iconic, serving as Canada's first effective national gay political periodical, thereby being "the first real voice for queers in Canada" ${ }^{299}$; the publication was dedicated to gay liberation, and sought to explore intellectual, political, sexual, and social issues, ${ }^{300}$ and, given its national distribution, served a de facto communication between all activist bodies across the country during the 1970s and 1980s. ${ }^{301}$ The Body Politic was instigated by Toronto Gay Action (TGA) member Jearld Moldenhauer in September of 1971, when he announced at a TGA meeting that they should form a new gay newspaper; this had been something under consideration since the 'We Demand' march on Parliament Hill that August, and the initial planning session for a paper that would reflect gay consciousness and community took place at this time. ${ }^{302}$ The result of this session would be The Body Politic, which went on sale in October 1971 and saw five thousand copies distributed across the nation. ${ }^{303}$ The Pink Triangle Press (PTP) was established in 1975 as a non-profit meant to cover the costs of the publication; PTP thought it would broaden readership in 1984 with Xtra!, an upbeat tabloid that saw circulation both within and outside Toronto. ${ }^{304}$ That said, faced with financial pressures, Pink Triangle Press had to reevaluate its future, ultimately deciding to close The Body Politicone publication that included all topics - to instead focus on growing other publications. ${ }^{305}$ With this, Xtra! - the more accessible and less politically minded publication - would evolve into a gay newspaper that would begin to take on more political content, and even expanded into

\footnotetext{
${ }^{298}$ See: McLeod, Lesbian and Gay Liberation in Canada: a Selected Annotated Chronology, 1964-1975, 258-276; McLeod, Lesbian and Gay Liberation in Canada: a Selected Annotated Chronology, 1976-1981, 794-852.

${ }^{299}$ Knegt, 70.

300 Jamie Bradburn, "Historicist: I Sing The Body Politic," Torontoist, February 14, 2005. https://torontoist.com/2015/02/historicist-i-sing-the-body-politic/.

${ }^{301}$ Knegt, 70.

${ }^{302}$ McLeod, Lesbian and Gay Liberation in Canada: a Selected Annotated Chronology, 1964-1975, 78.

${ }^{303}$ McLeod, Lesbian and Gay Liberation in Canada: a Selected Annotated Chronology, 1964-1975, 82.

${ }^{304}$ Jamie Bradburn, "Historicist: I Sing The Body Politic," Torontoist, February 14, 2005. https://torontoist.com/2015/02/historicist-i-sing-the-body-politic/. 305 Ibid.
} 
separate editions for Ottawa and Vancouver in $1993 .{ }^{306}$ Indeed, this paper "combined cheeky fun with hard-hitting journalism that both championed and chronicled the struggle for marriage equality, transgender rights, sexual liberation and more. ${ }^{307}$

\section{Community Opinions For and Against Legalizing Same-Sex Marriage}

Before moving on to investigating how the Canadian gay press covered the issue of marriage equality, it is necessary to first consider the opinions for and against the legalization of same-sex marriage that emerged at the height of the debate.

\section{For Legalizing Same-Sex Marriage}

Claire Young and Susan Boyd analyzed the briefs and testimonies presented Canadian Committee Hearings on Same-Sex Marriage in 2003 to reveal the arguments made by the supporters of marriage equality. "It's the Law" - a phrase utilized by Egale throughout the marriage equality debate - captures the rationale of one major argument: essentially, to deny lesbian and gay couples the same marriage rights as heterosexual couples is discriminatory and a violation of Charter rights. ${ }^{308}$ Indeed, civil unions and registered domestic partnerships - an option presented in the Canadian Department of Justice Discussion Papers on Same-Sex Marriage - were seen to be inadequate by many; marriage, as litigant René LaBoeuf stated, was a 'gold standard' of conjugal relationships, thus highlighting the argument made about the symbolic significance. ${ }^{309}$ This was accompanied by supporters advancing the rhetoric of necessity for the freedom of choice, as exemplified by the Canadian Union of Public Employees

\footnotetext{
${ }^{306}$ Ibid.

${ }^{307}$ David Rider, “Gay Newspaper Xtra to Stop Printing, Go Digital Only,” Toronto Star, January 14, 2015 , https:/www.thestar.com/entertainment/2015/01/14/gay-newspaper-xtra-to-stop-printing-go-digital-only.html (accessed August 17, 2019).

${ }^{308}$ Claire Young and Susan Boyd, "Losing the Feminist Voice? Debates on the Legal Recognition of Same Sex Partnerships in Canada," Feminist Legal Studies 14, no. 2 (2006): 227.

${ }^{309}$ Young and Boyd, 230.
} 
and the New Democratic Youth of Canada. ${ }^{310}$ Additionally, pro-marriage equality submissions often invoked images of sameness and assimilation, such as the idealized traditional norms of family, in an effort to make the point that lesbian and gay partnerships are the same as those of heterosexual couples; for example, witnesses focused on the traditional nature of their relationship, while Egale's brief featured portraits of couples that stressed their similarity to heterosexual couples. ${ }^{311}$ On a similar note, same-sex marriage proponents advanced claims that its existence would strengthen marriage and nuclear family. ${ }^{312}$ Young and Boyd mention that debating the merits of marriage legislation "appears to limit the opportunity to do more than simply accept the proposal that same-sex marriage be legalized. Any more nuanced an approach might be taken as evidence by opponents that the concept of same-sex marriage is indeed flawed and should not go forward. Most lesbians and gay men and feminists were unwilling to take that risk." ${ }^{313}$ Nick Mulé offers that this reductionist strategy of limiting the debate to traditional (i.e. opposing marriage equality due to traditional morals and beliefs) and liberal (i.e. supporting marriage equality based on concepts of equality and human rights) perspectives created a clearcut schism between those for and against marriage equality; as a result, "liberationist voices had difficulty being heard due to the restrictive parameters of the debate, creating a false sense of community unanimity on the issue." 314

\section{Against Legalizing Same-Sex Marriage}

Concerns about the legalization of same-sex marriage in Canada revolved around the consequences of not challenging the status quo and the assimilation of same-sex couples into a

\footnotetext{
${ }^{310}$ Young and Boyd, 228.

311 Young and Boyd, 228-229.

${ }^{312}$ Young and Boyd, 230.

${ }^{313}$ Young and Boyd, 232.

${ }^{314}$ Nick J. Mulé, "Same-sex marriage and Canadian relationship recognition-One step forward, two steps back: A critical liberationist perspective," Journal of Gay \& Lesbian Social Services 22, no. 1-2 (2010): 78.
} 
heteronormative society. Mulé advances that, in situating marriage equality as a human rights issue, the negative sociocultural implications marriage has on those outside this institution is ignored; consequentially, the social pressures of a couplist society are able to replicate, for there is no effort made to critique or disrupt the notion of marriage with more inclusive concepts that take into account of non-normative relationship structures that do not include marriage. ${ }^{315}$ That said, an outcome of legalized same-sex marriage is that those whose same-sex relationships resemble the traditional heterosexual model reap the advantages of this model, while a failure to do so results in ones' further marginalization. ${ }^{316}$ As Gayle Rubin's concepts of 'The Charmed Circle' and 'The Outer Limits' demonstrate, a hierarchy of sexual values exist within a heteronormative society, which work to maintain power and privilege, demarcating 'good' and 'bad' sexuality as a result. 'The Charmed Circle' requires that for sexuality to be 'good', 'normal', and 'natural', it must be heterosexual, marital, monogamous, procreative, noncommercial, coupled, relational, within the same generation, and 'vanilla ${ }^{, 317}$ On the contrary, the 'The Outer Limits' conceptualizes 'bad', 'abnormal', or 'unnatural' sexuality as anything that violates the aforementioned traits - such as homosexuality, unmarried relations, promiscuity, non-procreative and commercial sex. ${ }^{318}$ This construct positions the heterosexual, married, monogamous individual above all others, and serves as the standard to which adult relationships are held up; the further from this requirements one is, the less viable one's relationship is deemed by heteronormative standards. Consequentially, the availability of same-sex marriage restricts entrance into 'The Charmed Circle' to a distinct few, thereby establishing a boundary between

\footnotetext{
${ }^{315}$ Mulé, 80; Young and Boyd, 227.

${ }^{316}$ William N. Eskridge, "The same-sex-marriage debate and three conceptions of equality," in Marriage and SameSex Unions: A Debate, eds. Lynn D. Wardle et al. (Westport, CT: Praeger Publishers, 2003), 167-185.

317 Rubin, 152.

318 Ibid.
} 
'acceptable' and 'unfit' queer relationships. Furthermore, marriage equality's adherence to heteronormativity results in the alignment of queer people, spaces, and struggles with heterosexual cultural norms, and assumes that this wanted by queer people - that is, it encourages homonormativity. Lisa Duggan defines homonormativity as:

a politics that does not contest dominant heteronormative assumptions and institutions such as marriage, and its call for monogamy and reproduction - but upholds and sustains them while promising the possibility of a demobilized gay constituency and a privatized, depoliticized gay culture anchored in domesticity and consumption. ${ }^{319}$

Homonormativity is cause for concern, for it means that those who willingly assimilate into heteronormative structures come to receive more rights and privileges than those who chose not to or cannot. ${ }^{320}$ As a result of privileging homonormativity, there is decreased solidarity within the LGBTQ community, as certain queer issues become more visible than others. Derek M. Bolen notes that activism founded in homonormativity does not serve the fight against transgender discrimination, homelessness among LGBTQ youth, job housing and discrimination based on sexuality and gender, bisexual erasure, and inequalities at the intersections of race, gender, sexuality, socioeconomics, and nationalism. ${ }^{321}$

\section{Evidence from Interviews with Activists}

In order to get as accurate an understanding of the causes of shifts in framing as possible, and to gain additional insight into how stories about the legalization of same-sex marriage were constructed as well, it is imperative to feature perspectives of Canadian gay activists who were

\footnotetext{
${ }^{319}$ Lisa Dugan, "The New Homonormativity: The Sexual Politics of Neoliberalism," in Materializing Democracy: Toward a Revitalized Cultural Politics, eds. Russ Castronovo, Dana D. Nelson (Durham, NC: Duke University Pres, 2002), 179.

${ }^{320}$ Bradon Andrew Robinson, "Heteronormativity and Homonormaitivity," in The Wiley Blackwell Encyclopedia of Gender and Sexuality Studies (2016): 1-3. doi:10.1002/9781118663219.wbegss013. See as well Duggan (2002, 2003) and Susan Stryker (2008).

${ }^{321}$ Derek M. Bolen, "Homonormativity," in The SAGE Encyclopedia of LGBTQ Studies, (Thousand Oaks, CA: SAGE Publications, 2016), 543.
} 
active during the late-twentieth and early twenty-first century. The five participants interviewed include: Gary Kinsman (queer and anti-capitalist activist, author, and researcher), Gilles Marchildon (former Executive Director at Egale Canada, 2003-2006), Tim McCaskell (former member of The Body Politic, founding member of AIDS ACTION NOW!, spokesperson for Queers Against Israeli Apartheid), David Rayside (activist and academic), and Tom Warner (founder of the Gay Students' Alliance at the University of Saskatchewan, The Gay Community Centre of Saskatoon, and the Gay Alliance Toward Equality).

\section{Topic 1: Framing Marriage Equality}

When asked to reflect upon the shift in visibility and representation that took place in the past several decades, respondents identified many of the same events and offered similar rationales to help explain their occurrence. Tom Warner observed that, in the 1970s and well into the 1980s, there was not much attention given to LGBTQ issues by the Canadian mainstream press:

Every once in a while there would be a feature article or a columnist [who] would do something. Or when there was some legislation, like the amendment to the Human Rights Code, and then of course there would be very intense coverage for the period of time that that was in the legislation and being debated. But then there wouldn't really be much after that. Or when the bathhouse raids occurred, then there was a lot of media coverage and attention at that time around the raids the reactions of the communities to it, and a follow up of some of the court cases as they were going through. And the overall policy of the police and the relation to the police with the gay and lesbian community at the time. ${ }^{322}$

During this time, when LGBTQ issues did appear in the pages of newspapers, one could expect them not to be the most supportive; when controversial events emerged, such as the murder of Emanuel Jaques and the emergence of AIDS, the queer community were framed as threats to

\footnotetext{
${ }^{322}$ Tom Warner (gay rights activist, former Human Rights Commissioner) in discussion with the author, November $7^{\text {th }}, 2018$.
} 
public safety. ${ }^{323}$ That said, the turning point for representation was marked by the bathhouse raids and the AIDS epidemic; increased visibility - in part because of individuals coming out publicly about their health status, and also by way of AIDS activism - made clear that the community had a legitimate set of demands that deserved to be treated seriously and with respect. ${ }^{324}$ Commenting on the bathhouse raids of 1981, Kinsman offers:

One of the things that the mass resistance to the Bath Raids does in February 1981 is, I think, the police had every expectation that the mainstream media would, basically, be on side with them, and that's not how it worked out because the media was actually forced to take account of these huge mass demonstrations that were organized. So, the media actually raised some critical questions about that. Which, is not to say that everything was wonderful and good in terms of media coverage, but there's ways in which social movements actually impact on and transform the way in which media coverage takes place. $^{325}$

Rayside confirms this, pointing out that, "police raids came to be an important turning point, although it took a while for that to really translate into supportive reporting. But still, there was an ear opened to the disadvantages politically and legally faced by sexual minorities, most obviously gay men at the time, but to some degree lesbians as well." ${ }^{, 326}$ When it came to the transition in the discussion of AIDS, McCaskell comments that, in this context, a victim frame was placed on those with the condition, positioning the as people that needed to be protected rather than reviled ${ }^{327}$; included in this framing is a sense of pity and compassion, which was represented in depictions of gay men caring for each other - non-sexualized images that

\footnotetext{
${ }^{323}$ Tim McCaskell (former member of The Body Politic, founding member of AIDS ACTION NOW!) in discussion with the author, October $24^{\text {th }}, 2018$.

${ }^{324}$ David Rayside (activist and academic), in discussion with the author, October 12 $2^{\text {th }}, 2018$; Gary Kinsman (Queer and Anti-Capitalist Activist, researcher) in discussion with the author, November $1^{\text {st }}, 2018$.

${ }^{325}$ Gary Kinsman (Queer and Anti-Capitalist Activist, researcher) in discussion with the author, November $1^{\text {st }}, 2018$

${ }^{326}$ David Rayside (activist and academic), in discussion with the author, October 12 $2^{\text {th }}, 2018$; Gary Kinsman (Queer and Anti-Capitalist Activist, researcher) in discussion with the author, November ${ }^{\text {st }}, 2018$.

${ }^{327}$ Tim McCaskell (former member of The Body Politic, founding member of AIDS ACTION NOW!) in discussion with the author, October $24^{\text {th }}, 2018$.
} 
Kinsman suggests contributed to a shift in perspective. ${ }^{328}$ Following the establishment of the

Charter and the beginning of amendments to provincial Human Rights, according to McCaskell:

...the legal architecture of the Charter was changing the terms of proposition because it suddenly became framed as a question of equality. And it was the Charter that put kind of the equality frame in place as a judge of all laws and institutions, right? So that this notion of equality became suddenly foremost whereas in more conservative times, inequality is kind of taken for granted. Of course women aren't as good as men, right? Of course women shouldn't be paid as much as men. Of course a heterosexual family that produces children is better than somebody shacking up with somebody else of the same sex. All of these kinds of inequalities that are seen as common sense suddenly become questioned because of that kind of change in legal architecture. ${ }^{329}$

Neoliberalism is also perceived as having a role to play in the change in media representation.

Kinsman adds to this by suggesting the legalization of same-sex marriages privatizes same-sex relationships and sexualities, which contributes to a non-moral, conservative, neoliberalism that operates on the notion that, "in some ways if they wanna get married, they're gonna fit right in. Right? They're gonna be happy consumers. They're gonna buy things. They're not gonna raise the contestative questions that they used to raise, so it's actually in our interests to facilitate this. ${ }^{330}$ For businesses to become welcoming of same-sex couples helped contribute to a shift in representation; David Rayside offers, "So among the factors that I think contributed to a media shift is that for the business community, it became less of a contingency issue. They realized the costs were modest. The symbolic pluses were becoming more significant. The community was much more established, more visible. They then had these areas, zones, within big cities that were LGBT sort of dominated." ${ }^{331}$

\footnotetext{
${ }^{328}$ Gary Kinsman (Queer and Anti-Capitalist Activist, researcher) in discussion with the author, November $1^{\text {st }}, 2018$.

${ }^{329}$ Tim McCaskell (former member of The Body Politic, founding member of AIDS ACTION NOW!) in discussion with the author, October $24^{\text {th }}, 2018$.

${ }^{330}$ Gary Kinsman (Queer and Anti-Capitalist Activist, researcher) in discussion with the author, November 1 $1^{\text {st }}, 2018$.

${ }^{331}$ David Rayside (activist and academic), in discussion with the author, October 12 ${ }^{\text {th }}, 2018$; Gary Kinsman (Queer and Anti-Capitalist Activist, researcher) in discussion with the author, November $1^{\text {st }}, 2018$.
} 
By the time marriage equality became a prominent issue in Canada, the media became much more neutral, fair and balanced. That said, Kinsman and Rayside encourage us to direct our focus to the events, and how they themselves had a role in dictating media framing. Kinsman states:

The media frames don't just float around on their own. They're all related to social struggle. For instance, the successful resistance to the Bath Raid in Toronto in the early 1980's actually did change media framing around gay men, and to some extent lesbians as well. So, that people were actually organizing around same sex spousal benefits, family recognition rights, and eventually marriage, that had an impact on media framing well. ${ }^{332}$

Rayside compliments this when he suggests, "A lot of the demands were fairly straight forward in those years. 'Help us stop dying. Eliminate explicit discrimination. Extend to us benefits that are extended to heterosexual families.' At some level, easy to grasp. So framing may have helped, but also the issues were by their very nature not so very complicated to grasp.",333 Rayside also reminds us that the Courts themselves had a role in influencing framing: "The fact that the Supreme Court of Canada would say well yes, discriminating against this minority is analogous to discriminating against women or racial minorities or people with disabilities. That helped and made the issues clear. So it wasn't just advocates, activists framing the issues. It was also the courts in effect, framing the issue as a basic civil rights issue."334

The activists' responses enable us to better understand why the treatment of LGBTQ people by the Canadian mainstream press improved overtime. From their perspective, beginning in the 1980s, the increasing visibility of community members who were advocating for themselves amidst events that revealed their political and legal marginality humanized them, resulting in burgeoning sympathy. Echoing the viewpoints of the journalists interviewed, the language and framing used by the courts in response to marriage equality was seen to have an

\footnotetext{
${ }^{332}$ Gary Kinsman (Queer and Anti-Capitalist Activist, researcher) in discussion with the author, November $1^{\text {st }}, 2018$.

${ }^{333}$ David Rayside (activist and academic), in discussion with the author, October $12^{\text {th }}, 2018$.

${ }^{334}$ Ibid.
} 
influence in how the Canadian mainstream press would come to take up the issue in their pages.

That said, an additional insight provided by the activists that was not touched on by the

journalists was the role of neoliberalism and heteronormativity in making marriage equality a

non-threatening phenomenon to the status quo, thereby making it an appropriate subject matter to gave visibility to.

Topic 2: Participation in Interview with the Media

\section{Gary Kinsman}

While Kinsman provided expert testimony about LGBTQ issues in the past and had even presented at the Canadian Committee Hearing on Same-Sex Marriage in 2003, his radical analyses did not align with discernible arguments for or against same-sex marriage. Young and Boyd mention that, in appearing before the court to testify for the abolition of state sanctioned marriage, "[Kinsman] addressed the patriarchal nature of marriage, noting that marriage is the most privileged of social relations and that state institutionalized recognition of marriage is itself a state practice of discrimination against other forms of social and sexual relationships, such as single-parent-headed households. ${ }^{\text {} 335}$ The committees' confusion about Kinsman's testimony demonstrates how ideas about the abolition of marriage and regulating social relationships "seemed outside the imagination of the committee, and indeed, most witnesses. ${ }^{, 336}$ As a result of his position, he wasn't generally contacted to comment on marriage equality:

...in terms of the same sex marriage struggles, I was just not within the frame of reference because people knew that I would actually, potentially say critical things to what they wanted to achieve legally, even though I had all this expertise around those questions. They would know that even if they didn't ask me these questions that it was quite possible that the lawyers on the other could. So, I mean, I know that I was contacted by some media every once in awhile around some of these questions. But, none of that

\footnotetext{
${ }^{335}$ Young and Boyd, 232.

${ }^{336}$ Ibid.
} 
ever really panned out in any, sort of, central way. I mean there really was this monolithic approach around same sex marriage. ${ }^{337}$

Indeed, organizations rallying for marriage equality did not offer Kinsman as a media contact:

I would not have been one of the people who the media would have gone to around same sex marriage because usually the same sex marriage organizations would tell the media who to talk to. Right? So, you'd have people who would be much more predisposed to say similar things to them. They would not refer people to me. So, some media would approach me who knew me from before. Right? But, I don't remember any of that getting any significant traction." 338

In being public about his 'radical' perspectives about the institution of marriage, he was quite distinct from many other activists: "I think a lot of activists who had questions and concerns about this particle perspective ended up keeping it mostly to ourselves, or just talking to ourselves about it rather than making it a big public issue because none of us really wanted to be seen as opposing these struggles for formal equality even if we had major questions about them."339

\section{$\underline{\text { Gilles Marchildon }}$}

As part of Egale's lobbying efforts, there was a concerted effort to have their voice heard by way of the media. Fortunately for the organization, being located in by Parliament Hill in Ottawa afforded them the opportunity to address the media gathered there quickly as events occurred. This was critical, as it opened up Egale to be a readily available source for journalists covering a story, thereby increasing its fairness and balance; Marchildon offers an example of how this might play out: "For instance if a conservative member of Parliament had said something stupid about same-sex marriage, we had cultivated a response very quick because journalists, in an attempt to present the balanced story, would often seek out our opinion on

\footnotetext{
${ }^{337}$ Gary Kinsman (Queer and Anti-Capitalist Activist, researcher) in discussion with the author, November $1^{\text {st }}, 2018$.

${ }^{338}$ Ibid.

${ }^{339}$ Ibid.
} 
pronouncements. ${ }^{340}$ The ease of access to an attentive journalistic audience was a pleasant surprise for Marchildon; as he reflects, "I do remember being struck by how 'there' we were. We could walk the four or five blocks between our office and Parliament Hill. We were able to go to the press theater and immediately potentially have an audience, a national media audience, for our messages. That's pretty...I think that speaks so well of Canada's democracy and I think a strong media is part of that. ${ }^{341}$ Indeed, holding press conferences at the National Press Theatre was a conventional tactic that enabled Egale to share their narrative:

I seem to recall that we would... I was going to say we were there maybe once a month at least, but actually it wasn't that regular. There'd be two months where nothing happened and then there'd be a week where we were doing two or three press conferences or at least one press conference but issuing two news releases. It really depended on the event. There were times when what we called the religious right would be on the warpath and had issued a statement or had done... Carried out lobbying days. And so we wanted to respond to that immediately. That would have been a more intense period. ${ }^{342}$

These press conferences would often primarily focus on Egale issuing statements, but frequently made efforts to include a range of peoples and perspectives; for instance, the couples and their lawyers fighting for marriage equality, unions, and Members of Parliament across party lines were amongst those given an opportunity to address the press. "We often would make an effort to include others, to tangentially demonstrate that the message was being heard and picked up and supported by a cross-section of Canadians," Marchildon recalls. ${ }^{343}$ Interestingly, Marchildon also utilized tactics used by his predecessor, John Fisher, during his visits to Parliament to acquire additional interest from the media:

I even remember a trick I learned from John Fisher, my predecessor, who was Executive Director at a time when there was a lot less interest in LGBT issues. He would just plunk himself in the middle of the... Maybe not quite the middle but the foyer where politicians

\footnotetext{
${ }^{340}$ Gilles Marchildon (former Executive Director at Egale Canada) in discussion with the author, December $2^{\text {nd }}$, 2018.

${ }^{341}$ Ibid.

${ }^{342}$ Ibid.

${ }^{343}$ Ibid.
} 
would usually do scrums with media. All he had to do was to... And he developed relationships with some of the media so that if one of them was talking to him and had their microphone pointed towards him, and if he was speaking, by curiosity others would start... Other members of media would start collecting around him. Before he knew it, he had six or seven national media recording what he was saying at least. May not necessarily [be broadcasting] it later, because that's the whole editorial process. ${ }^{344}$

Indeed, even if there was a news conference scheduled by Egale, Marchildon would employ this technique to grab the attention of journalists; through making interesting and valid points, Marchildon could offer the media additional content that could be used in the construction of a news story. Indeed, Marchildon's perspective on how the media treated him and Egale during his time with the organization was summarized thusly:

I thought media were fairly good about giving us an opportunity to express ourselves. They were pretty... And I think quite possibly because many of them were somewhat sympathetic to the cause. I know sometimes right-wing politicians will be critical of the media suggesting that they have a bias. Of course they're going to be. They have opinions. Generally, I think they tend to be a little bit more liberal in terms of their views. But they are still professionals who I think make... That keep a really good balance in their reporting. ${ }^{345}$

That said, Marchildon occasionally appeared on talk show radio, which was certainly less measured and calm than the press conferences on Parliament Hill:

It's meant to be provocative and it was always a debate whether or not to participate because on the one hand you knew that the host, particularly in certain radio stations or certain hosts had their reputation, you knew that they were against you. But at the same time, it was a challenge to roll up your sleeves and get in there and talk maybe not as vulgarly but have the debate on another level. ${ }^{346}$

However, this platform was viewed by Marchildon as yet another way to convince the hearts and minds of Canadians across the country to support marriage equality.

\footnotetext{
${ }^{344}$ Ibid.

345 Ibid.

346 Ibid.
} 


\section{$\underline{\text { Tim McCaskell }}$}

McCaskell spoke of his media experience in relation to his years of activism; while he wasn't regularly contacted regarding marriage equality (in fact, he recalls one interview with the National Post in which he commented on not wanting to get married, which went well as he was speaking with a known acquaintance) he was a source of information for other issues, and as such, came to acquire an awareness of how media operated that informed how he functioned in interviews. Commenting on engaging with reporters, McCaskell offered:

...the thing about media was that you always had to be thinking three steps ahead before your mouth opened because you needed to try to figure out what their frame was going to be and how what you were gonna say was taken up. So your answers had to be clear and concise. If you told them anything, if you're a reporter and we just had this conversation, what you would report in the Star then tomorrow morning would be unrecognizable by me because I'm talking about kind of connections and complex things and it's like, they can't deal with that, right? The media story has got a certain kind of frame and you've got like an opening paragraph, you've gotta delete this little stuff in the middle and then you've got kind of the closing piece. And you can only have basically one message at a time. $^{347}$

Essentially, for McCaskell, “...there's a way of kind of having to deal with the media, to know what their constraints are and how they put together stories so that you can fit into that so that when the story actually comes out, it's somehow recognizable in terms of what you wanted to say." ${ }^{348}$ Any hostility in the press, McCaskell reflected, was exhibited more by columnists than reporters themselves - indeed, McCaskell recalled an instance where, after a demonstration, a reporter from The Toronto Sun apologized for the paper's treatment of LGBTQ issues. From his perspective, reporters received training that resulted in fair and balanced reporting, and he saw this enacted as both activists and opponents would be used as sources; this was first noticed by

\footnotetext{
${ }^{347}$ Tim McCaskell (former member of The Body Politic, founding member of AIDS ACTION NOW!) in discussion with the author, October $24^{\text {th }}, 2018$.

${ }^{348}$ Ibid.
} 
McCaskell in the late 1970s with the Anita Bryant visit to Canada, with reporters scrambling to speak to community members in order to be able to accurately present both sides of this story.

\section{$\underline{\text { David Rayside }}$}

Having been an activist for years prior to the amendment of Ontario's Human Rights

Code in 1986, it was around this time that Rayside opened himself up to engaging with the media. While also teaching and researching on sexual diversity, journalists were primarily interested in him due to his activism. In his first interview, he, alongside an activist colleague, was pitted against opponents; while stressful, this experience gave him the confidence to continue doing media appearances. By the time he became to be contacted about the issue of marriage equality, he developed an approach for speaking with journalists:

My approach by then to reporters was first of all, what we all do with a reporter, try to figure out whether they have an angle. And obviously it would depend on what media outlet, and I did occasionally get interviewed by the Sun. But by not crazy people. So I decided that one of my roles as an academic as well as a Partisan, was to provide background. And take a long time, like half an hour with a reporter. More if necessary and say, "Well, that's not really the right question - I'll tell you why." Or, "That's an unfortunate frame and you didn't develop it. It's your editor that did, but here's a more interesting question." So I tried to be sympathetic with reporters to recognize that in our media age in particular, reporters don't have the luxury of being specialists... ${ }^{349}$

In due part because of his academic-interests and his having written an affidavit for Halpern, et al. v. A.G. Canada (2000), Rayside ensured he took time to explain and offer evidence for the developing events of marriage:

So you have to background. It doesn't help if you're impatient with what they don't know. I would spend a lot of time with them. I would then try to use evidence. So I would point out that businesses are rapidly shifting towards accepting this as a reality and there's some religious institutions, there are. And same sex relationships are widely recognized anyway because of the peculiarities of the common law recognition in this country. So marriage at some level is not really that big of a deal. It doesn't force any religious institution. I'm just trying to be reasonable. I just tried to say yeah, there's opposition

\footnotetext{
${ }^{349}$ David Rayside (activist and academic), in discussion with the author, October $12^{\text {th }}, 2018$.
} 
because this has lots of symbolic loadings. But, at some level, around LGBT rights, the barn door was closed too late. We're on this track and it's inevitable. ${ }^{350}$

That said, despite these efforts, Rayside felt reporters didn't find it useful because he didn't offer short, catchy clips; however, he was always treated well by journalists.

\section{$\underline{\text { Tom Warner }}$}

Reflecting on his overall experience with media, Warner was satisfied:

Overall, generally I would say yes. I was satisfied with it. They had reported accurately, or reasonably accurately, in terms of what I had said or the point of view that I was putting forward. There were a couple of times when I thought they put it into a context that I didn't really fully intend, but it wasn't enough to say they completely distorted what I had to say. Often I would be contacted to comment on something, like a court decision, right? What are the implications of this for the community? What does it mean for us? What does it mean for the law generally or Canada generally? Is it a good thing, is it not a good thing? So a lot of it was just pretty much factual and straightforward. ${ }^{351}$

Echoing the experience of Marchilson, Warner spoke to the distinct differences that existed between print and radio:

Mostly for the print journalists and the broadcast journalists for the most part, it was neutral...It was more problematic with some of the radio stations, and particularly some of the talk shows. I know Talk Radio 1010 at one point in time was really quite negative in terms of what they reported and what they would allow people calling into their shows to say about gays and lesbians. Quite offensive. I don't know if they would even allow it today, but back then they did, right? So those were more of a problem. ${ }^{352}$

Warner recalled an instance when he was asked to come onto 1010 to discuss the legislative debate in 1994 surrounding Bill 167, only to be surprised that he was set up to have a conversation with an anti-gay advocate; he would've been fine with this if he had been told in advance, but it felt, to him, like he had been setup to create conflict. Despite this, Warner

\footnotetext{
${ }^{350}$ Ibid.

${ }^{351}$ Tom Warner (gay rights activist, former Human Rights Commissioner) in discussion with the author, November $7^{\text {th }}, 2018$.

352 Ibid.
} 
believed the media were, generally, professional, fair, neutral, and accurate, and he never was seriously misquoted or had anything he said distorted or presented out of context.

Through learning about the experiences the interviewees had with the Canadian mainstream press, it is possible to garner additional insight into how LGBTQ community members were treated by the media. Journalists' commitment to maintaining fairness and balance becomes particularly apparent here; activists noted that they were called upon to offer their viewpoints in a bid to ensure that journalists produced balanced pieces of work. However, it should be noted that those whose opinions did not fit neatly into the traditional or egalitarian frame advanced by both the courts and in the presses were not approached for comment. It could also be suggested that, given fear amongst those community members who critiqued marriage equality that they would be seen poorly, it is quite likely that there would not have been many individuals who could be consulted about their opinions. That said, those approached for an interview were prepared with a strategy for how to approach their discussions with journalists, ranging from increasing their accessibility in order to increase the likelihood of being interviewed, to considering how to craft responses to ensure they would not only be received by journalists accurately, but that they would even make it in an article, to even challenging the journalist to ask particular questions and alter frames. Ultimately, the Canadian mainstream press treated the activists professionally - a stark difference from radio hosts, who attempted to manipulate their interviewees into engaging in combative discussions with ideological opponents.

\section{Analyzing Pieces Featured in The Body Politic and Xtra!}

We can begin to consider how community discussion about marriage equality was represented in the pages of the Canadian gay press; this is done to determine the degree to which 
their content was similar to the national newspapers. This dissertation will focus on two publications - The Body Politic and the paper that was expanded upon to replace it, Xtra! - given the publications' notoriety and reach within the nation.

It comes to no surprise that, given that the publication was operated by gay liberationists, the subject of marriage equality did not make the pages of The Body Politic. An unsigned editorial featured in the publications' fourth issue in 1972 made their stance on the issue abundantly clear:

Gay liberation is a socio-political force working for a society free of unnecessary repression and oppressive political structures. As gay liberationists, we challenge the dominance of the nuclear family as the basic political unit of institutionalized sexism. Sexism, the discrimination against, exploitation and/or objectification of people because of their sex or sexual preference, is a major mechanism whereby people are oppressed and perpetuate oppression through their own conditioned attitudes. The socializing into role playing of everyone via the nuclear family, is the foundation of the sexist social structure, reproduced in and perpetuated by every other social institution. As gays, our very existence challenges the major behavioural manifestations of the status quo. ${ }^{353}$

The closest would be an article published in 1986 describing Section 15 coming into effect in the previous year; the article, which focused on sexual orientation being excluded as a grounds for discrimination and the hopefulness individuals had in the open-ended nature of the wording, referenced Lynn King, a Toronto-based feminist and lawyer, who pondered about the potential for the Charter to be used by gays to convince the courts that laws - such as those involving marriage - are discriminatory. ${ }^{354}$ Mentions of the marriage would be presented in terms of how the institution could privilege those engaged in it at the expense of those who are not, and how to remove oneself from it. For instance, one article covered the issue of housing of queer individuals, noting how bylaws implicated habitation in a manner not experienced by those who

\footnotetext{
${ }^{353}$ Unsigned editorial, No title, The Body Politic, May/June 1972, 2.

${ }^{354}$ Michael Totzkey, "Cause For a (Small) Celebration," The Body Politic, September 1985, 15 \& 17.
} 
were married. ${ }^{355}$ Additionally, in June of 1982, the publication included an excerpt from Gay

Fathers: Some Of Their Stories, Experience, and Advice - published by the group Gay Fathers of

Toronto, which outlined how one could come out to their wife and dissolve their marriage.

With The Body Politic ceasing publication in 1987 - long before the discussions about relationship recognition that would emerge in the 1990s - they could not have commented on these developments; however, given their liberationist stance, one could imagine they would have been unabashedly critical about marriage equality. Would Xtra! - becoming more political in the wake of The Body Politic's demise - take up the mantle? Indeed, Xtra! offered news reports about major developments, like their mainstream peers; in addition to this role as an informer, the publication also sought to provide in-depth explanations about what these developments meant and offer advice on how to navigate the legal waters. Examples of this include: a series of articles published post-M. v H. explained what legal responsibilities spouses now had ${ }^{356}$; an article published in fall 2001served as a guide to all the current marriage challenges taking place in British Columbia, Ontario, and Quebec ${ }^{357}$; a guide as to what couples in Ontario and British Columbia needed to know about the differences between marriage in common-law post-legalization in these provinces ${ }^{358}$; a piece outlining the difference between two groups lobbying for the federal government to pass legislation making same-sex marriage nationwide - Canadians For Equal Marriage and Equal Marriage for Same-Sex Couples ${ }^{359}$; a timeline

\footnotetext{
${ }^{355}$ Lee Zaslofski, "Housing: A Family Affair," The Body Politic, October 1985, 17.

${ }^{356}$ Brenda Cossman, "The Full Monty: Spousal Rights Means You'll Be On the Hook For Years to Come," Xtra!, April 8, 1999, 11.

${ }^{357}$ John Sinopoli, “To Court, To Court: Our Guide to All These Marriage Challenges," Xtra!, October 31, 2001, https://www.dailyxtra.com/to-court-to-court-45902.

${ }^{358}$ Tanya Gulliver, "Hitching \& Shacking: A Homo's Guide to Marriage Versus Common Law," Xtra!, September 4, 2003, 10-11; Andrea Lewandowski, "Marriage 101: Learn Your Way Around Common Law Before You Tie the Knot," Xtra!, August 13, 2003, https://www.dailyxtra.com/marriage-101-43447.

${ }^{359}$ Ian Mackenzie, "Equal, Equal, Equal, Equal: How Do You Tell The Marriage Groups Apart?," Xtra!, December 10, 2003, https://www.dailyxtra.com/equal-equal-equal-equal-42732.
} 
outlining major developments in the bid for marriage equality ${ }^{360}$; and reprints of Prime Minister Paul Martin's address on the Civil Marriage $A c t^{361}$ and the text of this bill. ${ }^{362}$

In terms of opinion-based articles about the legalization of same-sex marriage in Canada, Xtra! featured a limited amount of them; that said, the publication did not shy away from featuring pieces that were critical of marriage. Two opinions were published shortly after Evan Wolfdon - an American lawyer who argued the gay marriage case in Hawaii - visited Toronto in 1997 to speak about the need to fight for marriage equality. Nikki Gershbain notes that, "Today, the promotion of sexual freedom and diversity, the rejection of heterosexual values and alliances with other outsider communities have been, by and large, abandoned. Given a face-lift by the media and some of our own spokespeople, gay men and lesbians have been reinvented for the neo-conservative $1990 \mathrm{~s}^{\text {"363 }}$; she argues that, while same-sex couples will be pressured into legal coupledom for the same flawed reasons as heterosexual couples (i.e. economic security, familial approval, community support), it is imperative that they instead work to "build our own secular rituals. We must find queer ways to celebrate our relationships, acknowledging our chosen families, and foster our differences, without borrowing uncritically from straight culture and its traditional nuclear family." 364 Similarly, Tom Warner reflects upon his disappointment with the Coalition For Lesbian and Gay Rights in Ontario, who launched a campaign in 1989 that sought to see that people in same-sex relationships who want all the same rights, benefits, obligations, and responsibilities as heterosexual couples be able to do so; freedom of choice was key here,

\footnotetext{
${ }^{360}$ Tanya Gulliver, "Marriage Timeline," Xtra!, October 13, 2004, https://www.dailyxtra.com/marriage-timeline40820.

${ }^{361}$ Hansard Transcript, "Speech by Prime Minister Paul Martin: The Civil Marriage Act," Xtra!, February 15, 2005, https://www.dailyxtra.com/speech-by-prime-minister-paul-martin-39400.

${ }^{362}$ House of Commons of Canada, "The Text of the Same-Sex Marriage Bill: Here's What the Bill Says... and Doesn't Say,” Xtra!, February 16, 2005, https://www.dailyxtra.com/the-text-of-the-same-sex-marriage-bill-39401. ${ }^{363}$ Nikki Gershbain, "Waiting At the Altar: We Need Queer Ways to Celebrate Our Relationships \& Create Rituals," Xtra!, May 22, 1997, 37.

${ }^{364}$ Ibid.
} 
with the group advocating for a declaration or registration of the relationship necessary to gain legal status - indeed, there was never a call for same-sex marriages to be legalized. However, the group's consensus shifted, and ultimately grew to become a conservative movement for accommodation within the status quo; as he recalls, "too many people got involved with the issue out of a need to have the state legitimize their relationships and thereby give them respectability. Wolfson's recent visit to Toronto was simply another manifestation of this conservative drift in certain activist circles." 365 In light of this, Warner stresses that the notion that relationships must be legitimized or validated by heterosexuals be purged, and that the community be able to form their own relationships, on their own terms, without facing discrimination of harassment; he states, "at the very least, we can achieve this by expanding the legal definition of common-law relationships. Those in our communities who want the trappings of marriage...can have religious services if they want them. ${ }^{366}$ In response to the M v. H alimony case that, by early-1998, was before the Supreme Court, Kate Barker considered the debate over gay marriage within the community, carefully considering the potential for marriage to equalize but also continue to oppress, before ultimately suggesting that legalization will transform the institution of marriage for the better. ${ }^{367}$ Brenda Cossman offered a scathing critique of Egale, noting that the organization lobbied for 'respectable rights' only - including the legal recognition of gay and lesbian relationships - neglecting 'less respectable' issues such as censorship, sexuality, and age of consent; this leads Cossman to argue that its success is predicated on presenting an unthreatening face - the mainstream is presented with "a decent, fit and proper face of the gay

\footnotetext{
${ }^{365}$ Tom Warner, "Story of a Same-Sex Spousal Rights Strategy: Bandwagon Effect \& Media Attention Narrowed the Focus of the Campaign," Xtra!, June 5, 1997, 28.

366 Ibid.

${ }^{367}$ Kate Barker, "Let's Call the Whole Thing Off: The Debate Over Gay Marriage Splits the Community in Two," Xtra!, March 26, 1998, 23.
} 
and lesbian community", thereby deserting those who do not abide by the mainstream standards. ${ }^{368}$ In an editorial in January 2001, Eleanor Brown commented on how, in reporting on the weddings of Kevin Bourassa to Joe Varnell and Elaine Vautour to Anne Vautour, only The Globe and Mail featured the Vautour's kissing on the front page; however, Brown observed how the coverage of gay nuptials was done in a fairly open and positive manner, whereas stories of Canadian gay criminals was much more censored in discussing the subject's sexualities. This led Brown to argue that mainstream media will be more receptive to "the idea of good homosexuals and their lovely wedding, ${ }^{369}$ than talking about gay murder victims in closeted terms. In that same edition, Michel Dorge outlined the flaws of marriage and offers that, in light of discussions of legalization, this is the opportunity to take an alternative path and construct something new. ${ }^{370}$ Michelle Maloney Leonard raised the concern that the legal recognition of same-sex marriage is narrow-sighted, as it delegitimizes nonconforming relationship models. ${ }^{371}$ The publication sought to call random workplaces across the country in Fall 2003 to poll individuals on their thoughts on same-sex marriage and gay and lesbian rights, revealing moral and egalitarian rationales. ${ }^{372}$ Gareth Kirkby argued of the importance of allowing religious people to have the right to speak out against same-sex marriage, noting: "We've won over some 80 percent of Canadians to our struggle for liberation and equality. The other 20 percent may or may not be won over on the strength of how just our cause is. But we must win on the facts, by revealing our truths, our personal stories. Not by trying to silence those who disagree with our cause. ${ }^{373}$ Tanya

\footnotetext{
${ }^{368}$ Brenda Cossman, "No Sex, Please: National Lobby Group Stands Up For Respectable Rights Only,” Xtra!, February 25, 1999, 11.

${ }^{369}$ Eleanor Brown, "The Kiss," Xtra!, January 25, 2001, 9.

${ }^{370}$ Michel Dorge, "Memo To: Newlyweds," Xtra!, January 25, 2001, 11.

${ }^{371}$ Michelle Maloney Leonard, "Why Just Two Spouses?," Xtra!, June 26, 2003, 7-8.

372 Tanya Gulliver \& Paul Gallant, “Are We Stupid \& Squeaky? Marriage Could Be One Right Too Many?," Xtra!, October 01, 2003, https://www.dailyxtra.com/are-we-stupid-squeaky-43174.

${ }^{373}$ Gareth Kirkby, "The Right to Be Wrong: Religious People Have Right to Speak Out,” Xtra!, October 01, 2003, https://www.dailyxtra.com/the-right-to-be-wrong-43145.
} 
Gulliver offered that queer marriages are customizable, and do not have to follow the standard norms and procedures of their straight counterparts. ${ }^{374}$ In anticipation of the Supreme Court of Canada's ruling on if Parliament has the legislative authority to extend the definition of marriage to include same-sex couples, Tom Warner reminded readers that while many in the community were hopeful for a positive response, the idea that most queer Canadians want to get married is dubious; in fact, the questions raised by a radical minority should have been addressed throughout all proceedings, but were ignored - indeed, Warner asks whether the institution of marriage needs to exist? ${ }^{375}$ Paul Gallant critiqued those explanations by MPs against same-sex marriage in a comedic tone. ${ }^{376}$ Gareth Kirkby suggested, in response to neglecting to attempt to derail Bill C-2 (federal legislation that other queer groups noted would threaten freedom of speech, artistic expression, and the rights of teens to choose their own sexuality), Egale wasn't doing enough to attend to queer issues outside of marriage equality. ${ }^{377}$ In response to the House of Commons voting to affirm equal marriage rights for same-sex couples in June 2005, Alex Munter, of Canadians for Equal Marriage, wrote about how marriage equality was the right thing to do; after applauding politicians for having the courage to see marriage equality through, and for gay people who have lived openly and advocated for this change, Munter calls on Senate to pass the bill speedily, concluding:

In a generation, Canadians will look back on a time when lesbian and gay people were denied full citizenship, just as we look back on the days when women or Aboriginal people could not vote or times when Canadian citizens were interned because of ethnic origin. We will talk about these days and this battle. We will be proud, as Canadians, that we rejected rejection, that we ended exclusion, that we said to [gay, lesbian, bisexual and

\footnotetext{
${ }^{374}$ Tanya Gulliver, “Customize Your Love: Queer Marriages Aren’t Paint By Numbers,” Xtra!, October 30, 2003, 14.

${ }^{375}$ Tom Warner, "Simply Yes, Yes, Yes \& No? What the Supreme Court Should Have Said," Xtra!, December 8, 2004, https://www.dailyxtra.com/simply-yes-yes-yes-no-40464.

376 Paul Gallant, “Aunt Frances Waits With Bated Breath: Lessons Learned From Parliament's Marriage Debate," Xtra!, March 30, 2005, https://www.dailyxtra.com/aunt-frances-waits-with-bated-breath-39876.

377 Gareth Kirkby, "Egale Blows It: Didn’t Live Up to Promise on Bill C-2,” Xtra!, June 27, 2005, https://www.dailyxtra.com/egale-blows-it-39352.
} 
trans] people: there are no second-class Canadians, lesbian and gay people are full members of the community, without caveat or exceptions. We will long remember this proud day. ${ }^{378}$

Finally, in July 2005, Tanya Gulliver and Krishna Rau sought to answer the question, 'Where does the marriage vote fit into the history of lesbian and gay liberation in Canada?' by getting the responses of activists, including Jane Rule, George Hislop, and Gerald Hannon; their results are indicative of an ambivalence and muted response by community members ${ }^{379}$

Although The Body Politic ceased publication before relationship recognition really took off in the nation, one can imagine that, were they to comment of marriage equality, it would be through a liberationist lens. That said, Xtra! operated at the height of discussions surrounding marriage equality, and an analysis of its content is revealing of a publication that primarily sought to inform readers about current events and offer advice on how to respond; while editorials did not spell out Xtra!'s position on marriage equality, the editorial team made an effort to showcase both assimilationist and liberationist perspectives offered by contributors. Through this, the publication acknowledged the ideological division within the community, and allowed both perspectives to circulate amongst readers; indeed, this was done without editorializing Xtra!'s position, thereby allowing the publication to skirt any controversy (recall, as Kinsman said, the concern amongst community members to publicly denounce marriage equality).

\section{Conclusion}

Based on the evidence of this chapter, we can consider the mainstream coverage of the legalization of same-sex marriage in Canada as being somewhat accurate in reflecting the

\footnotetext{
${ }^{378}$ Alex Munter, “Gay Marriage Rights: The Canadian Thing to Do,” Xtra!, June 29, 2005, https:/www.dailyxtra.com/gay-marriage-rights-the-canadian-thing-to-do-39350.

${ }^{379}$ Tanya Gulliver and Krishna Rau, "How Does It Feel? The Meaning of the Marriage Vote for the Movement," Xtra!, July 5, 2005, 13.
} 
perspectives of the Canadian LGBTQ community. Crucially, reportage failed to discuss the dissent within the LGBTQ community regarding the viability of marriage equality - a debate rooted in the history of the gay liberation movement in the nation. A possible explanation for this is multifaceted. The assimilationist perspective came to drive LGBTQ activism in the latetwentieth and early twenty-first centuries, and fuelled the rights-based activism that followed. The egalitarian frame they projected was countered by the traditional frame in the courts and, consequentially, the press. It can be suggested that liberationist perspectives did not fit neatly into the ongoing discussions of marriage equality, and were thus neglected. It is also possible that, as suggested in the interviews, critics of marriage equality as a necessary activist endeavor were concerned about sharing their perspective in the mainstream press out of fear of isolating themselves amongst their peers and possibly giving fuel for traditional-minded opponents. On that note, in contrast to the mainstream press, the most prolific gay publication in the nation, Xtra!, did not editorialize their stance, but consistently made an effort to not only update readers on the state of marriage equality, but to include opinion pieces that addressed the debate. That said, the activists' revealed that they were aware of the importance of their voices to journalists who strove to present stories in a fair and balanced manner, and required their insights to do so. Interviewees echoed the explanations offered by journalists that a shift in treatment in covering LGBTQ-related issues - particularly marriage equality - had much to do with the increasing visibility of this marginalized community and their concerns; however, they also offered that those wanting marriage equality did not threaten to disrupt the status quo, and as such, was nonthreatening to the masses and, therefore, a palatable matter to cover. 


\section{Chapter 5: Conclusions, Discussion, and Suggestions for Future Research}

While this dissertion ends its analysis in July 2005 following the establishment of the Civil Marriage Act, it is imperative to stress that some political developments regarding samesex marriage in the nation took place since then. On the opening day of the federal election in late-2005, Conservative Leader Stephen Harper promised his government would hold a free vote on a motion to re-open the debate on same-sex marriage. ${ }^{380}$ According to CBC News, "the motion asked the government to introduce legislation to restore the traditional definition of marriage without affecting civil unions and while respecting existing same-sex marriages." ${ }^{„ 381}$ Following his election win, in December 2006, the motion to reopen the same-sex marriage debate was swiftly defeated in Parliament, with MPs voting 175-123 against it. ${ }^{382}$ Meeting with reporters after this defeat outside of the House of Commons, Harper stated, "I don't see reopening this question in the future." ${ }^{383}$ With this, the political issue of same-sex marriage in Canada was laid to rest, with debate not resurfacing since.

The next time same-sex marriage would be brought up in the world of Canadian federal politics was in September 2019, when Conservative Leader Andrew Scheer's past derogatory comments about same-sex marriage - made during the height of the debates in Parliament in 2005 when he was an MP - were brought to the public's attention by the Liberals. ${ }^{384}$ In response, Scheer did not attempt to apologize, but stressed that the question of same-sex marriage was

\footnotetext{
${ }^{380}$ Gloria Galloway and Brian Laghi, "Harper Reopens Same-Sex Debate," The Globe and Mail, November 30, 2005, A1.

${ }^{381}$ CBC News, "MPs Defeat Bid to Reopen Same-Sex Marriage Debate," CBC, December 7, 2006, https://www.cbc.ca/news/canada/mps-defeat-bid-to-reopen-same-sex-marriage-debate-1.599856.

382 Ibid.

${ }^{383}$ Gloria Galloway, "Same-Sex Marriage File Closed for Good, PM Says," The Globe and Mail, December 8, 2006, A1.

${ }^{384}$ Mia Rabson, "Scheer's Same-Sex Marriage Remarks Resurdace Amid Trudeau Scandal," Global News, September 20, 2019, https:/globalnews.ca/news/5927120/andrew-scheer-same-sex-marriage-redux/.
} 
legally closed in Canada, and the Conservative government would not reignite debate. ${ }^{385}$ In an interview with CTV's political program Question Period in November 2019, Stephen Harper's former director of communications, Kory Teneycke, commented that Scheer's stance on samesex marriage could threaten his current position; Teneycke stated, "Overwhelmingly Canadians do not accept that you can hold the position that 'I am not in favour of equal rights for gays and that I have a moral, a personal moral problem with gay marriage,' I think that is viewed increasingly as bigotry." 386

Teneycke's comments suggest that contemporary Canadian society has grown to become largely accepting and respectful of marriage equality; recent polls of Canadians' opinion on marriage equality validate this, indicating that the majority of Canadians are in support of samesex marriage. For instance, immediately following the US Supereme Court ruling in favour of same-sex marriage in 2015, Forum Research conducted a random sampling of Canadians' public opinion, determining that $70 \%$ of respondents approved same-sex marriage, while $22 \%$ disaaproved same-sex marriage and $8 \%$ did not having an opinion. ${ }^{387}$ In 2019 , Research Co. revealed the findings of a poll that examined Canadians' views on the legal recognition of samesex couples in the nation. Their findings show that $64 \%$ of Canadians believe same-sex couples should continue to be allowed to legally marry, while $15 \%$ believe same-sex couples should only be allowed to form civil unions and not marry, 10\% believe same-sex couples should not have any kind of legal recognition, and $11 \%$ were unsure. ${ }^{388}$ Given the results of past polls on public

\footnotetext{
${ }^{385}$ Rachel Aiello, "Sheer's Position on Same-Sex Marriage 'Could Be Fatal' Conservative Insiders Say," CTV News, November 1, 2019, https://www.ctvnews.ca/politics/scheer-s-position-on-same-sex-marriage-could-be-fatalconservative-insiders-say-1.4666444.

${ }^{386}$ Ibid.

${ }^{387}$ Lorne Bozinoff, "US Court Ruling Boosts Approval of Same Sex Marriage in Canada," Forum Research, July 3, 2015, http://staging-poll.forumresearch.com/post/307/increase-in-approval-seen-among-oldest/.

${ }^{388}$ Mario Canseco, "Almost Two Thirds of Canadians OK with Same-Sex Marriage," Research Co., August 1, 2019, https://researchco.ca/2019/08/01/i-want-the-world-to-know-got-to-let-it-show/.
} 
opinion, it comes to no surprise that support for marriage equality has reached such heights. Polls conducted by Ipsos-Reid between 1996 and 2004 reveal that support for same-sex marriage by Canadians has been known to fluctuate, but frequently surpassed 50\%; according to their polls, there was $49 \%$ approval of same-sex marriage in 1996, 55\% approval in 1999, 54\% approval in June 2003, 39\% in August 2003, and 54\% approval in October 2004. ${ }^{389}$

Given the aforementioned anecdotes, this dissertation provides some insight into why, nearly fifteen years after the legalization of same-sex marriage in Canada, there continues to be both a majority in support of marriage equality in the nation and no interest on the part of poltical parties to reverse legislation. That being said, it is imperative to take one final opportunity to review the dissertation's key findings, assert its conclusions, and make recommendations for future research.

Summary of Key Findings

Having arrived at the conclusion of this dissertation, we can now identify and summarize key findings that emerged throughout the chapters. First, it has been demonstrated that a definite shift transpired in terms of how the Canadian mainstream press treated the LGBTQ community and their issues. From refusing to acknowledge their existence until the 1960s, to sensationalizing and criminalizing them well until the 1980s, compassionate treatment towards queer Canadians by the national print media emerged amidst the HIV/AIDS crisis and efforts to pursue legislative changes. As Canadian mainstream newspapers began to acknowledge the legal, legislative, and health battles the Canadian LGBTQ community were publicly fighting, they began reporting on them with increased fairness, balance, and neutrality.

\footnotetext{
${ }^{389}$ Margaret Phillip, “Support For Same-Sex Marriage Still Split,” The Globe and Mail, October 7, 2004 , A4.
} 
Speaking specifically to the treatment of the legalization of same-sex marriage in Canada, both of the nation's national newspapers - The Globe and Mail and the National Post - covered the issue in their pages. Marriage equality's newsworthiness heightened upon the federal government's decision to legalize same-sex marriage across the country in June 2003 - a landmark decision that not only had a major effect on equality rights in the nation but ignited considerable political controversy and tension. Consistent with coverage patterns exhibited since the late-1980s, news stories about the legal fight for marriage equality in both papers were produced within known journalistic conventions of fairness and balance. That said, in both papers, opinion-based coverage slightly outweighed news-format coverage; audiences were presented with equal rights and traditional values frames - albeit to varying degrees - within this opinion-based coverage. The Globe and Mail had predominately equal rights frames, while the National Post had predominantly traditional values frames; however, the latter was more likely to include both perspectives than the former.

Finally, the history of gay activism in Canada is revealing of divergent attitudes towards marriage equality within the queer community. While the ideological divide between assimilationists and liberationists were never taken up by the national mainstream press, the Toronto-based gay publication Xtra! featured opinion pieces that reflected each position; however, the paper never editorialized their own stance. While The Body Politic, Xtra!'s predecessor, never addressed marriage equality - in part due to its liberationist stance - it can be suggested that, had they been in operation as the issue was taking off, the legalization of samesex marriage would be heavily critiqued. Furthermore, while the liberationist perspectives were omitted from the mainstream press, journalists' demonstrated a commitment to crafting balanced stories by reaching out to community members for their insights on phenomenon. The activists 
interviewed expressed that, when it came to dealing with the mainstream press, their perspectives were not distorted; that said, talk show interviews were more likely to be manipulated to cause tension amongst participants.

\section{Conclusions Drawn from the Research}

In light of the findings, it is possible to offer an explanation as to how and why the Canadian mainstream press shifted between anti-queer and pro-LGBTQ approaches to news items in a post-Charter Canada, and the effect this might have had on public opinion. One explanation for the respectable treatment of the legalization of same-sex marriage pertains to what the issue of marriage equality itself was all about: the right to be included. The fight for protection against discrimination, and subsequent efforts to achieve spousal benefits and family recognition signified to both journalists and the general public alike that the Canadian queer community simply wanted to be 'like everyone else'; evidence to support legal challenges stressed the white, middle-class, monogamous nature of these claimants and their desire to abide by heteronormativity, thus being nonthreatening to an institution perceived by many within the community as oppressive. This perspective, in conjunction with the increasing gains in LGBTQ rights in the nation, is suggested to have played a role in making not only the public, but also the national press, aware of the issue's importance; this in turn prompted the national print news media to treat the subject matter with more respect than they had historically. As has been discussed, LGBTQ-related issues were, for much of the twentieth century, largely ignored or heavily sensationalized by the Canadian mainstream press; indeed, one can postulate that, until the late-1980s, the Canadian LGBTQ community was relegated to the Sphere of Deviance. As LGBTQ rights recognition began to be fought in the courts and taken seriously by legislatures, suddenly, the matter gravitated to the Sphere of Legitimate Controversy, wherein these 
developments were not only acknowledged in print, but treated within journalistic conventions of fairness and balance.

The seriousness with which the Canadian legal system and, eventually, politicians, treated the legalization of same-sex marriage contributed to the national print media regarding this issue as one of significance that required professional coverage. Indeed, the Charter was utilized to challenge claims of discrimination and ultimately denounce the governance of marriage to be unconstitutional. Throughout the process, both activists and the courts framed the issue as one of equality rights - a frame that was picked up by journalists during reportage and incorporated within news stories. It was balanced in the press by the traditional rights frame one advanced by ideological opponents of marriage equality both within and outside the courts. As such, the framing picked up by the press revolved around these two opposing perspectives. Liberationist voices did not fit into these debating sides and were subsequently excluded both from legislative conversations and subsequent mainstream news stories; indeed, many within the queer community who were concerned with the institution of marriage feared that publicly denouncing it offered fuel for opponents.

Both frames circulated by way of both neutral reportage (by sharing the commentary of the subjects featured in the stories) and opinion-based coverage; when it came to opinion-based coverage, each national newspaper disseminated these frames, but featured them in varying quantities. The Globe and Mail emerged as a champion for equal rights, while the National Post maintained a desire for traditional mores to be upheld; while each paper prioritzed featuring opinion pieces that aligned with this position, an effort was made to include both. However, the National Post made a more conscious effort to minimize the disparity between both perspectives. 
As a result, while both readers would be exposed to each frame, readers of The Globe and Mail would be offered more supportive commentary.

How might this possibly effect readers' opinions? This dissertation has established that the relationship between media and publicness creates an environment hospitable to participation. The circulation of ideas through print, and their subsequent consumption, internalization, and discussion, allows individuals to establish where they position themselves ideologically when it comes to particular issues; it is then possible for them to base their acts of citizenship around this. Crucially, frames have the potential to impact this; while individuals have agency in arriving at their own conclusions, they often rely on media to provide common frames and reference. As the literature review has discussed, frames may be successful based on factors of mediation (i.e. their repetition, the degree to which there are competing frames, and an individual's own motivations) and moderators (i.e. individual predispositions, knowledge to understand and then be susceptible to frames, presentation, credibility, and availability). Indeed, those who may have had strong views one way or the other could've related to coverage mirroring their values coverage and resisted that which differed from their beliefs; that said, both papers ensured exposure to varying perspectives, thereby possibly influencing a reader to reflect on their stance. In this case, it would appear as though both papers offered fair and balanced news reports to give readers the capacity to make accurate decisions about their beliefs on the issues; however, each paper made their ideological positioning on the issue very clear, and while egalitarian and traditional views were featured, they were not evenly placed. This could have certainly affected the competition of frames, thereby giving a preferred frame a better chance of taking root with readers. One cannot ascertain whether public opinion was, in fact, affected by this, but one can theorize that the circulation of both neutral updates and differing opinions 
certainly contributed to their knowledge of the issue, awareness of varying perspectives, shaped any discussions they may have had with others.

\section{$\underline{\text { Recommendations for Future Research }}$}

Future research can address the limitations of the dissertation. First, the coding schedule could be expanded to also code for page placement (i.e. where the article was placed in the newspaper) as well as source (i.e. what sources were referenced in news coverage? This would involve identifying if official written documents, unofficial documents, official-speaking peoples or unofficial-speaking peoples were sourced). Taken together, the results of such coding would offer additional insight into how the Canadian national press prioritized the issue of marriage equality, and who and what were considered useful resources of information. Was marriage equality a front-page issue, or was it found deep within the paper? Who or what, specifically, were sources of information about marriage equality? How might this has shaped the construction of these stories?

In addition, as this research was conducted independently without the assistance of others, it was not possible for me to train coders to assist in the content analysis. As such, an intercoder reliability test, such as Cohen's Kappa, ${ }^{390}$ could not be completed. Analyses such as the one this dissertation has undertaken typically include a test of intercoder reliability based on a subset of the sample. This is done to not only facilitate the division of labour amongst multiple coders, but to control the accuracy of the coding; this is imperative as agreement amongst coders contributes to the overall quality of the research. Crucially, the findings based on my coding are still viable and valuable. Moreover, this dissertation serves as a foundation that other scholars

\footnotetext{
${ }^{390}$ Jacob Cohen, “A Coefficient of Agreement for Nominal Scales," Educational and Psychological Measurement 20, no. 1 (1960): 37-46.
} 
can build upon using multiple coders - whether that be through replicating this exact same study or adapting it to examine other phenomenon.

Furthermore, broadening the pool of interviewees could aid in increasing the validity of the results, as well as introduce additional insights that could be taken into consideration to help explain the phenomenon under investigation. To begin, all activists interviewed conducted much of their activism within Ontario; given that activist organizations were located throughout the nation, it would be useful to consider whether the experiences and perspectives of activists in other provinces would confirm the notions of the participants and/or provide alternative ideas. It would also be advantageous to speak with the lawyers who enthusiastically sought to deploy the Charter on behalf of lesbian and gay rights. How might their experiences with the media and outlooks differ from activists? On a similar note, interviewing those journalists who worked on Xtra! during the time period under investigation could give additional clarity into the editorial choices made by the paper with regards to marriage equality.

Moreover, future research could apply the same concept I've developed to a new context and location. While Canada was certainly an early adopter of marriage equality, it was not the first country to do so; in 2001, the Netherlands became the first country to legalize same-sex marriage, followed by Belgium in 2003 and Spain in 2005 - just weeks before Canada. To what extent did the national press of these three countries exhibit similar or different trends of reportage to that of their Canadian counterpart? Comparisons can be made closer to home as well; in what ways did the national mainstream press in two neighbouring countries - Canada and the United States - contribute to the legalization of same-sex marriage? Considering the tenyear gap between legislative changes in marriage equality, this would make for an intriguing point of departure. In addition, any attempts to adapt this study using a more recent case may 
wish to take into account the potential role of social media and filter bubbles. In what ways may audiences reinforce their own beliefs about same-sex marriage through the news channels they follow on social media? What are the consequences of being isolated in one's own ideological bubble on democracy generally and beliefs about same-sex marriage specifically? 


\section{Appendix A: Marriage Equality in Canada Timeline}

SEPTEMBER 1998

MARCH 2000

MAY 2000

AUGUST 2000

OCTOBER 2000

NOVEMBER 2000

DECEMBER 2000

JANUARY 2001

OCTOBER 2001

JULY 2002

SEPTEMBER 2002

MAY 2003

JUNE 2003
Couple Michael Hendricks and René LeBoeuf launch a legal challenge for the right to marry when they applied for a marriage license. They soon put it off.

Bill 202 is passed in Alberta, which orders that the notwithstanding clause will be used should a court redefine marriage to include samesex couples.

Martha McCarthy files a case in Ontario on behalf of seven couples seeking the right to marry (Halpern $v$. Canada).

The Hendricks and Leboeuf challenge relaunched with lawyers Anne-France Goldwater and Marie-Hélène Dubé.

Represented by lawyer Cynthia Petersen, Egale initiates legal proceedings in B.C., on behalf of itself and 5 same-sex couples (Egale v. Canada).

An additional three same-sex couples initiate separate legal proceedings in B.C., represented by lawyer barbara findlay (Barbeau v. British Columbia).

In Toronto, Reverend Brent Hawkes of the Metropolitan Community Church of Toronto (MCCT) reads the first banns for two same-sex couples.

After having read the banns on three Sundays before the wedding date, Reverend Hawkes marries two same-sex couples.

When the Ontario government refuses to register the two banns marriages, the MCCT launches an application, which is joined with the Halpern application.

B.C. Supreme Court rules against same-sex marriage.

The Ontario Superior Court rules in favor of same-sex marriage in light of the Halpern v. Canada case; denying gay couples the right to marry is deemed unconstitutional. The province is given two years to extend marriage rights. Shortly after, Ontario decides not to appeal the court ruling.

The Quebec Superior Court rules in favor of same-sex marriage in light of the Hendricks v. Quebec case Hendricks v. Quebec, with twoyear suspension.

The B.C. Superior Court rules in favour of same-sex marriage in light of Barbeau v. British Columbia, with a two-year suspension. Ontario Court of Appeal rules in favour of same-sex marriage, applying immediately. The federal swiftly announces upcoming legislation and Supreme Court references. 
JULY 2003

JANUARY 2004

MARCH 2004

JULY 2004

SEPTEMBER 2004

NOVEMBER 2004

DECEMBER 2004

FEBRUARY 2005

JUNE 2005

JULY 2005

DECEMBER 2006
The British Columbia Court of Appeal lifts its ban on same-sex marriages, giving couples in the province the right to marry immediately.

The federal government refers a draft bill to the Supreme Court, asking it to confirm its constitutionality by answering three questions before being put to a free vote in the House of Commons.

A fourth question is added to the original three questions sent to the Supreme Court for reference.

The Quebec Court of Appeal rules that gay couples have the right to marry.

Yukon Territory court rules in favour of same-sex marriage, which becomes effective immediately.

Manitoba and Nova Scotia courts rule in favour of same-sex marriages, which becomes effective immediately. Saskatchewan court rules in favour of same-sex marriage, which becomes immediately.

The Supreme Court of Canada rules that the federal government can change the definition of marriage to include same-sex couples.

Newfoundland and Labrador Supreme Court rules in favour of samesex marriage, which becomes effective immediately. The federal government's same-sex marriage bill (Bill C-38) is introduced in the House of Commons.

New Brunswick's Court of Queen's Bench rules in favour of samesex marriage, which becomes effective immediately.

Bill C-38 has its final reading in the House of Commons and is supported by way of a $158-133$ vote.

The Civil Marriage Act (Bill C-38) - the law giving same-sex couples the legal right to marry - receives royal assent and becomes law. The Conservative government brings in a motion asking to reopen the same-sex marriage debate; the motion is defeated in the House of Commons (175 against, 123 in support). 


\section{Appendix B: Dissertation Coding Schedule and Coding Protocol}

\section{Coding Schedule}

\begin{tabular}{|c|c|l|c|c|}
\hline $\begin{array}{c}\text { Case } \\
\#\end{array}$ & $\begin{array}{c}\text { Date of } \\
\text { Publication } \\
(\mathbf{d d} / \mathbf{m m} / \mathbf{y y})\end{array}$ & Newspaper & $\begin{array}{c}\text { Article } \\
\text { Type }\end{array}$ & $\begin{array}{c}\text { Framing } \\
\text { Type }\end{array}$ \\
\hline 1 & & & & \\
\hline 2 & & & & \\
\hline 3 & & & & \\
\hline 4 & & & & \\
\hline
\end{tabular}

Coding Analysis Protocol

\section{Selection Criteria}

- The article must have been published between April $17^{\text {th }}, 1982$ and July $20^{\text {th }}, 2005$

- The article must be self-written and not an exported story from newswires

- In an attempt to cover the breadth of media coverage, all article types will be considered

\section{Analytical Categories}

1. Category title: "Date of Publication"

Label: Date article was published

Code: Written

2. Category title: "Newspaper"

Label: The name of the newspaper the article was published in

Code: Written

3. Category title: "Article Type"

Label: The type of newspaper article the unit is

Values/definitions:

\begin{tabular}{|l|l|}
\hline 001: News Report & $\begin{array}{l}\text { Located at the front of a newspaper, news } \\
\text { reports inform readers about local and world } \\
\text { events. }\end{array}$ \\
\hline 002: Editorial & $\begin{array}{l}\text { Written by the senior editorial staff of a } \\
\text { newspaper; often unsigned. } \\
\text { From Harrower: "Commentary that expresses } \\
\text { opinion about a current event or issue (usually } \\
\text { the opinion of an editor, publisher, or owner); } \\
\text { the department of the newspaper that gathers, } \\
\text { writes, editors, and publishes news" (322) }\end{array}$ \\
\hline
\end{tabular}




\begin{tabular}{|l|l|}
\hline 003: Letter to the Editor & $\begin{array}{l}\text { A letter sent to a publication about issues of } \\
\text { concern from its readers. }\end{array}$ \\
\hline 004: Column & $\begin{array}{l}\text { A piece where a writer expresses their own } \\
\text { opinion in few columns allotted to them by } \\
\text { the newspaper organization. Columns are } \\
\text { written by columnists. What differentiates a } \\
\text { column from other forms of journalism is that } \\
\text { it is a regular feature in a publication - written } \\
\text { by the same writer or reporter and usually on } \\
\text { the same subject area or theme each time }- \\
\text { and that it typically, but not universally, } \\
\text { contains the author's opinion or point of view. }\end{array}$ \\
\hline $005:$ Op-Ed & $\begin{array}{l}\text { A written prose piece which expresses the } \\
\text { opinion of a named author usually not } \\
\text { affiliated with the publication's editorial } \\
\text { board. }\end{array}$ \\
\hline $006:$ Feature Article & $\begin{array}{l}\text { Pieces that explore news stories in more } \\
\text { depth. They may be triggered by a story that } \\
\text { has been in the news for a while. The purpose } \\
\text { of a feature is not just to tell you what has } \\
\text { happened, but to explore or analyze the } \\
\text { reasons why. }\end{array}$ \\
\hline $007:$ Other & $\begin{array}{l}\text { Could be in comment section, a personal } \\
\text { essay, in facts and arguments section, a joke. }\end{array}$ \\
\hline
\end{tabular}

4. Category Title: "Framing Type"

Label: How were articles framed? Frames tell audiences what an issue is about, and communicators seek to establish the dominance of their frame.

\begin{tabular}{|l|l|}
\hline 001: Equal rights frame & $\begin{array}{l}\text { The equal rights frame is generally used to } \\
\text { argue in favor of same-sex marriage on } \\
\text { the basis of equal rights for all. It } \\
\text { encompasses a broad range of discussion } \\
\text { about rights, discrimination, fairness, and } \\
\text { specific benefits that are afforded to } \\
\text { married couples. Articles that emphasize } \\
\text { the rights being denied to gay and lesbian } \\
\text { couples are also coded as containing an } \\
\text { equal rights frame. }\end{array}$ \\
\hline $002:$ Traditional values frame & $\begin{array}{l}\text { The traditional values frame is used to } \\
\text { argue against same-sex marriage on the } \\
\text { grounds of traditional moral values. It } \\
\text { encompasses a wide array of arguments } \\
\text { against same-sex marriage, including }\end{array}$ \\
\hline
\end{tabular}




\begin{tabular}{|c|c|}
\hline & $\begin{array}{l}\text { arguments featuring religious and biblical } \\
\text { elements, threats to the family structure, } \\
\text { and threats to our traditionally held } \\
\text { morals. }\end{array}$ \\
\hline 003: Both & $\begin{array}{l}\text { The equal rights and the traditional values } \\
\text { frames can appear in the same article. At } \\
\text { times one frame is accepted and another } \\
\text { rejected, and at times both frames are } \\
\text { presented without the article or author } \\
\text { favoring one or the other. The latter } \\
\text { situation is common when journalists } \\
\text { present arguments from both sides of an } \\
\text { argument. One frame is often accepted } \\
\text { while another is rejected in editorials or } \\
\text { columns that clearly have a strong opinion } \\
\text { about same-sex marriage or articles that } \\
\text { feature an interest group evoking their } \\
\text { opponents' argument in the course of } \\
\text { discrediting it. }\end{array}$ \\
\hline 004: Neutral & $\begin{array}{l}\text { A neutral or objective frame relays to the } \\
\text { audience the ideas that the subjects (that } \\
\text { is, the people the story is about) are } \\
\text { putting forward, as they intend those ideas } \\
\text { to be understood. A neutral news frame } \\
\text { will place events in perspective by } \\
\text { providing relevant background and will } \\
\text { allow those who are criticized in the body } \\
\text { of the report to respond fully to the } \\
\text { accusations of their critics. }\end{array}$ \\
\hline
\end{tabular}




\section{Appendix C: Interview Guide}

The semi-structured interviews for journalists will touch on the following themes:

- Opening

○ Preamble: explanation of project

- Ethics

- The process of developing frames in the newsroom

- Make sure participants have an understanding of what framing is and its implications for the reception of news stories

- Referring to your own experience, can you describe the process of developing frames for news stories?

- Frames used to discuss the legalization of same-sex marriage in Canada

- Referring to your own experience, can you tell me about how your papers' frames towards same-sex marriage were decided upon? Why was this the case?

- The creation of stories regarding the legalization of same-sex marriage in Canada

- In the process of actually creating the stories, what facts or evidence did you decide to include or emphasize? What sources did you choose to consult? What was the issue at stake?

- Ending

- Any questions not asked?

- Any questions for researcher?

- Recommendations of acquaintances who might qualify for participation?

The semi-structured interviews for activists will touch on the following themes:

- Opening

○ Preamble: explanation of project

$\circ$ Ethics

- Learning about participant's background (i.e. were/are they an activist, lobbyist, key player)

- General discussion of framing in news story-telling

- Make sure participants have an understanding of what framing is and its implications for the reception of news stories

- Given what you understand about frames, and based on your own experiences, can speak to times when media frames were very obvious? How did it make you feel? Did you feel your perspective shift?

- What impact do you feel framing can have on perceptions of social movements? Can you give any examples? (can also offer articles to prompt)

- Specific discussion on framing of the legalization of same-sex marriage in Canada

- Do you recall the types of news stories that would exist in mainstream Canadian newspapers? Alternative papers? Can you recall how they framed the story? How might these stories have implicated your understanding of the issue? How might it have implicated your level of support?

- Participation in the construction of news stories re: the legalization of same-sex marriage in Canada 
- Were you consulted by a news reporter as part of their research for a news story on the legalization of same-sex marriage? Why did you choose or refuse to participate? What was the outlet? How were you initially approached? Did you have an opportunity to prepare? What did you wish to say? Were you briefed on their objectives with the article? Do you recall the questions you were asked? What were your thoughts on the finished product? Do you feel your perspectives was reported

- Ending accurately? How do you feel about your contribution?

- Any questions not asked?

- Any questions for researcher?

○ Recommendations of acquaintances who might qualify for participation? 


\section{Reference List}

\section{$\underline{\text { Primary Sources }}$}

Barker, Kate. "Let's Call the Whole Thing Off: The Debate Over Gay Marriage Splits the Community in Two." Xtra!, March 26, 1998, 23.

Brown, Eleanor. "The Kiss.” Xtra!, January 25, 2001, 9.

Canadian Press. "Homosexual Pair Become Partners in Public, Private." The Globe and Mail, February 28, 1972, 9.

Cohen, Nathan. “Monday Miscellany.” Toronto Daily Star, night ed., January 13, 1964, 18.

Constitution Act, 1982. https://laws-lois.justice.gc.ca/eng/const/page-15.html.

Cossman, Brenda. “The Full Monty: Spousal Rights Means You'll Be On the Hook For Years to Come.” Xtra!, April 8, 1999, 11.

Cossman, Brenda. "No Sex, Please: National Lobby Group Stands Up For Respectable Rights Only.” Xtra!, February 25, 1999, 11.

Dorge, Michel. “Memo To: Newlyweds.” Xtra!, January 25, 2001, 11.

Egan, Jim. Challenging the Conspiracy of Silence: My Life As a Canadian Gay Activist. Edited by Donald W. McLeod. Toronto: Canadian Lesbian and Gay Archives, 1998.

Gallant, Paul. "Aunt Frances Waits With Bated Breath: Lessons Learned From Parliament's Marriage Debate.” Xtra!, March 30, 2005. https://www.dailyxtra.com/aunt-frances-waitswith-bated-breath-39876.

Gershbain, Nikki. "Waiting At the Altar: We Need Queer Ways to Celebrate Our Relationships \& Create Rituals.” Xtra!, May 22, 1997, 37.

Gulliver, Tanya. “Customize Your Love: Queer Marriages Aren’t Paint By Numbers.” Xtra!, October 30, 2003, 14.

Gulliver, Tanya. "Hitching \& Shacking: A Homo’s Guide to Marriage Versus Common Law." Xtra!, September 4, 2003, 10-11.

Gulliver, Tanya. “Marriage Timeline,” Xtra!, October 13, 2004. https://www.dailyxtra.com/marriage-timeline-40820.

Gulliver, Tanya and Paul Gallant. "Are We Stupid \& Squeaky? Marriage Could Be One Right Too Many?” Xtra!, October 01, 2003. https://www.dailyxtra.com/are-we-stupid-squeaky43174 
Gulliver, Tanya and Krishna Rau. "How Does It Feel? The Meaning of the Marriage Vote for the Movement.” Xtra!, July 5, 2005, 13.

Hanlon, Michael. "Homosexual Clubs Worry Metro Police." The Globe and Mail, August 5 $1964,8$.

Hansard Transcript. "Speech by Prime Minister Paul Martin: The Civil Marriage Act.” Xtra!, February 15, 2005. https://www.dailyxtra.com/speech-by-prime-minister-paul-martin39400.

House of Commons of Canada. "The Text of the Same-Sex Marriage Bill: Here's What the Bill Says... and Doesn't Say.” Xtra!, February 16, 2005. https://www.dailyxtra.com/the-textof-the-same-sex-marriage-bill-39401.

Hoy, Claire. "Homosexuals Far from Harmless.” Toronto Sun, May 18, 1978, 34.

Jackson, Ed and Stan Persky. Flaunting It!: A Decade of Gay Journalism From the Body Politic: An Anthology. Vancouver: New Star Books, 1982.

Katz. Sidney. "The Harsh Facts of Life in the 'Gay' World." Maclean's, March 7, 1964, 18, 34-38

Katz, Sidney. "The Homosexual Next Door: A Sober Appraisal of a New Social Phenomenon." Maclean's, February 22, 1964, 10-11, 28-30.

Katz, Sidney. "What Should I Do?: Does Discussing Homosexuality Encourage It?”(column). Toronto Daily Star, September 15, 1966, 3.

Katz, Sidney. "What Should I Do?: How Can I Tell If My Son, 12, Is Homosexual?" Toronto Daily Star, September 17, 1966, 3.

Kirkby, Gareth. "Egale Blows It: Didn’t Live Up to Promise on Bill C-2.” Xtra!, June 27, 2005, https://www.dailyxtra.com/egale-blows-it-39352.

Kirkby, Gareth. "The Right to Be Wrong: Religious People Have Right to Speak Out.” Xtra!, October 1, 2003. https://www.dailyxtra.com/the-right-to-be-wrong-43145.

Lewandowski, Andrea. "Marriage 101: Learn Your Way Around Common Law Before You Tie the Knot.”Xtra!, August 13, 2003. https://www.dailyxtra.com/marriage-101-43447.

McCreary, J.K., "Psychopathia Homosexualis." Canadian Journal of Psychology 2, 2 (1950): 63-74.

Mackenzie, Ian. "Equal, Equal, Equal, Equal: How Do You Tell The Marriage Groups Apart?" Xtra!, December 10, 2003. https://www.dailyxtra.com/equal-equal-equal-equal-42732. 
Maloney Leonard, Michelle. “Why Just Two Spouses?” Xtra!, June 26, 2003, 7-8.

Munter, Alex. "Gay Marriage Rights: The Canadian Thing to Do.” Xtra!, June 29, 2005, https://www.dailyxtra.com/gay-marriage-rights-the-canadian-thing-to-do-39350.

Nicholls, William. "Homosexuality: Changing the Laws Could Raise Morality." Vancouver Sun, four star ed., 6 July 1965, 6.

Poulton, Ron. "Church and Law" (part 3). Toronto Telegram, April 15, 1964, 7.

Poulton, Ron. "The Sick Life” (part 2). Toronto Telegram, April 14, 1964, 7.

Poulton, Ron. "Society and the Homosexual" (part1). Toronto Telegram, April 11, 1964, 7.

Sinopoli, John. "To Court, To Court: Our Guide to All These Marriage Challenges." Xtra!, October 31, 2001. https://www.dailyxtra.com/to-court-to-court-45902.

Spencer, William. "Canada's Leading Homosexual Speaks Out." Weekend Magazine, September 13, 1969.

Standing Senate Committee on Transport and Communications. Final Report on the Canadian News Media. Volume 1, June 2006.

Tibbetts, Janice. "MPs Vote to Drop Appeal of Same-Sex Ruling." National Post, 13 June 2003, A7.

Totzkey, Michael. "Cause For a (Small) Celebration.” The Body Politic, September 1985, 15 \& 17.

Unknown. "News of the Gay." The Body Politic, March/April 1972, 9.

Unsigned Editorial. "Minorities Have Civil Rights as Well”. Toronto Star, Saturday ed., May 20, 1978, C2.

Unsigned Editorial. "Homosexuals: Where the Star Draws the Line." Toronto Star, Saturday ed., October 19, 1974, B2.

Unsigned Editorial. No Title. The Body Politic, May/June 1972, 2.

Vallis, Mary. "Getting Cold Feet: The Right to Wed is Creating Fresh Tensions for Many Gay Couples." National Post, 28 June 2003, A1.

Warner, Tom. "Simply Yes, Yes, Yes \& No? What the Supreme Court Should Have Said." Xtra!, December 8, 2004. https://www.dailyxtra.com/simply-yes-yes-yes-no-40464. 
Warner, Tom. "Story of a Same-Sex Spousal Rights Strategy: Bandwagon Effect \& Media Attention Narrowed the Focus of the Campaign.” Xtra!, June 5, 1997, 28.

Webster, Norman. "Hot Topic Coolly Handled." The Globe and Mail, May 18, 1978, 7.

Wilson, Renate. "What Turns Women to Lesbianism?" Chatelaine, October 1966, 33, 130-32, 134.

Zaslofski, Lee. "Housing: A Family Affair.” The Body Politic, October 1985, 17. 


\section{$\underline{\text { Secondary Sources }}$}

\section{Newspapers}

Aiello, Rachel. "Sheer's Position on Same-Sex Marriage 'Could Be Fatal' Conservative Insiders Say." CTV News, November 1, 2019. https://www.ctvnews.ca/politics/scheer-s-positionon-same-sex-marriage-could-be-fatal-conservative-insiders-say-1.4666444.

CBC Archives. "The Birth of the National Post and 'the Impending Newspaper War'." CBC, October 27, 2018. https://www.cbc.ca/archives/the-birth-of-the-national-post-and-theimpending-newspaper-war-1.4875372.

CBC News. "BCE Gets Green Light: Bell Globemedia born.” $C B C$. January 9, 2001, https://www.cbc.ca/news/business/bce-gets-green-light-bell-globemedia-born-1.278218.

CBC News. "Chris Vogel, Richard North fight for Manitoba to recognize 41-year same-sex Marriage.” $C B C$, February 18, 2018. https://www.cbc.ca/news/canada/manitoba/chrisvogel-richard-north-fight-for-manitoba-to-recognize-41-year-same-sex-marriage1.2961152 .

CBC News. "MPs Defeat Bid to Reopen Same-Sex Marriage Debate." $C B C$, December 7, 2006. https://www.cbc.ca/news/canada/mps-defeat-bid-to-reopen-same-sex-marriage-debate1.599856 .

CBC News. "Same-sex Winnipeg couple won't quit fight to have 1974 marriage recognized." $C B C$, February 15, 2018. https://www.cbc.ca/news/canada/manitoba/same-sex-winnipegcouple-won-t-quit-fight-to-have-1974-marriage-recognized-1.4537406.

Dacey, Elisha. "Failing to register 1974 same-sex marriage not discriminatory: Manitoba human rights adjudicator." $C B C$, January 10, 2018.

https://www.cbc.ca/news/canada/manitoba/failing-register-1974-same-sex-marriage-notdiscriminatory-1.4480879.

Galloway, Gloria and Brian Laghi. "Harper Reopens Same-Sex Debate.” The Globe and Mail, November 30, 2005, A1.

Galloway, Gloria. "Same-Sex Marriage File Closed for Good, PM Says." The Globe and Mail, December 8, 2006, A1.

Frum, Barbara. “Gay Winnipeg Couple Marries.” As It Happens, February 21, 1974. https://www.cbc.ca/archives/entry/gay-winnipeg-couple-marries.

Kennedy, John. "Pride in Our Press: Toronto’s History of Gay Publications." fab, June 10-23, 1999, 24. 
Lenti, Erica et al., "All the ways Canada is still screwing over LGBTQ2 people.” Xtra, June 28, 2019. https://www.dailyxtra.com/all-the-ways-canada-is-still-screwing-over-lgbtq2people-158779.

Nagy, Sasha. "Mass Media." The Globe and Mail. July 13, 2006. https://www.theglobeandmail.com/opinion/mass-media/article24356794/.

Nicol, Nancy. "Interview with Chris Vogel and Richard North (2004), as they discuss their marriage in 1974." The ArQuives, accessed November 18, 2018, https://vimeo.com/193923100.

Phillip, Margaret. "Support For Same-Sex Marriage Still Split." The Globe and Mail, October 7, 2004, A4.

Rabson, Mia. "Scheer's Same-Sex Marriage Remarks Resurdace Amid Trudeau Scandal." Global News, September 20, 2019. https://globalnews.ca/news/5927120/andrew-scheersame-sex-marriage-redux/.

Reuters. "Thomson family's Woodbridge buys full control of Globe and Mail." $C B C$, August 14, 2015. https://ca.reuters.com/article/businessNews/idCAKCN0QJ2AJ20150814.

Rider, David. "Gay Newspaper Xtra to Stop Printing, Go Digital Only.” Toronto Star, January 14, 2015, https://www.thestar.com/entertainment/2015/01/14/gay-newspaper-xtra-tostop-printing-go-digital-only.html.

The Canadian Press. "Postmedia Network Acquires Canwest's Newspaper Division." CTV, July 14, 2010. https://www.ctvnews.ca/postmedia-network-acquires-canwest-s-newspaperdivision-1.532616. 


\section{Literature}

Accountable Journalism. "Canada: Canadian Association of Journalists Principals for Ethical Journalism.” Accountable Journalism. Accessed May 23 ${ }^{\text {rd }}, 2019$. https://accountablejournalism.org/ethics-codes/Canada-CAJ-Principles.

Adams, Mary Louise. The Trouble With Normal: Postwar Youth and the Making of Heterosexuality. Toronto: University of Toronto Press, 1997.

Allen, Gene. Making National News: A History of Canadian Press. University of Toronto Press, 2013.

Anderson, Benedict. Imagined Communities: Reflections on the Origin and Spread of Nationalism. New York: Verso, 2006.

Arendt, Hannah. The Human Condition. $2^{\text {nd }}$ ed. Chicago: University of Chicago Press, 1998.

Atton, Chris. Alternative Media. Thousand Oaks: SAGE Publications, 2002.

Baker, C. Edwin. Media, Markets, and Democracy. Cambridge, MA: Cambridge University Press.

Baker, C. Edwin. "Media Structure, Ownership Policy, and the First Amendment," Southern California Law Review 78 (2005): 733-762.

Bannerman, Sara. "Same-Sex Marriage, Social Cohesion, and Canadian Values: A Media Analysis." Canadian Journal of Communication 36, no. 4 (2012): 599-617.

Barker, David C. "Values, Frames, and Persuasion in Presidential Nomination Campaigns." Political Behavior 27, no. 4 (2005): 375-394

Berlant, Lauren. Cruel Optimism. Durham: Duke University Press, 2011.

Bolen, Derek M. "Homonormativity." In The SAGE Encyclopedia of LGBTQ Studies, edited by Abbie E. Goldberg, 542-544. Thousand Oaks, CA: SAGE Publications, 2016.

Bradburn, Jamie. "Historicist: I Sing The Body Politic.” Torontoist. February 14, 2005. https://torontoist.com/2015/02/historicist-i-sing-the-body-politic/.

Brewer, Paul. "Framing, Value Words, and Citizens' Explanations of their Issue Opinions," Political Communication 19, no. 3 (2002): 303-316.

Brewer, Paul. "The Shifting Foundations of Public Opinion About Gay Rights." The Journal of Politics 65, no. 4 (2003): 1208-1220. 
Brewer, Paul. "Values, Political Knowledge and Public Opinion about Gay Rights:

A Framing-based Account." Public Opinion Quarterly 67, no. 2 (2003): 173-201.

Brewer, Paul. "Value Words and Lizard Brains: Do Citizens Deliberate About Appeals to their Core Values?," Political Psychology 22, no. 1 (2001): 45-64

Brouwer, Daniel C. "Communication as Counterpublic." In Communication As...Perspectives on Theory, edited by Gregory J. Shepherd, Jeffrey St. John, and Ted Striphas, 195-208. Thousand Oaks, Calif.: Sage Publications, 2006.

Brown, Michael P. Replacing Citizenship: AIDS Activism and Radical Democracy. New York Press, Guilford Press, 1997.

Campbell, Kathryn. “'Deviance, Inversion and Unnatural Love:' Lesbians in Canadian Media, 1950-1970." Atlantis 23, no. 1 (1998): 128-136.

Carey, James. Communication as Culture: Essays on Media and Society. Boston: Unwin Hyman, 1989.

Chenier, Elise. "Liberating Marriage: Gay Liberation and Same-Sex Marriage in Early 1970s Canada." In We Still Demand! Redefining Resistance in Sex and Gender Struggles, edited by Patrizia Gentile, Gary Kinsman, and L. Pauline Rankin, 29-51. Vancouver: UBC Press, 2017.

Chenier, Elise. Strangers in Our Midst: Sexual Deviance in Postwar Ontario. Toronto: University of Toronto Press, 2008.

Chong, Dennis. Rational Lives: Norms and Values in Politics and Society. Chicago: University of Chicago Press, 2000.

Chong, Dennis and James N. Druckman. "Framing Theory.” Annu. Rev. Polit. Sci. 10 (2007): 103-126.

Churchill, David Stewart. "Coming out in a Cold Climate: A History of Gay Men in Toronto During the 1950s." MA thesis, University of Toronto, 1993.

Cohen, Jacob. "A Coefficient of Agreement for Nominal Scales." Educational and Psychological Measurement 20, no. 1 (1960): 37-46.

Crossley, Nick and John Michael Roberts, eds., After Habermas: New Perspectives on the Public Sphere. Malden, MA: Blackwell Publishing, 2004.

Curran, James. "Rethinking the Media as a Public Sphere." In Communication and Citizenship: Journalism and the Public Sphere in the New Media Age, edited by Peter Dahlgren and Colin Sparks, 27- 57. New York: Routledge, 1991. 
Dahlgren, Peter. Television and the Public Sphere. Thousand Oaks, Calif.: Sage Publications, 1995.

Deuze, Mark. "What Is Journalism? Professional Identity and Ideology of Journalists Reconsidered." Journalism 6, no. 4 (2005): 442-464.

Dewey, John. The Public and Its Problems. Athens, Ohio: Swallow Press/Ohio University Press, 1991.

Druckman, James N. "On the Limits of Framing Effects: Who Can Frame?" Journal of Politics 63, no. 4 (2001): 1041-1066.

Duder, Cameron. Awfully Devoted Women: Lesbian Lives in Canada, 1900-65. Vancouver, British Columbia: UBC Press, 2010.

Dugan, Lisa. "The New Homonormativity: The Sexual Politics of Neoliberalism.” In Materializing Democracy: Toward a Revitalized Cultural Politics, edited by Russ Castronovo, Dana D. Nelson, 175-194. Durham, NC: Duke University Pres, 2002.

Duggan, Lisa. The Twilight of Equality?: Neoliberalism, Cultural Politics, and the Attack on Democracy. Boston: Beacon Press, 2012.

Entman, Robert M. "Framing: Toward Clarification of a Fractured Paradigm." Journal of Communication 43, no. 4 (1993): 51-58.

Entman, Robert M., et al. "Nature, Sources, and Effects of News Framing." In The Handbook of Journalism Studies, edited by Karin Wahl-Jorgensen and Thomas Hanitzsch, 175-190. New York: Routledge, 2009.

Eskridge, William N. "The Same-Sex-Marriage Debate and Three Conceptions of Equality.” In Marriage and Same-Sex Unions: A Debate, edited by Lynn D. Wardle et al., 167-185. Westport, CT: Praeger Publishers, 2003.

Fraser, Nancy. "Rethinking the Public Sphere: A Contribution to the Critique of Actually Existing Democracy." In Habermas and the Public Sphere, edited by Craig Calhoun, 109-142. Cambridge, Mass.: MIT Press, 1989.

Fuchs, Christian. Foundations of Critical Media and Information Studies. New York: Routledge, 2011.

Fung, Richard, and Tim McCaskell. "Continental Drift: The Imaging of AIDS.” In Queerly Canadian: An Introduction Reader in Sexuality Studies, edited by Maureen FitzGerald and Scott Rayter, 191-196. Toronto, Ontario: Canadian Scholars' Press Inc., 2012. 
Gamson, William A. and Andre Modigliani. "Media Discourse and Public Opinion on Nuclear Power: A Constructionist Approach.” American Journal of Sociology 95, no. 1 (1989): 137.

Galtung, Johan and Mari Holmboe Ruge. "The Structure of Foreign News the Presentation of the Congo, Cuba and Cyprus Crises in Four Norwegian Newspapers.” Journal of Peace Research 2, no. 1 (1965): 64-90.

Gentile, Patrizia, Gary Kinsman, and L. Pauline Rankin, eds. We Still Demand!: Redefining Resistance in Sex and Gender Struggles. UBC Press, 2016.

Gillespie, Bruce. News Writing and Reporting: An Introduction to Skills and Theory. Don Mills, Ontario: Oxford University Press, 2018.

Gitlin, Todd. The Whole World is Watching: Mass Media in the Making \& Unmaking of the New Left. Berkeley : University of California Press, 1980.

Gleason, Mona. "Psychology and the Construction of the 'Normal' Family in Postwar Canada, 1945-1960." The Canadian Historical Review 78, no. 3 (1997): 442-477.

Gorman, Brian. Crash to Paywall: Canadian Newspapers and the Great Disruption. Kingston: McGill-Queen's University Press, 2015.

Griffin, Penny. "Sexing the Economy in a Neo-Liberal World Order: Neo-Liberal Discourse and the (Re) Production of Heteronormative Heterosexuality." The British Journal of Politics and International Relations 9, no. 2 (2007): 220-238.

Gripsrud Iostein et al., "Editors Introduction.” In The Idea of the Public Sphere: A Reader, edited by Iostein Gripsrud et al., xxxi-xxviii. Lanham, Maryland: Lexington Books, 2010.

Grube, John. "Natives and Settlers: An Ethnographic Note on Early Interaction of Older Homosexual Men With Younger Gay Liberationists." Journal of Homosexuality 20, no. 3-4 (1991): 119-135.

Habermas, Jürgen. “The Public Sphere.” In Contemporary Political Philosophy: An Anthology, edited by Robert E. Goodin and Phillip Petit, 103-107. Oxford: Blackwell Publishers 1997.

Habermas, Jürgen. The Structural Transformation of the Public Sphere: An Inquiry Into a Category of Bourgeois Society. Translated by Thomas Burger. Cambridge, Mass.: MIT Press, 1989.

Hallin, Daniel C. The "Uncensored War": The Media and Vietnam. New York: Oxford University Press, 1986. 
Hallin Daniel C. and Paolo Mancini. Comparing Media Systems: Three Models of Media and Politics. New York: Cambridge University Press, 2004.

Hansen, Anders and David Machin. Media and Communication Research Methods. London, UK: Palgrave Macmillan, 2013.

Harcup, Tony and Deirdre O'Neill. "What Is News? Galtung and Ruge Revisited." Journalism Studies 2, no. 2 (2001): 261-280.

Harrower, Tim. Inside Reporting: A Practical Guide to the Craft of Journalism, $6^{\text {th }}$ ed. New York: McGraw-Hill, 2010.

Hartley, John. The Politics of Pictures: The Creation of the Public in the Age of Popular Media. New York: Routledge, 1992.

Hill, Mike and Warren Montag, eds. Masses, Classes, and the Public Sphere. New York, N.Y.: Verso, 2000.

Hegel, Georg Wilhelm Friedrich. Philosophy of Right. Trans. S.W. Dyde. Amherst, New York: Prometheus Books, 1996.

Hogg, Peter W. "Canada: the Constitution and Same-Sex Marriage.” International Journal Constitutional Law 4 no. 4 (2006): 712-721.

Iyengar, Shanto. Is Anyone Responsible?: How Television Frames Political Issues. Chicago: University of Chicago Press, 1991.

Iyengar, Shanto. "Television news and citizens' explanations of national affairs." American Political Science Review 81, no. 3 (1987): 815-831

Jim Loves Jack: The James Egan Story. Produced by David Adkin Productions, in association with Vision TV and the Knowledge Network. 53 minutes. 1995. DVD.

Kant, Immanuel. “An Answer to the Question: What is Enlightenment?" In Practical Philosophy. Translated and edited by Mary J. Gregor, 11-22. New York: Cambridge University Press, 1996.

Kinsman, Gary. The Regulation of Desire: Homo and Hetero Sexualities. Montréal: Black Rose Books, 1996.

Kinsman, Gary and Patrizia Gentile. The Canadian War on Homosexuals: National Security as Sexual Regulation. Vancouver, British Columbia: UBC Press, 2010.

Knegt, Peter. About Canada: Homosexual Rights. Halifax: Fernwood Pub., 2011. 
Kovach, Bill and Tom Rosenstiel. The Elements of Journalism: What Newspeople Should Know and the Public Should Expect. New York: Three Rivers Press, 2014.

Lahey, Kathleen. Are We 'Persons' Yet: Law and Sexuality in Canada. Toronto, University of Toronto Press, 1999.

Li, Xigen, and Xudong Liu. "Framing and Coverage of Same-Sex Marriage in US Newspapers." The Howard Journal of Communications 21, no. 1 (2010): 72-91.

Liebler, Carol M., Joseph Schwartz, and Todd Harper. "Queer Tales of Morality: The Press, Same-Sex Marriage, and Hegemonic Framing." Journal of Communication 59, no. 4 (2009): 653-675.

Lippmann, Walter. Public Opinion. Toronto: Free Press Paperbacks, 1997.

Livingstone, Sonia. "On the Relations Between Audiences and Publics.” In Audiences and Publics: When Cultural Engagement Matters for the Public Sphere, edited by Sonia Livingstone, 17-42. Portland, Or.: Intellect, 2005.

Livingstone, Sonia and Peter Lunt. Talk on Television: Audience Participation and Public Debate. London: Routledge, 1994.

MacDougall, Bruce. Queer Judgments: Homosexuality, Expression and the Courts in Canada. Toronto: University of Toronto Press, 2000.

Matthews, J. Scott. "The Political Foundations of Support for Same-Sex Marriage in Canada." Canadian Journal of Political Science 38, no. 4 (2005): 841-866.

McCaskell, Tim. Queer Progress: From Homophobia to Homonationalism. Toronto: Between the Lines, 2016.

McLeod, Donald W. A Brief History Of GAY, Canada's First Gay Tabloid, 1964-1966. Toronto: Homewood Books, 2003.

McCleod, Donald W. Lesbian and Gay Liberation in Canada: a Selected Annotated Chronology, 1964-1975. Toronto: ECW Press/Homewood Books, 1996.

McCleod, Donald W. Lesbian and Gay Liberation in Canada: a Selected Annotated Chronology, 1964-1975. Toronto: ECW Press/Homewood Books, 2017.

McCombs, Maxwell et al, The News and Public Opinion: Media Effects on Civic Life Cambridge: Polity Press, 2011.

McKee, Alan. The Public Sphere: An Introduction. New York, NY: Cambridge University Press, 2005. 
McKeon, Lauren. "A Guide, Not a Cop: the CAJ's New Ethics "Code" (And Why It's Not Called That)." Accessed May 25 ${ }^{\text {th }}, 2019$. https://j-source.ca/article/a-guide-not-a-cop-thecajs-new-ethics-code-and-why-its-not-called-that/.

Mill, John Stuart. "Of the Liberty of Thought and Discussion." On Liberty. Edited by Edward Alexander. Peterborough, Ont.: Broadview Press, 1999.

Morley, David. "Industrial Conflict and the Mass Media." The Sociological Review 24, no. 2 (1976): 245-268.

Mulé, Nick J. "Same-sex marriage and Canadian relationship recognition-One step forward, two steps back: A critical liberationist perspective." Journal of Gay \& Lesbian Social Services 22, no. 1-2 (2010): 74-90.

Muñoz, José Esteban. Cruising Utopia: The Then and There of Queer Futurity. New York: New York University Press, 2009.

Nelson, Thomas E., Rosalee A. Clawson, and Zoe M. Oxley, "Media Framing of a Civil Liberties Conflict and its Effect on Tolerance." American Political Science Review 91, no. 3 (1997): 567-583.

Norris, Pippa et al. "Introduction." In Framing Terrorism: The News Media, the Government and the Public, edited by Pippa Norris et al, 3-23. New York: Routledge, 2003.

Organization for Security and Co-operation in Europe (OSCE). The Media Self-Regulation Guidebook. Office of the Representative on Freedom of the Media, 2008.

Pan, Po-Lin, Juan Meng, and Shuhua Zhou. "Morality or Equality? Ideological Framing in News Coverage of Gay Marriage Legitimization." The Social Science Journal 47, no. 4 (2010): 630-645.

Pan, Zhongdang and Gerald M. Kosicki. "Framing Analysis: An Approach to News Discourse," Political Communication 10, no. 1 (1993): 55-75.

Pettinicchio, David. "Public and Elite Policy Preferences: Gay Marriage in Canada." International Journal of Canadian Studies, no. 42 (2010): 125-153.

Price, Vincent, and Eun-Kyung Na. "Citizen Deliberation and Resistance to Framing Effects." In Annual Meeting of the American Association for Public Opinion Research, Portland, Oregon, 18-21. 2000.

Price, Vincent, Lilach Nir, and Joseph N. Cappella. "Framing Public Discussion of Gay Civil Unions.” Public Opinion Quarterly 69, no. 2 (2005): 179-212.

Rayside, David. Queer Inclusions, Continental Divisions: Public Recognition of Sexual Diversity in Canada and the United States. Toronto: University of Toronto Press, 2008. 
Reese, Stephen D. "Prologue - Framing Public Life: A Bridging Model for Media Research.” In Framing Public Life: Perspectives on Media and Our Understanding of the Social World, edited by Stephen D. Reese, Oscar H. Gandy, Jr., August E. Grant, 7-31. Mahwah, N.J.: Lawrence Erlbaum Associates, 2001.

Rubin, Gayle S. "Thinking Sex: Notes for a Radical Theory of the Politics of Sexuality." In Culture, Society, and Sexuality: A Reader, edited by Richard Parker and Peter Aggleton, 143-178. London: Routledge, 2007.

Sarsh, Bart. "“Disgusting' Noises, and 'Dangerous' Spaces: Tabloids, Sexualities, and Discourses of Perversion, Toronto, 1950-1962." MA research paper, University of Toronto, 2005.

Sarup, Madan. Identity, Culture and the Postmodern World. Edinburgh: Edinburgh University Press, 1996.

Scheufele, Dietram A. "Framing as a Theory of Media Effects," Journal of Communication 49, no. 1 (1999): 103-133.

Schudson, Michael. Why Democracies Need an Unlovable Press. Malden, MA: Polity, 2008.

Shapiro, Ivor. "Codes of Ethics.” Accessed May 25 ${ }^{\text {th }}$, 2019. https://j-source.ca/article/codes-ofethics/.

Shen, Fuyuan and Heidi Hatfield Edwards. "Economic Individualism, Humanitarianism, and Welfare Reform: A Value-Based Account of Framing Effects." Journal of Communication 55, no. 4 (2005): 795-809.

Shoemaker, Pamela J. et. al. "Readers as Gatekeepers of Online News: Brazil, China, and the United States.” Brazilian Journalism Research 6, no. 1 (2011): 55-77.

Silversides, Ann. AIDS Activist: Michael Lynch and the Politics of Community. Toronto: Between the Lines, 2003.

Skinner, David. "Alternative Media in Canada." The Canadian Encyclopedia. Article published February 07, 2006; Last Edited June 19, 2018. https://www.thecanadianencyclopedia.ca/en/article/alternative-media.

Smith, Miriam. "Framing Same-Sex Marriage in Canada and the United States: Goodridge, Halpern and the National Boundaries of Political Discourse." Social \& Legal Studies 16, no. 1 (2007): 5-26

Smith, Miriam. "Identity and Opportunity: The Lesbian and Gay Rights Movement.” In Queerly Canadian: An Introduction Reader in Sexuality Studies, edited by Maureen FitzGerald and Scott Rayter, 121-138. Toronto, Ontario: Canadian Scholars' Press Inc., 2012. 
Smith, Miriam. Lesbian and Gay Rights in Canada: Social Movements and Equality-Seeking, 1971-1995. Toronto: University of Toronto Press, 1999.

Stryker, Susan. "Transgender History, Homonormativity, and Disciplinarity." Radical History Review 2008, no. 100 (2008): 145-157.

Tadlock, Barry L., C. Ann Gordon, and Elizabeth Popp. "Framing the Issue of Same-Sex Marriage: Traditional Values Versus Equal Rights.” In The Politics of Same-Sex Marriage, edited by Craig A. Rimmerman and Clyde Wilcox, 193-214. Chicago: The University of Chicago Press, 2007.

Taras, David. Power and Betrayal in the Canadian Media. Peterborough, Ont.: Broadview Press, 1999.

Thompson, John B. The Media and Modernity: A Social Theory of the Media. Stanford, California: Stanford University Press, 1995.

Tremblay, Manon. "Introduction.” In Queer Mobilizations: Social Movement Activism and Canadian Public Policy, edited by Manon Tremblay, 3-41. Vancouver: UBC Press, 2016.

Tuchman, Gaye. Making News: a Study in the Construction of Reality. New York: Free Press, 1978.

Ward, Stephen J. A. The Invention of Journalism Ethics: The Path to Objectivity and Beyond. Montreal: McGill-Queen's University Press, 2015.

Warner, Michael. Publics and Counterpublics. New York: Zone Books, 2002.

Warner, Tom. Never Going Back: A History of Homosexual Activism in Canada. Toronto, Ont: University of Toronto Press, 2002.

Wessler, Hartmut and Rainer Freudenthaler. "Public Sphere.” Last modified January 11, 2018. https://www.oxfordbibliographies.com/view/document/obo-9780199756841/obo9780199756841-0030.xml\#firstMatch.

Winseck, Dwayne. Media and Internet Concentration in Canada Report 1984 - 2017. Canadian Media Concentration Research Project. December 11, 2018.

Young, Claire and Susan Boyd. "Losing the Feminist Voice? Debates on the Legal Recognition of Same Sex Partnerships in Canada.” Feminist Legal Studies 14, no. 2 (2006): 213-240. 


\section{Interviewees}

Clark, Campbell. Chief Political Writer, The Globe and Mail. In discussion with the author, October $23^{\text {rd }}, 2018$.

Galloway, Gloria. Former Staff Reporter, Parliamentary Reporter, The Globe and Mail. In discussion with the author, October $2^{\text {nd }}, 2018$.

Ibbitson, John. Staff Writer at Large, The Globe and Mail. In discussion with the author, September $28^{\text {th }}, 2018$.

Kinsman, Gary. Queer and Anti-Capitalist Activist, researcher. In discussion with the author, November $1^{\text {st }}, 2018$.

Marchildon, Gilles. Former Executive Director at Egale Canada. In discussion with the author, December $2^{\text {nd }}, 2018$.

McCaskell, Tim. Former member of The Body Politic, founding member of AIDS ACTION NOW!. In discussion with the author, October $24^{\text {th }}, 2018$.

Naumetz, Tim. Politics Report, iPolitics. In discussion with the author, November $16^{\text {th }}, 2018$.

Rayside, David. Activist and academic. In discussion with the author, October $12^{\text {th }}, 2018$.

Tibbetts, Janice. Journalism Instructor, Carleton University. In discussion with the author, October $29^{\text {th }}, 2018$.

Vallis, Mary. Journalism Instructor, Centennial College. In discussion with the author, January $18^{\text {th }}, 2019$.

Valpy, Michael. Retired journalist, Senior Fellow at Massey College. In discussion with the author, April 2019.

Warner, Tom. Gay rights activist, former Human Rights Commissioner. In discussion with the author, November $7^{\text {th }}, 2018$. 